\title{
Evolution of Pathological Staging and Histological Classification in Urological Malignancies
}

\author{
Ph.D. Thesis \\ Farkas Sükösd, M.D. \\ Department of Urology \\ University of Szeged
}

\begin{abstract}
University of Szeged Faculty of Medicine
Clinical Medical Sciences Doctoral School
\end{abstract}

Ph.D. Program: The Damage and Reconstructive Surgery of the External Genitalia Program director: Lajos Kemény M.D., Ph.D., D.Sc.

Supervisor: László Pajor M.D., Ph.D.

Szeged, Hungary

2016 


\section{List of publications}

I. Sükösd Farkas és Pajor László : A radikális cystectomiás minta teljes szövettani feldolgozásának módszere és költségkihatása Magyar Urológia | 2012 | 24. évfolyam 2. Szám Magyar Urológia.2012: „Legjobb klinikai tanulmány” prize.

II. Farkas Sükösd, Béla Iványi, László Pajor:Accurate Determination of the Pathological Stage with Gross Dissection Protocol for Radical Cystectomy Pathology \& Oncology Research July 2014, Volume 20, Issue 3, pp 677-685

IF: 1.855

III. Farkas Sükösd, Béla Iványi, László Pajor: What can be more prognostic than the pTNM category assessed on radical cystectomy specimens? Virchows Arch. 2015 Oct; 467(4):481-2. (Letter to editor.)

( IF: 2.627)

IV. István Sejben, Zoltán Szabó, Nándor Lukács, Márton Loránd, Farkas Sükösd, Gábor Cserni : Papillary renal cell carcinoma embedded in an oncocytoma: Case report of a rare combined tumour of the kidney. Can Urol Assoc J. 2013 JulAug;7(7-8):513-6.

IF: 1.92

\section{Lectures}

I. Sükösd Farkas, Kneif Mária, Buzogány István és Pajor László: Papilláris vesetumour in situ hibridizációs vizsgálata. Patológus Kongresszus, Gyula, 1998. augusztus 26-29.

II. Farkas Sükösd :Large blocks in prostate and bladder pathology 3rd Pannonia Congress of Pathology May 15-17, 2014, Bled, Slovenia

III. Farkas Sükösd, Béla Iványi, László Pajor Accurate Determination of the Pathological Stage with the Gross Dissection Protocol for Radical Cystectomy (GDPRC) in Daily Routine Diagnostics.BIT's $8^{\text {th }}$ Annual World Cancer Congress, May 15-17, 2015 Beijing, China 


\section{Table of contents}

I. Introduction 4

II. Objectives 5

III. Evolution of the staging system 5

III/1 General characteristics of the TNM system for urological tumours 5

$\begin{array}{lll}\mathrm{III} / 2 & \text { Kidney tumours } & 6\end{array}$

$\begin{array}{lll}\text { III/3 Bladder tumours } & 8\end{array}$

III/4 Accurate determination of the pathological stage of radical cystectomy $\begin{array}{ll}\text { specimens using an oriented cut-up protocol } & 9\end{array}$

$\begin{array}{lll}\text { III/5 Prostate tumours } & 19\end{array}$

$\begin{array}{lll}\text { III/6 Testicular tumours } & 22\end{array}$

$\begin{array}{lll}\text { III/7 Penile tumours } & 23\end{array}$

IV. Changes in histological classification $\quad 24$

$\begin{array}{lll}\text { IV/1 Kidney tumours } & 24\end{array}$

IV/2 The possibility for genetic classification in the case of renal tumours 31

$\begin{array}{lll}\text { IV/3 Bladder tumours } & 39\end{array}$

$\begin{array}{lll}\text { IV/4 Prostate tumours } & 40\end{array}$

$\begin{array}{lll}\text { IV/5 Testicular tumours } & 41\end{array}$

IV/6 Penile tumours 42

V. Results $\mathbf{4 2}$

V/1. The directions of evolution of the stage classification 43

V/2. The advantages of GDPRC in radical cystectomies 45

V/3 Incorporation of new scientific results provides the basis for changes in histological classification $\quad 46$

VI/4 Histological and genetic classification in the case $\begin{array}{ll}\text { of papillary renal tumour } & 47\end{array}$

$\begin{array}{lll}\text { VI/5 Summary of results } & 48\end{array}$

VI. Acknowledgements 49

VII. References $\quad \mathbf{5 0}$ 
"Any classification system is only as good as

the existing methodology in determining the extent of the local tumour."

Donald G. Skinner

\section{Introduction}

In clinical pathology, the main aim of a tumour examination is to obtain information for the further treatment of the patient and to determine its prognosis. The tumour stage and histological type are the most important histopathological parameters and they provide the basis for a comparison of data obtain for different centers and for the creation of homogeneous patient cohorts to be used for therapy development. Historically tumour staging and efforts to achieve uniform histological classification commenced half a century ago [1]. The relevant literature is growing and it is continuously being restructured. Consecutive staging and histological classification systems exhibit significant differences, and appear quite unstable for the practising physician. These constant changes seem to endanger comparability over consecutive classifications, as well as the formation of homogeneous patient cohorts of high case numbers. It is also open to question as to whether these constantly updated classifications constitute a developmental process, or are only reorganisations of knowledge necessitated by the most recent information. To date it seems that there is no clear answer to this question in the available literature.

The basis of pathological staging is the TNM system created by the joint effort of the Union Internationale Contre le Cancer (UICC) and the American Joint Committee on Cancer (AJCC). It is in practice modified every five years on average, and so far (i.e. since 1968) it has been altered seven times. It should be kept in mind that, although categories T, N and M have identical definitions in each edition (e.g. pT1, pT3a, N2), their meaning and content have often changed, shifted, been separated or merged, thus causing significant uncertainty in clinical practice. For example, pN2 in kidney cancer originally meant the localisation of lymph nodes involved, then their number and a few years later their size.

The standards in histological classification are set by the World Health Organisation (WHO), and are disseminated in the publications known in pathology as the "Blue Books". The individual tumour types are described in increasing details, which helps to enhance the precision of pathological diagnostics. It has become evident from 
these volumes that the primary driving force behind the renewal of histological classifications is recognition of different entities using ever newer methods. As a consequence, once again there is significant variation; however, the results of the use of an increasingly precise nomenclature are also evident even today. For example, sarcomatous kidney cancer, formerly an independent entity now means the undifferentiated forms of all types.

At the time of a decision regarding therapy or the introduction of new therapeutic procedures, it is well worth checking on the stability of the stage classification and histological subtype of the organ in question. If the classification (or some part of it) of a given organ is frequently changed, it is worth asking why this happens. One might ask, for instance, to what extent the frequent changes are due to statistical uncertainties or to methodical inadequacies.

\section{Objectives}

Our objective was to study the development of the two most important pathological factors required for the treatment of urological tumours, namely staging and histological typing, in order to obtain data to help devise more accurate procedures. We wished to identify those points where their application in daily diagnostic practice is the most problematic. Based on our knowledge investigations, two such areas were analysed in depth,

1. We wished to reduce the subjective component present in the pathological staging of radical cystectomies, and to this end we developed a cut-up protocol that minimises it.

2. We wished to examine the applicability of the genetically based classification of kidney tumours in the differential diagnostics of papillary kidney tumours.

\section{Evolution of the staging system}

\section{III/1 General characteristics of the TNM system for urological tumours}

In general, stages should take into account the anatomical dimensions of primary tumours, the status of lymph nodes and distant metastases. The objective of any staging system is to help clinicians in planning therapy and to obtain prognostic data, as well as to promote the improvement of therapeutic procedures and to permit the comparison of data originating from various treatment centres on a uniform basis. 
In 1954 the Union Internationale Contre le Cancer (UICC) established the Committee on Clinical Stage Classification and Applied Statistics, led by Dr. P. Denoix. The Committee formulated its recommendations for 23 organs by 1968. These recommendations constituted the basis of the first edition of TNM, which, however, did not include urological malignancies except for those of the penis. The second edition published in 1974, however, was already complete. In the first three editions, there were significant differences between preoperative (clinical) and postsurgical pathological stages. The latter was a considerably simplified version of the former, and also contained numerous inconsistencies. In the case of bladder tumours, for example, the preoperative classification of the second edition took microscopic evidence into account. Although this can be carried out using a TUR (Trans Urethral Resection) sample, the microscopic diagnosis of uterine or vaginal involvement, which is required for staging as pT4a, is surely infeasible. Cystectomy may be presumed, which, however, is a postoperative state in any case. At the same time, pathological stages themselves do not contain subgroups, which are often assessed by microscopic examination. However the separation of a pathological staging system from clinical ones gradually occurred.

\section{III/2 Kidney tumour}

The first staging system was created by Flock and Kadesky in 1958, based on macroscopic surgical and pathological observations. However, a five-year follow-up of 353 cases did not reveal any significant differences between stage 1 and stage 2 [2]. In 1963 Robson improved the system, which became widely accepted after. In the course of the surgical and pathological evaluation of 88 operations including lymphadenectomy, Robson established that prognosis depended on histological grade, the infiltration of the macroscopically visible veins; the involvement of the surrounding structures the presence of metastases in lymph nodes and distant organs (Table 1).

\begin{tabular}{|l|l|}
\hline Stadium & Description \\
\hline I & $\begin{array}{l}\text { Tumour is confined to the kidney. Perinephric fat, renal vein and regional nodes show } \\
\text { no evidence of cancer. }\end{array}$ \\
\hline II & $\begin{array}{l}\text { Tumour involves the perinephric fat, but is confined within the Gerota's fascia. Renal } \\
\text { vein and regional nodes show no evidence of cancer. }\end{array}$ \\
\hline III & $\begin{array}{l}\text { The tumour involves the renal vein or regional nodes with or without involvement of } \\
\text { vena cava or perinephric fat. }\end{array}$ \\
\hline IV & $\begin{array}{l}\text { Distant metastasis secondary to renal cell carcinoma present on admission. Or, } \\
\text { histologic involvement of visceral structures by tumour. }\end{array}$ \\
\hline
\end{tabular}

Table 1. Robson's tumour stage classification system 
Robson's classification allowed a more precisely classified than with former systems. However, just four categories were available, hindering the possibility of a more precise differentiation. Despite this, it was more widely used at that time than first three TNM systems.

The first TNM classification did not include the kidney. The second considered the postoperative pathological stage to be identical with the preoperative clinical stage, even though the vascular propagation of the parenchyma or arteriographically verifiable parenchyma continuity cannot be subjected to a histological analysis. Similarly, lymph node fixation in the N3 category can only be assessed surgically. The M category was not included in the second edition. The involvement of the neighbouring organ was classified as the T4 category in the second edition. This was far seeing in the case of the adrenal gland, whereas it was treated as a lower category in next four editions and returned to its former position only in the most recent editions. The third edition included a separate stage defined "V" category that indicated vascular involvement, which appears to have been influenced by Robson's classification (Table 2).

\begin{tabular}{|l|l|}
\hline V0 & Veins do not contain a tumour \\
\hline V1 & Renal vein contains a tumour \\
\hline V2 & Vena cava contains a tumour \\
\hline VX & Veins cannot be assessed \\
\hline
\end{tabular}

Table 2. The third edition of TNM included a separate "V" category that indicated vascular involvement

Categories based on tumour size were first introduced in the third edition. A low size range was reserved for T1 stage, just for incidentally recognised tumours. As regards lymph nodes, the stage-determining role of laterality was withdrawn and classification was based not just on the size but also the number of nodes. The M stage was introduced and it has remained unaltered to this day. The fourth edition abolished "V" category and, following the general TNM concept, merged it into the T category. This also meant an integration of the Robson system into the TNM nomenclature. At that time subcategories were introduced, opening up the possibility of a more refined classification. The involvement of the adrenal glands was still not clarified, but it was treated as a lower stage (T3a) than in the second edition. The fifth edition introduced a tumour diameter of 7 $\mathrm{cm}$ as the cut-off between the $\mathrm{T} 1$ and $\mathrm{T} 2$ categories, which has, been retained. The N3 category was abolished and the rest was left unchanged. In the sixth edition, tumours with 
diameters less than $7 \mathrm{~cm}$ were classified into subgroups. In the seventh edition, tumours larger than $7 \mathrm{~cm}$ were also divided into subgroups, and a tumour spreading to the adrenal gland in a continuous fashion was classified as pT4.

\section{III/3 Bladder tumours}

The foundations of the stage classification of bladder cancers were laid down by Jewett and Strong [3]. Between 1919 and 1944, they analysed the autopsies of 127 patients who died as a consequence of infiltrating tumours. They found a correlation among metastasizing tumours, a spread in lymphatic vessels, fixation to surrounding structures and tumour infiltration depth. Three groups were defined, namely A: submucosal infiltration, B: muscular infiltration, and C: perivesical fixation (Figure 1). They showed that the number of lymph nodes involved and the probability of distant metastases and of fixation increase with muscular infiltration and that these are even higher when extra organic propagation occurs. They found that submucosal spread is potentially curable, whereas only a quarter of fixed tumours are successfully treated. This publication clarified the position of the efferent lymphatic vessels of the bladder relative to the peritoneum and the abdominal wall, and identified the organs that most often harbour distant metastases (non regional lymph nodes, liver, lungs, vertebral column) [3].

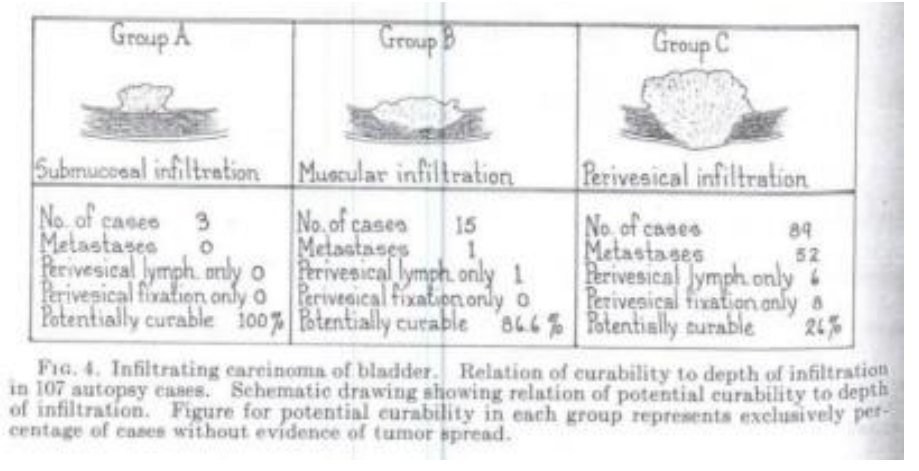

Figure 1. The stage classification by Jewett and Strong from the original publication [3]

In 1952, based on 80 cases, Jewett further refined this classification system: he divided muscular involvement into B1 (superficially invasive) and B2 (deeply invasive) groups [4]. The soundness of this decision is still being debated, and Jewett himself had doubts at one point. In fact, in 1978, he wrote: "It seems probable that our arbitrary dividing line drawn 30 years ago at the halfway level to separate B1 (pT2a) from B2 (pT2b) tumours was too superficial" [5]. Nevertheless, the division is still valid today. The work of Jewett and Strong was supplemented by Marshall, who introduced stage 0 and in situ carcinoma, and separated tumours not infiltrating the lamina propria. However, he also included those cases where the presence of neoplasia was confirmed in 
a biopsy within 30 days, even though it was not observed at the time of the examination [6].

The classification proposed by Jewett, Strong and Marshall was largely incorporated into the TNM system. It translated the letter symbols into its own nomenclature, and supplemented the pathological classification with a clinical interpretation. The entity known today as pTa corresponds to pTis in the second edition; it is not mentioned in the third edition, and is again in continuous use starting from the fourth edition. Consequently, it is from that point on that the meaning of pTis as a "flat" tumour can be considered well established. Actually there were no more modifications at thet point in the later and third editions. Subepithelial connective tissue infiltration, once separated by Jewett, is still in use under the name of pT1. In the fourth edition, perivesical adipose tissue infiltration was first divided into microscopic and macroscopic categories. In the case of lymph nodes, the size of the metastasis has become relevant, like in other organs. The fifth edition has the classification used today, the only difference being the consideration of the number and localisation of the lymph nodes involved.

\section{III/4 Accurate determination of the pathological stage of radical cystectomy specimens using an oriented cut-up protocol}

The stages assessed in cystectomy reveals a considerable variability in the publications [7-21] (Table 3). We think that, behind this heterogeneity there is an insufficient standardisation of the pathological processing of radical cystectomy specimens. As regards the importance of the pathological reports [22, 23], a Gross Dissection Protocol for Radical Cystectomy (GDPRC) samples was developed and introduced into the daily routine practice of our Institute. Our main intention was to further improve the European recommendation [24] by utilising the potential of the commercially available macroblock technique. 


\begin{tabular}{|c|c|c|c|c|c|c|c|c|c|c|c|c|c|c|c|c|c|c|c|c|c|c|c|c|c|c|c|c|c|c|}
\hline 递 & 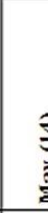 & שُ & & 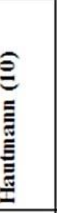 & 氞 & & & $\frac{8}{6}$ & 6 & & 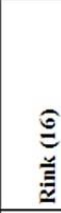 & & 尺 & & 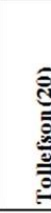 & & की & & $\begin{array}{l}6 \\
0 \\
0\end{array}$ & & ב & : & & 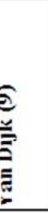 & 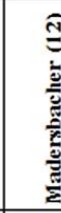 & עִ & $\begin{array}{ll}2 \\
5\end{array}$ & 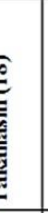 & 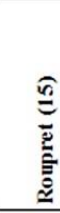 & \\
\hline Interval & \begin{tabular}{|l|l|}
1999. \\
\end{tabular} & & $1958-2$ & -2009 & $1958-20$ & & 1959 & 2004 & \begin{tabular}{|l|l} 
\\
\end{tabular} & & 1999.20 & & 19912 & & $1950-2$ & & \begin{tabular}{|l|l|} 
& 1971.15 \\
\end{tabular} & & $1995-2$. & & 1958 - & & 1999. & & $1955-2$ & & $\mid$\begin{tabular}{|l|}
$\mid 1991.2$ \\
\end{tabular} & & $1990-20$ & \\
\hline Location & Germ & & $\begin{array}{r}\text { SI } \\
\text { Germ }\end{array}$ & & $\begin{array}{r}51 \\
\text { Germs }\end{array}$ & & $\begin{array}{c}\text { Int. } \\
\text { nats } \\
\text { notion }\end{array}$ & $\begin{array}{l}11 \\
\text { cro } \\
\text { onsal }\end{array}$ & $\begin{array}{c}M \\
\text { Inte } \\
\text { notio }\end{array}$ & & $\begin{array}{c}\text { MI } \\
\text { inter } \\
\text { nostion }\end{array}$ & & $\begin{array}{l}\text { sl } \\
\text { us }\end{array}$ & & $\begin{array}{l}\text { s1 } \\
\text { us }\end{array}$ & & $\begin{array}{c}\text { s1 } \\
\text { usa }\end{array}$ & & $\begin{array}{c}\text { s1 } \\
\text { Sposin }\end{array}$ & & $\begin{array}{r}51 \\
5 p 0\end{array}$ & & $\begin{array}{c}\mathrm{m} \\
\text { The } \\
\text { Nethe }\end{array}$ & & $\begin{array}{r}\text { S1 } \\
\text { Switzer }\end{array}$ & & & & France & \\
\hline $\begin{array}{l}\text { No. of } \\
\text { cases }\end{array}$ & 24 & 03 & 110 & & 605 & & 44 & 62 & 32 & & 433 & & 135 & & 117 & & 105 & & 111 & & 42 & & 37 & & 50 & & 51 & & 475 & \\
\hline & no. & $\%$ & \begin{tabular}{|l|} 
no. \\
\end{tabular} & $\%$ & \begin{tabular}{|l|} 
no. \\
\end{tabular} & $\%$ & no. & $\%$ & no. & $\%$ & no. & $\%$ & no. & $\%$ & no. & $\%$ & no. & $\%$ & no. & $\%$ & no. & $\%$ & no. & $\%$ & no. & $\%$ & no. & $\%$ & no. & $\%$ \\
\hline $\mathrm{pT} 0$ & 132 & 5.5 & 208 & 18.9 & 10 & & \begin{tabular}{|l|}
72 \\
\end{tabular} & 2 & & & & & & & 69 & 59 & 66 & 6 & \begin{tabular}{l|l}
141 & 1 \\
\end{tabular} & 12.7 & 43 & 10.2 & \begin{tabular}{|l|}
62 \\
\end{tabular} & 17 & & & & & \begin{tabular}{|l|}
258 \\
\end{tabular} & 5.4 \\
\hline pI & 77 & \begin{tabular}{|l|}
3.2 \\
\end{tabular} & 30 & \begin{tabular}{|l|}
2.72 \\
\end{tabular} & & & \begin{tabular}{|l|l|}
111 \\
\end{tabular} & & & & & & & & 38 & 3.2 & 42 & 4 & & & & & & & & & & & & \\
\hline pTis & 104 & 43 & \begin{tabular}{|l|}
133 \\
\end{tabular} & 12.09 & & & 124 & 3 & \begin{tabular}{|l|l|}
117 \\
\end{tabular} & 3.64 & & & & & \begin{tabular}{|l|l|}
237 \\
\end{tabular} & 20 & \begin{tabular}{|l|l|}
100 \\
\end{tabular} & 9 & & & & & \begin{tabular}{|l|}
17 \\
\end{tabular} & 4.5 & & & & & & \\
\hline $\mathrm{pTl}$ & \begin{tabular}{|l|}
359 \\
\end{tabular} & 16.2 & \begin{tabular}{|l|}
127 \\
\end{tabular} & 11.54 & \begin{tabular}{|l|l|}
126 & 2 \\
\end{tabular} & 20.8 & 765 & 17 & & & \begin{tabular}{|l|l}
585 & 1 \\
\end{tabular} & 13.5 & & & 194 & 17 & \begin{tabular}{|l|l|}
194 \\
\end{tabular} & 18 & & & & & 20 & 53 & 77 & 15 & & & & \\
\hline $\mathrm{pT} 2$ & 657 & 27.4 & 240 & 21.8 & \begin{tabular}{|l|l|}
118 & 1 \\
\end{tabular} & 19.5 & 1035 & 23 & & & 1042 & 24 & 311 & 23 & 270 & 23 & 94 & 3 & & & & & & & 151 & 30 & 156 & 30.2 & & \\
\hline $\mathrm{p}$ T3 & 796 & 33.1 & \begin{tabular}{|l|}
256 \\
\end{tabular} & 23.26 & \begin{tabular}{|l|}
269 \\
\end{tabular} & 44.5 & 1878 & 42 & & & \begin{tabular}{|l|l}
1371 & 3 \\
\end{tabular} & 31.6 & & & & & 233 & 21 & & & & & & & 184 & 36 & 152 & 29.4 & & \\
\hline $\mathrm{pT} 4$ & 248 & 103 & \begin{tabular}{|l|}
106 \\
\end{tabular} & \begin{tabular}{l|l|}
9.62 \\
\end{tabular} & \begin{tabular}{|l|}
10.1 \\
\end{tabular} & 61 & 477 & 11 & & & \begin{tabular}{|l|l|}
563 & \\
\end{tabular} & 13 & & & & & 79 & & & & & & & & 78 & 16 & \begin{tabular}{|l|}
90 \\
\end{tabular} & 17.4 & & \\
\hline
\end{tabular}

Table 3. 15,586 stage related data taken from more than 27, 397 cystectomies, reported in 15 international publications. Here, we focused on credibility. Only those papers were considered which presented more than 350 cases, demonstrated the practice, and all of the stages were described including pT0

The incidence of tumours of the bladder has been on the increase over the past two decades, and this type of tumour is a problem of increasing importance world-wide. In 2002, 357,000 new cases were registered globally by the WHO, making bladder cancer the fifth most common tumour type in men and the eighth in women [25]. The treatment for advanced bladder tumours (pT2-4a) is radical cystectomy. In Hungary, for instance, 172 operations of this type were performed in 2010.

The most important information for clinical decisions regarding advanced bladder cancer and for the determination of its prognosis is the clinical stage of the tumour. The majority of these tumours are of urothelial origin and are poorly differentiated, which means that they cannot be classified on the basis of these characteristics [22]. In nearly half of the cases, the clinical stage does not match the post-surgical classification based on histopathological examination [26] because physical examination and imaging techniques are of limited value for the establishment of the clinical stage. The typical accuracy of CT scans is only $54.9 \%$. In $39 \%$ of the cases it gives larger dimensions and in $6.1 \%$ of the cases gives smaller dimensions than those confirmed by histology [27]; and, similarly, CT is not adequate for the evaluation of either muscle invasion [28] or spread to the perivesical areas and into the lymph nodes [29]. Recent technical innovations have not improved this situation. Neither has the application of fluoro-2-deoxyglucose PET/CT significantly enhanced the precision [30]. Overall, clinical and pathological stages coincide only in about one-third of the cases [31]. It has been established that the 
pathological examination is decisive for the design of postoperative therapy and for prognosis $[16,22,23]$. The most important step of the pathological processing of the sample to be studied is the selection of the areas to be processed for microscopic examination, because these areas will represent the entire tumour, and these will be studied in detail by microscopy, immunhistochemistry or pathological consultation.

Microscopic examinations go back much further than the guidelines for the cut-up of surgical samples. Consequently, their system of criteria is not as developed as that of the latter. The first set of guidelines regarding the cut-up out of a urinary bladder that was removed because of cancer was issued 55 years ago [32]. Several manuals of ever improving quality were published before the latest one considered which is to represent the standard technique [24]. All of these recommendations are consistent in that they enumerate the areas of the specimens that need to be cut out, but do not elaborate on the mode of cut-up, even though they describe two different procedures for the dissection of the specimen in detail. The mode of cut-up and the positioning in microscopic sections of certain organs such as the uterus, the cervix, the fallopian tube, the appendix and the skin have been meticulously regulated. The main objective of all these guidelines is to reduce the subjectivity in the cut-up procedure that come from the different detections of the pathologist.

Here we describe in detail the cut-up, embedding and microscopic evaluation steps of the processing of radical cystectomy samples as well as the results obtained, and we will also mention the financial and workload aspects of the procedure.

From 2008 to the first quarter of 2012, 138 radical cystectomies were performed at the Department of Urology of the University of Szeged. These samples were histologically processed as a whole using macroblocks. They were taken from 99 men and 39 women. The average age was 62.3 years; that of men was 64 years (range: 41-76), whereas that of women was 60.6 years (range: 49-71).

\section{Processing of surgical samples}

The processing and histological evaluation of cystectomy specimens is described in the publication [33]. In short, the samples were fixed in $10 \%$ formalin without dissection, for a minimum of three days. The cut-up procedure of the cystectomy material is schematically presented in Fig. 2. An anterior orientational incision was made from the urethral orifice to the bladder dome (Fig. 2). Male and female bladders were further dissected by applying different steps: 

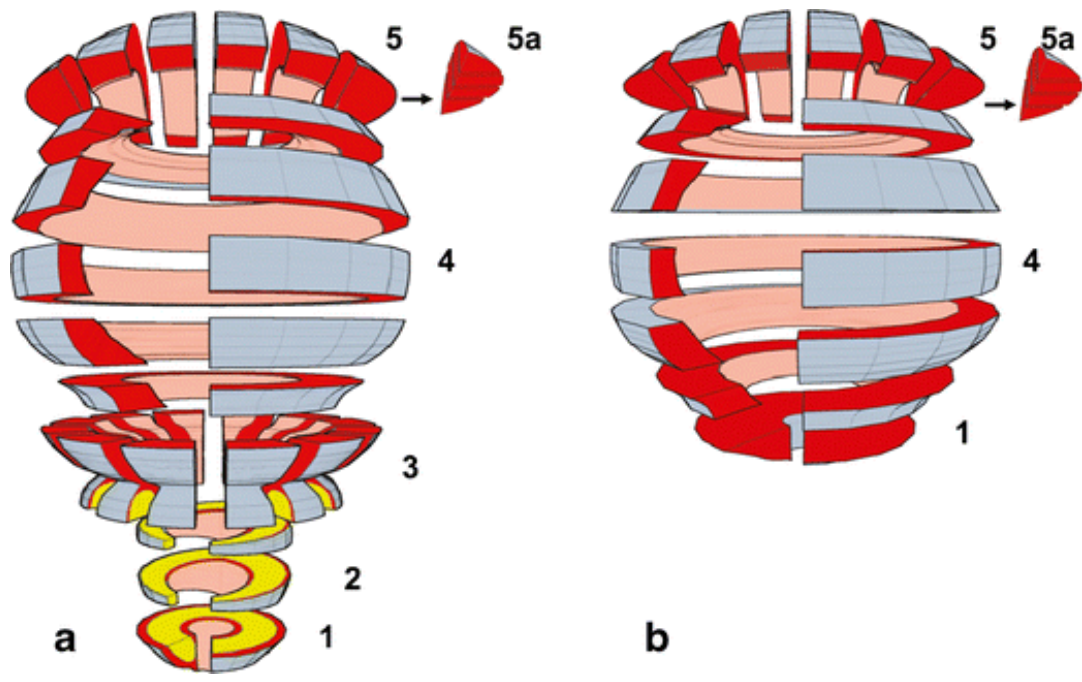

Figure 2. The cut-up procedure of radical cystectomy (a: male b: female)

\section{Cut-up steps of the male urinary bladder}

1. The preparation of an urethral resection line

2. A wedge-shaped section of the prostate

3. The preparation of a bladder-prostate basal block including the bladder base and the prostate base

4. The preparation of 12 radial sections of the basal block

5. The preparation of cross-sections above the basal block

6. The processing of the bladder dome in sagittal parallel levels

7. The embedding of the seminal vesicle.

Cut-up steps of the female urinary bladder

1. The uterus complete with its bilateral appendages and the antero-superior area of the vaginal wall were separated from the bladder

2. A cross-section also containing the urethral resection level was prepared for further study.

3. The bladder was embedded in the form of cross-sections.

4. The processing of the bladder dome was identical with the cut-up steps of the male bladder.

5. The uterine portio and the vaginal stump were embedded in parallel sections after separation from the cervix.

6. The entire area of the uterine cervix in contact with the urinary bladder below the peritoneal junction was embedded in cross-sections.

7. The uterine corpus and the bilateral appendages were prepared for examination using the relevant procedural protocol [34]. 
The GDPRC was implemented in a non-rigorous way. The most frequent modification was that of visualisation, for both cutting levels, of the lesion selected as important on the cutting surface. Regional lymph nodes were embedded as a whole and larger ones were halved.

Stages were determined with the AJCC/UICC TNM system, which was revised in 2002 [23]. The frequencies of the individual stages were then expressed in percentages. Differences were evaluated using the one-sample z-test. ( $p$ value $<0.05$ )

The data on stages and sizes

The GDPRC was introduced as a daily routine processing procedure at the Institute of Pathology of the University of Szeged in 2008 and, in the case of each radical cystectomy specimen, it has been maintained ever since.

The results are shown in Table 4. Obturator lymph nodes were removed in 126 cases $(91.3 \%)$. In two cases the lymph nodes formed conglomerates that were not taken into account.

\begin{tabular}{|l|l|l|l|l|l|l|l|}
\hline & \multicolumn{1}{|c|}{ pT0 } & pTa & pTis & pT1 & pT2 & pT3 & pT4 \\
\hline No. of cases (\%) & $\mathbf{1 2}(8.7)$ & $\mathbf{1}(0.7)$ & $\mathbf{4}(2.9)$ & $\mathbf{2 1}(15.2)$ & $\mathbf{2 9}(21)$ & $\mathbf{4 8}(34.8)$ & $\mathbf{2 3}(16.7)$ \\
\hline Total no. of lymph nodes & 240 & 13 & 64 & 398 & 517 & 840 & 327 \\
\hline Average no. of lymph nodes & 20 & 13 & 16 & 21 & 39.4 & 39 & 29.5 \\
\hline $\begin{array}{l}\text { No. of metastatic lymph nodes } \\
\text { (percentage of total no. of lymph } \\
\text { nodes in category) }\end{array}$ & $13(5.4)$ & 0 & 0 & $2(0.5)$ & $18(3.4)$ & $123(14.7)$ & $58(17.7)$ \\
\hline
\end{tabular}

Table 4 . The stage distribution in 138 consecutive radical cystectomy assessments with the GDPRC

The average sizes of the 124 preparations were: supero-inferior $101.6 \mathrm{~mm}$ (range: 40-170); medio-lateral $92.7 \mathrm{~mm}$ (range: 40-140); antero-posterior $75.7 \mathrm{~mm}$ (range:35130). The average mass of the 119 specimens was $308 \mathrm{~g}$ (range: 46-680).

Using the macroblock technique, we were able to prepare 7-mm-thick bladder wall sections and prostate sections with a maximal thickness of $5 \mathrm{~mm}$.

\section{Material consumption and costs}

On average, 9.2 macroblocks and 14 standard blocks were used for our processing of the bladder and the prostate. In the case of radical cystectomy of male patients, an average of 9.8 macroblocks and 16.3 standard blocks were prepared. In the case of cystectomy of female patients, 8.8 macroblocks and 9.6 standard blocks were applied. 
The cost of the materials used for preparation of a macrosection was $€ 1.8$, whereas that of a standard histological section was $€ 0.25$. The average cost of the materials and chemicals used for processing using to the GDPRC of a male radical cystectomy specimen was $€ 21.8$ and that of a female one, $€ 18.2$. A necessary one-time investment was that of a macro head for the microtome. Cut-ups with photographic documentation took about two hours per case and the microscopic examination took further two hours of the pathologist's time.

The cut-up procedure of the urinary bladder has remained basically unchanged since the publication of the first guidelines 55 years ago; it has only been supplemented by a list of the anatomical structures deemed important to examine. These guidelines leave it to the pathologists to select those of the listed areas that may be expected to contain microscopic lesions [24]. This method of selection, however, is only of limited value, especially in the case of formalin-fixed samples [35]. Due to the recognition of the significance of the additional information to be gained for clinical use, the need for a more precise determination of the pathological processing technique of cystectomy specimens arose fifteen years ago [36]. The first trial with a relatively large case number was conducted by Soto et al. They inflated the bladder with celluloid, and applied a lengthy procedure only to 45 radical cystectomy preparations that could be examined as a whole over the fifteen-year period [35]. The most commonly applied method is the stepsectioning, which begins with the urinary bladder being opened through the urethra by a cut along the anterior wall, stretched on a corkboard and fixed. The bladder and the connected organs are next cut into 5-10 mm horizontal sections, which are embedded in a topographically registered block. The overview of the often very numerous microscopic sections of course necessitates graphic registration. A similar technique is one that has been the only method recommended for application as a routine evaluation procedure, in which the sample by an incomplete frontal and a subsequent sagittal cut results in a specimen consisting of four quadrants forming an X shape. The 50-100 blocks per case were grouped by quadrants, marked by the letters of the alphabet and located on a photograph or drawing of a specimen [36]. However, the reconstruction with standard blocks and the dimensions of the tumour cannot be accurately determined due to the distortion of size and the difficulties of orientation. In addition, it is not suitable for the examination of relatively large tumours prolapsing into the lumen, because these cannot be laid out without destroying them. Owing to this, the same is true for the cut-up guidelines currently in use. All in all, the step-sectioning method may only address one or two special targeted questions for research purposes. Dissection in a single sagittal 
section led medially through the specimen may be demonstrative and it is used in textbooks and publications to support the conclusions they have reached.

Today, the accepted routine pathological processing of cystoprostatectomy samples is summed up in the pathological handbook edited by Rosai and Ackerman. This manual represents the most widely accepted international recommendations. It provides a list containing the anatomical locations to be examined, and two drawings to aid dissection; the latter also show some of the locations to be examined, given in the list. When only minimal cut-ups are considered, at least 25 have to be made on a male bladder, and only three (!) of these will come from the tumour [37].

With the GDPRC we perform the examination on macrosections in a standardized mode which eliminates subjectivity inherent with the cut-up procedure described above. This is the most critical step of pathological processing and we adapted it to the conditions of daily routine, while keeping the possibility of intervention open. Obvious advantages of the GDPRC are the following:

This technology allows an unambiguous definition of category pTO

Values between $6 \%$ and $41 \%$ proportion of pT0 resections have been reported as not negligible $[16,38]$. What is more, due to the increasingly effective neoadjuvant therapies and the application of extended TURB, an increase in the number of cases is expected [39]. In the absence of suspicious macroscopic signs or data regarding the localisation of earlier interventions, there is no guidance on how to preforms the cut-ups. If the first cut-ups displaying tumour negativity were made in a non-oriented fashion, subsequent cuttings can only be incidental, and no guidance is given for their mode, extent or number. The papers investigating the clinical significance of pT0 sought to verify tumour negativity by taking random cut-ups [40]. The heterogeneity of pathological processing may be a significant factor in the standard deviation of the frequency of pT0 of published data. In the course of implementing the GDPRC, only those resections were classed as pT0 resections where the granulomatous area and the hemosiderin deposition indicative of the earlier intervention were observable and the entire preparation appeared tumour-free.

Subcategories of category pT2 can be precisely determined

Recently the usefulness of pT2 subcategories has become the focus of intensive debate. The division of muscle invasive tumours into internal and external layer involvement was based on Jewett's experience of autopsies of 107 patients who died from bladder cancer. The TNM system has also adopted this classification [41]. In contrast, Cheng et al. identified tumour size rather than infiltration depth as a prognostic marker, 
and supported their conclusion with numerous references [42]. In the course of follow-ups 123 muscle invasive tumours, American researchers failed to find any difference among subcategories of various infiltration depths, and hence suggested the simplification of the AJCC's classification based on the same principles; in other words, they abolished subcategories [43]. A recent international study, however, found the TNM system feasible, based on 565 cases [44]. The settling of the debate is made more difficult by the fact that after formalin fixation, aggressively infiltrating tumours exhibiting unicellular and tentacular spread which cannot be seen during naked eye examination or by palpation. Also, current imaging techniques do not offer any better resolutions than the microscopic ones. All these things can be overcome with the GDPRC, where the simultaneous preservation of the localisation and dimensions of the infiltrating area as well as its relationships with the surrounding tissues of tumour can be tested.

The category pT3a can be precisely identified.

The cut-ups for examination of microscopic progression beyond the bladder using the naked eye can only be done theoretically. All these circumstances may have contributed to the numerous reports of the failure to find differences between pT2 and pT3a [45]. The determination of the stage as to whether it is localised to the organ or spreading extravesically is also essential for prognosis and the planning of adjuvant therapy [46]. The validity of the subcategorisation of stage pT3 has been verified on the basis of a large number of cases $(n=2388)$, and this supports the usefulness of the currently used TNM system [45]. The GDPRC enables the identification and localisation of extravesical spread and measurement of its dimensions.

The category pT4a and prostate infiltration can be assessed precisely

The infiltration of dense prostatic tissue (pT4a) after formalin fixation is usually invisible to the naked eye. The route of spreading can occur (i) by breaking through the entire thickness of the bladder wall, or (ii) via the urethra. This point has some prognostic significance [47]. There is, however, no advice given on the method of the examination of prostate infiltration. Donat et al. studied three specimens cut to 3-mm-thick sagittal sections [47]. In this way, the urethra can be represented in only one or two cutting surfaces, whereas the urethra may not just be a route of infiltration but also a primary tumour site. The other possibility is the separation of the bladder and prostate. In this case both organs are dissected according to the protocol corresponding to the primary cancer of the given organ [48]. Our approach offers the possibility of microscopically studying both organs in one section. The 12 radial cut-ups of the bladder-prostate basal block not only preserve the relationship between the two organs, but 3D measurements and the 
circumferential resection distance can also be determined. This is important because it concerns the nearest resection edge. Our approach allows an extensive examination of the bladder neck as well.

\section{Processing of prostate and urethra}

The entire prostate tissue below the bladder-prostate basal block was studied in macrosections, in compliance with the current recommendation [49]. However, since the prostatic urethra runs in an anteriorly open angle, the cross section plane of the urethral resection margin and the plane of the basal block are not parallel but form a triangular section. (The reason why this does not occur in prostatectomy specimens is that the urethral resection line is not taken into account during the preparation of either the apex or the base, because it is not our intention to get complete cross-sections of this part.) The orifices open antero-medially from the vertical axis due to the physiological anteflexion of the urethra. In order to retain all surgical edge markings in the sections, further cuttings were also performed at an angle. In the case of prostate tumours, the infero-superior size was estimated from the slide thickness as half of the maximal thickness of the triangular block. Our approach permits the extensive examination of the bladder neck area, the proximal part of the urethra and periurethral tissue. In the case of urethral stump involvement, the distance from the resection margin was assessed from sagittal sections made after recovery from the block by melting.

\section{Comparison of the Stage Distribution Assessed by the GDPRC with the Literature}

The incidences of the pathological stages of cystectomies exhibit significant differences even within the same geographical region and time interval, even when the tests performed prior to cystectomy and the surgical indications are practically identical. Nevertheless, the incidence determined on the basis of a large number of cases must reflect the actual incidence. We therefore carried out determinations by using the data on 15,586 stages of 27,394 cystectomies presented in 15 publications from the period between 1971 and 2010 [5, 9-22]. Here, we just concentrated on credibility. We reviewed those papers that described over 350 cases, demonstrated the practice, and each category was present, including pT0. Furthermore, the percentages were also given along with numeric data for each category. (Blank spaces are shown where data were combined in the table.) We also created a summarised group from each category and counted the average frequency (see Table 3 and 4 and graphically on Figure 3). 


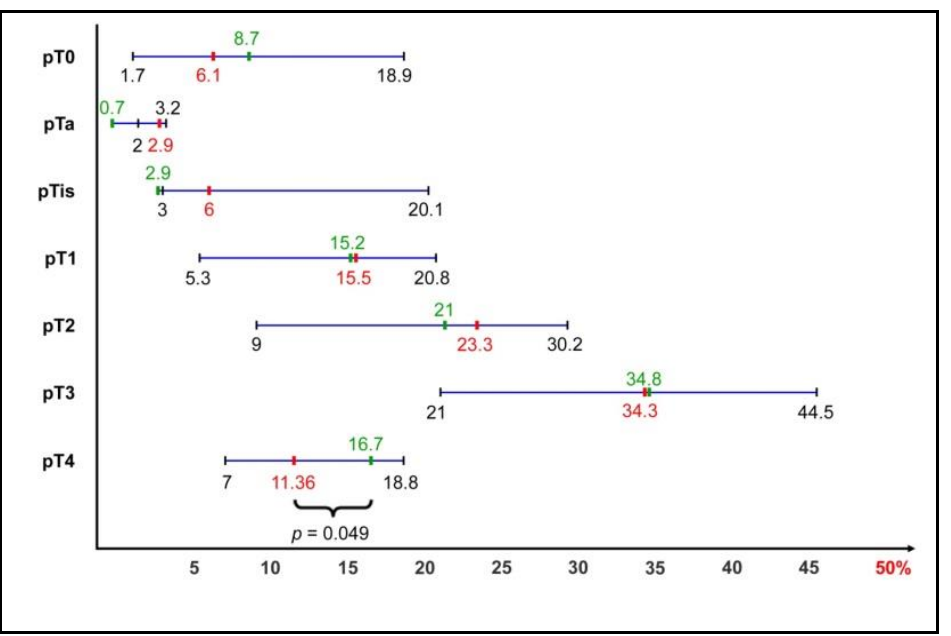

Figure 3. Standard deviation of 15,586 staged cases taken from the literature. The values in red show the average frequency and the values in green show the results with the GDPRC. For pT4, the difference is significant.

The relatively small number of cases evaluated with the GDPRC quite accurately reflects the statistical data based on a lower number of cases. The differences observed are due to our more precise approach: the case numbers in the pTis-pT2 groups were smaller, while those in groups pT3 and pT4 were greater. With pT4, the difference was significant $(11.36 \%$ vs. $16.6 \%, \mathrm{p}=0.049)$. We think that the more frequent occurrence of cases in the highest stage may provide a partial explanation for the generally bad prognosis of cystectomies.

The incidence of pT0 among the cases we studied was slightly higher than the average of the published data $(8.7 \%$ vs. $6.1 \%)$. The reason for this may be that the histological examination of preoperative TUR cannot provide a reliable evaluation of the completeness of tumour removal, and the resolution of imaging techniques is insuffitient in cases of small tumours. The surgical indications for this stage are therefore more uncertain, and are unsuitable for a good comparison.

The sample dissected using the GDPRC also allows the evaluation of other possibilities

The GDPRC allows as a part of daily routine the assessment of further prognostic factors such as:

1. The three-dimensional measurement of tumour dimensions

2. The representation of the full heterogeneity

3. The mapping of the infiltration pattern

4. Microscopic measurement of the distance and the extension of the circumferential resection line

5. The better identification able of vascular and perineural infiltrations

6. The determination of the associated urothelial dysplasia/in situ carcinoma. 


\section{Limitations of the GDPRC}

The GDPRC is more labour intensive and more expensive than the protocols used today. Current processing requires cutting into 25 standard cassettes, and this means only three standard blocks from the tumour and one from the surrounding mucosa. Hence the estimated cost is at least $€ 6.25$ ( $25 \times € 0.25=€ 6.25)$. The amount of materials used by the GDPRC for male bladders is three and a half times more and for female bladders, three times more.

Macrosection preparation requires a lot of practice, but the majority of the technical staff has already gained the necessary experience in the course of processing other organs, and they are capable of cutting 4-6 micrometre sections. Staining and the immunohistochemical processing of macrosections have not yet been automated. The GDPRC is especially labour intensive for pathologists.

The 7-mm-thick slides placed in macroblocks using the GDPRC technique as part of the routine pathological procedure is a reasonable compromise because we do not need to inflate the bladder before fixation, or to submit it to special preparative procedures under clinical conditions.

The GDPRC is not suitable for the processing of atypically resected material.

In spite of the unparalleled development of diagnostic and therapeutic devices, the survival rate of patients undergoing radical cystectomy has not improved in the past forty years. Their five-year survival rate continues to be barely more than 50\% [50]. In order to improve the pathological examination that determines the post-operative therapy, we applied macroblock techniques to minimise subjective factors affecting cut-ups in daily routine. This may be required not just for the pathological examination and for the comparability offered by the rapidly developing imaging procedures, but also for the determination of the effectiveness of locally instilled, molecularly targeted therapies, the introduction of which is expected in the near future.

\section{III/5 Prostate tumours}

The first prostate staging system was published in 1956 by Whitmore. He devised four groups; namely A, incidentally recognised, not palpable; B, palpable and localised to the organ; C, spreading outside the prostate but not metastasizing; D, metastatic tumour [51]. This system was further refined by Jewett with the introduction of subgroups, creating a pathological approach that has a prognostic potential. In the Whitmore-Jewett system, also known as the ABCD system, a localised tumour might be focal (A1) or 
diffuse (A2). In B1, the tumour involved not more than one lobe, whereas in B2, it was more, but it did not spread beyond the capsule. C1 stage tumours cause minimal invasion, and C2 cause extensive extracapsular, ureteral or urethral obstruction. Due to its ready applicability, the Whitmore-Jewett system gained wide use in the United States, but it was not appropriate for the description of a more complex process. About $25 \%$ of patients with a tumour extension corresponding to stage B already have nodal metastases, which places them into the D1 category; however, D1 itself contains no information regarding the tumour size or extent. Neither did the determination of extension relative to the lobes - a subject of continuous debate to this day - permit accurate usage. The demand for differentiation in terms of size was already formulated at that time.

The first edition of TNM did not include the prostate, or any other urological malignancies. The classification given in the second edition was not widely accepted. The third edition essentially adopted the Whitmore-Jewett classification, but applying the TNM designations (Table 5).

\begin{tabular}{|c|c|c|}
\hline $\begin{array}{l}\text { TNM 3. } \\
\text { Edition( } \\
\text { 1978) }\end{array}$ & $\begin{array}{c}\text { Jewett - } \\
\text { Whitmore } \\
\text { system }\end{array}$ & Description in TNM nomenclature \\
\hline T0 & - & No evidence of tumour \\
\hline T1a & A1 & Three or fewer microscopic foci of carcinoma \\
\hline T1b & $\mathrm{A} 2$ & More than three microscopic foci of carcinoma \\
\hline T2a & B1 & $\begin{array}{l}\text { Tumour } 1.5 \mathrm{~cm} \text { or less in greatest dimension with normal tissue on a } \\
\text { least three slides }\end{array}$ \\
\hline $\mathrm{T} 2 \mathrm{~b}$ & B1 & $\begin{array}{l}\text { Tumour more than } 1.5 \mathrm{~cm} \text { in greatest dimension or in more than one } \\
\text { lobe }\end{array}$ \\
\hline T3 & $\mathrm{C} 1$ & $\begin{array}{l}\text { Tumour invades the prostatic apex, or into or beyond the prostatic } \\
\text { capsule, bladder neck, or seminal vesicle but is not fixed }\end{array}$ \\
\hline $\mathrm{T} 4$ & $\mathrm{C} 2$ & $\begin{array}{l}\text { Tumour is fixed or invades adjacent structures other than those listed } \\
\text { in T3 }\end{array}$ \\
\hline N0 & - & No regional lymph node metastasis \\
\hline N1 & D1 & Metastasis in a single lymph node, $2 \mathrm{~cm}$ or less at greatest dimension \\
\hline $\mathrm{N} 2$ & D1 & $\begin{array}{l}\text { Metastasis in a single lymph node more than } 2 \mathrm{~cm} \text {, but not more than } \\
5 \mathrm{~cm} \text { at greatest dimension, or in multiple lymph nodes none more } \\
\text { than } 5 \mathrm{~cm} \text { at greatest dimension }\end{array}$ \\
\hline N3 & D1 & $\begin{array}{l}\text { Metastasis in a lymph node more than } 5 \mathrm{~cm} \text { at greatest dimension } \mathrm{MX} \\
\text { Presence of distant metastasis cannot be assessed }\end{array}$ \\
\hline M0 & & No distant metastasis \\
\hline M1 & $\mathrm{D} 2$ & Distant metastasis \\
\hline
\end{tabular}

Table 5. Comparison of the 1978 TNM classification with the Whitmore-Jewett system

In situ prostate carcinoma (pTis) was omitted, and subgroups were introduced. Extension became the main parameter, replacing uni- or multifocality. This approach has been retained to the present day and in the fourth edition the pT3 separated into three 
subgroups according to the laterality of extracapsular spread. Apex infiltration was designated pT2 rather than pT3; however, the bladder neck was placed into the pT4a category. Also, nodal stages were classified in terms of size. With the incorporation of distant metastases, this classification applied is the same even now.

The fifth edition of TNM practically meant that the pT1 group was no longer used there, but was still used in clinical TNM. Although this stage could only be confirmed by histological testing, microscopic examination in itself was not suitable for the determination of the stage (anatomical extension). The basic objection was that, due to the sampling technique applied, the exclusion of a possible higher stage was impossible. In other words, a TUR sample is not suitable for excluding the possibility of extraprostatic spread or seminal vesicle involvement. Although extraprostatic extension may be observed in needle biopsies, the involvement of the seminal vesicle cannot be wholly excluded. Indeed, the T1c was justified only when tumour spread had also been confirmed by a clinical examination, even when it had been revealed in biopsies taken from both sides. This practice placed special emphasis on excluding the uncertainty introduced by the sampling technique. The identification of the pathological stage requires samples from radical prostatectomy and from the lymph nodal regions.

The fifth edition made an attempt to simplify matters. The involvement of only one or both lobes was to be taken into account by the classification into one of two subgroups. As will be seen below, this attempt eventually proved unsuccessful.

A detailed description of pathological stages helps to rule out anomalies such as the requirement of fixation to neighbouring structures in the case of the pT4 category. Only the criterion of bladder or rectum involvement was retained (inasmuch as it can be histologically assessed, i.e. it is contained in the sample). The spread to the bladder neck still received no special emphasis, so it was included as part of the pT4 category. Moreover, positivity of the surgical margin is mentioned for the first time, although this is due to surgical interventions than the physical extent of the tumour.

In case of tumours localised to the organ, the categories of the fourth classification applied ten years earlier were reintroduced in the sixth edition. The simplification that wished to take into account only the involvement of one or two lobes provided not to be sufficiently prognostic [52]. However, the classification used over nearly a quarter of a century and also adopted by the seventh edition is not satisfactory either. It is evident that in the case of two small tumour foci, their location on one or two lobes (pT2a vs. pT2c) 
has no significant impact on prognosis. But a large tumour involving half of a lobe probably has a worse prognosis than two small tumours of bilateral localisation, each measuring a few millimetres [53]. For this reason the need for classification in terms of size had already been recognised previously; however, the satisfactory way for such a classification has not yet been identified [54].

The seventh edition treated bladder neck infiltration separately, and classified it as pT3a.

\section{III/6 Testicular tumours}

Clinical and pathological stages are separated in the TNM system in general, but in the case of the testes this is not so explicit. The $\mathrm{T}$ categories are identical with two exceptions (pTis and pT4). This means that determination of the clinical stage necessitates histological examination following orchiectomy. In situ carcinoma can of course be examined only by applying histological methods; this category first appeared in the third edition of TNM.

In the fourth edition the significance of the involvement of rete testis as an anatomical region of testes diminished, and it was changed from pT2 to pT1. Epididymis involvement was moved from pT3 to pT2, funicular involvement from pT4a to pT3, and scrotal involvement to pT4. Thus subcategories were eliminated from the TNM system of the testicular cancer. As for lymph nodes, classification in terms of size was introduced like in other urological tumours and using identical size ranges.

In the fifth edition, vascular involvement was introduced as a staging factor and its presence meant pT2. Distant metastases were divided into two subgroups, namely lymph nodes beyond the given region and lung metastases (M1a) and metastases located beyond these structures (M1b). Even though it is not a pathological definable stage, the S stage, a new concept introduced as an exception to the TNM system based on anatomical extension, should also be mentioned. The new category served to confirm the prognostic significance of serum marker levels. In a minor modification of $\mathrm{pN} 2$, tumour spread beyond the lymph node irrespective of extension was also introduced.

In the sixth and seventh editions, no changes were made concerning the testis, which means that the same system has been used for 15 years, thus constituting the most stable stage classification among urological tumours. 


\section{III/7 Penile tumours}

The penile staging classification system introduced in 1966 by Jackson was in use up to the first TNM classification (Table 6). Classification in terms of categories was based on tumour operability and lymph node status, and did not take size, depth of infiltration or histological appearance into account [55].

\begin{tabular}{|l|l|l|}
\hline Jackson stage & TNM Stage Groups & \\
\hline Stage I & T1-T2, N0, M0 & Tumour limited to glans penis and/or prepuce \\
\hline Stage II & T1-T2, N0, M0 & Tumour extending onto shaft of penis \\
\hline Stage III & T1-T3, N1-2, M0 & $\begin{array}{l}\text { Tumour with malignant but operable inguinal } \\
\text { nodes }\end{array}$ \\
\hline Stage IV & T1-T4, N0-N4, M0-M1 & $\begin{array}{l}\text { Tumour invades adjacent structure; inoperable } \\
\text { nodes or distant metastasis }\end{array}$ \\
\hline
\end{tabular}

Table 6. Comparison of Jackson's categories with the firstly introduced TNM stages

As a single exception among urological tumours, penile cancer was already included in the first edition, and it was retained in the second and third editions without any change [56]. Pathological stage referred to clinical stage without modification. A penile tumour was treated as a superficial process by this system, and it was classified in terms of extension. Surgeons from Heidelberg worked out a modified TNM system, taking into consideration the localisation of the primary tumour and the extent of infiltration. The modifications did not result in any significant differences in the survival rate [57].

The fourth edition brought about considerable change. Verrucous carcinoma was introduced as the pTa stage, but pTis was also retained. Size as a determinant factor was replaced by the layers affected in the course of in-depth spread. The number and localisation of lymph nodes were taken into account instead of the infiltration of the surrounding structures, and this was not altered up to the sixth edition.

In the seventh edition, pT1 was divided into two subgroups, taking lymphovascular invasion as well as tumour differentiation into account. The meaning of T3 was restricted to urethral involvement. The prostate was treated as an "other neighboring stucture". The clinical and pathological statuses of lymph nodes were unambiguously separated, and in N3 the spread of metastases beyond the lymph node also gained importance, just like in the case of testicular tumours. 


\section{Changes in the histological classification}

WHO issues the publications known as "Blue Books" for the histological classification of tumours in various organs of the body, among them urological tumours. The first of these called "Histological Typing of Urinary Bladder Tumours" was published in 1973, followed by "Histological Typing of Testis Tumours" in 1977, "Histological Typing of Prostate Tumours" in 1980 and "Histological Typing of Kidney Tumours" in 1981. They contained short descriptions of the tumours, supplemented with large numbers of photomicrographs. Second editions on renal and testicular tumours were republished in 1998, on bladder tumours in 1999 and on prostate tumours in 2002. These already included immunohistochemical (IHC) photomicrographs. The two most recent WHO classifications are called "Pathology and Genetics. Tumours of the Urinary System and Male Genital Organs" (2004) and "Tumours of the Urinary System and Male Genital Organs" (2016) summarises urological tumours in one volume. The title itself implies that tumours are basically diseases of genetic origin. This publication defines tumour types, describes their epidemiology, key clinical features, macroscopic characteristics, histological and IHC properties, genetic deviations and prognostic and predictive factors. Categories are differentiated by applying classical pathological and genetic tests. These last two, even physically most extensive books, also contains a description of tumours of the penis.

\section{VI/1 Kidney tumours}

The first description of a kidney tumour was given by Miriel in 1810. Twelve additional cases were documented in the fifteen years following. The first classification was proposed in 1826 by König, who classified tumours according to their macroscopic appearance (fungoid, medullary, cicatrising and adipose). The first series of kidney tumours was compiled by Rayer in 1831-1838, and published in his three-volume “Treatise on Renal Disease" in 1841. He classified tumours into three groups based on their appearance and clinical features, namely (1) non-visible cancer (tumour of medullary appearance without kidney enlargement or haematuria); (2) caliceal cancer (with nephric pain and haematuria); and (3) cicatrising cancer (often associated with haematuria). In the next two decades, kidney tumour research focused on the histological approach in order to determine the histological origin of the cancer. When Robin described in 1855 that proliferating cells of the tubular epithelium form tumour nodules, he assumed that the cancer originated from the renal tubules. This observation was 
confirmed by Waldeyer in 1867 by autopsy findings [58]. In contrast, in 1883 Grawitz in his book entitled "Die entstheungen von Nierentumouren aus Nebennierengewebe" described renal cell carcinoma as a hypernephroma, which he thought originated from the adrenal gland due to its histological appearance [59]. In spite of the opinions of leading pathologists of the 20th century, this theory and the name "Grawitz tumour" or "hypernephroma" have survived and occasionally appear even in present-day publications [60].

WHO classification of 1981: International Histological Classification of Kidney

\section{Tumours}

This is the first international consensus classification that takes into consideration the microscopic appearance of the tumour, tumour cells and the histological pattern. Tumours were divided into benign and malignant tumours, but the main criterion of maligancy was a tumour diameter in excess of $3 \mathrm{~cm}$. Malignant tumours were designated adenocarcinoma or renal cell carcinoma. It was already known at that time that certain morphological types are associated with a more favourable prognosis. In the absence of adequate clinicopathological correlation, however, these were not accepted as independent entities. Hence, the only categories were adenoma, renal cell carcinoma and "others".

\section{The Mainz Classification (1986)}

For many years, renal cell carcinoma was considered to be a single pathological entity, and was subdivided into clear, granular and mixed cell variants. The granular cell variant with a predominantly papillary appearance was classified as papillary renal carcinoma. In 1976, Klein and Valensi described oncocytoma with a granular cell type appearance, an entity with excellent prognosis [61]. Its multiplex form was also described later [62] (Figure 4).

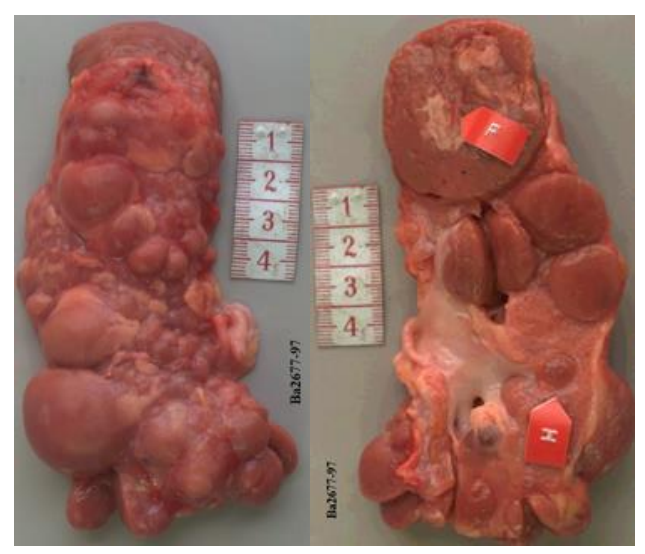

Figure 4. Kidney oncocytomatosis. The right kidney is occupied by a mass of oncocytomas causing renal insufficiency. The images were taken following removal of the renal capsule (left hand side) and its cut surface visible (right hand side) F: central mixoid area of the characteristically mahogany tumour; $\mathrm{H}$ : a small separate tumour 
In the same year, papillary tumours became a separate entity on the basis of their avascular angiographic appearance, and their histological identification was also refined [63]. Nine years later Thoenes et al. described chromophobe renal cell carcinoma, a cancer with clear cell features, closely resembling renal tumours experimentally induced in rats [64] (Figure 5).

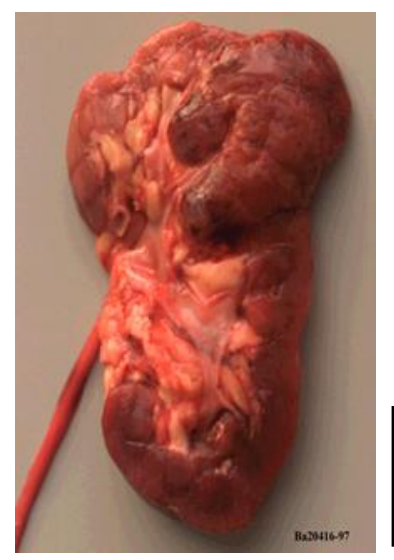

Figure 5. Chromophobe carcinoma. Its macroscopic appearance closely resembles that of oncocytoma

Somewhat later, collecting duct carcinoma with granular cell features was also recognised [65]. Significant overlaps, the clear and granular features and the marked clinical, pathological and phenotypic differences made the formulation of a new classification system necessary. The new system that became known as the Mainz Classification was proposed by Thoenes et al., and it has been widely adopted. Renal carcinoma of tubular epithelial origin was classified on the basis of traditional histological criteria, and the entities described earlier were all included [66] (Table 7).

\begin{tabular}{|l|}
\hline Tumour types \\
\hline Clear cell \\
\hline Chromophil (eosinophil, basophil) \\
\hline Chromophobe (typical, eosinophil) \\
\hline Collecting Duct Carcinoma \\
\hline Oncocytoma \\
\hline
\end{tabular}

Table 7. The Mainz Classification of renal tumours

\section{The Heidelberg/Rochester classification (1997)}

Concerns tumours are diseases of genetic origin. Because of this, it appears sensible that their classification should be based on the genetic deviations responsible for their emergence and progression. Loss of the short arm of chromosome 3 was identified as the characteristic feature of clear cell renal carcinoma [67], and the entities of the Mainz Classification have also been successfully paired with differential genetic characteristics [68]. These data were systematised by the Heidelberg/Rochester 
Classification [69, 70], the main aim of which was classification according to the histomorphological patterns characteristic of the entities separated on the basis of genetic differences. In other words, it can be applied in the course of routine histological examination, without a genetic test. The Heidelberg Classification (HC) has not been widely used [71]; however, it was adopted by the Rochester Classification as reflecting the consensus of the International Society of Urological Pathology (ISUP), except for differences in nomenclature and with supplementation of phenotypic descriptions (Table $8)$.

\begin{tabular}{|l|l|}
\hline Benign parenchymal neoplasms & The characteristic genetic alteration is not yet known. \\
\hline Metanephric adenoma & $\begin{array}{l}\text { Trisomy of chromosomes 7 and 17 and loss of the Y } \\
\text { Chromosome. }\end{array}$ \\
\hline Renal oncocytoma & $\begin{array}{l}\text { Del 1p, 14q and loss of the Y chromosome or } \\
\text { translocation between chromosome arm 11q13 and other } \\
\text { chromosomes in a subset of tumours7,8. Many } \\
\text { oncocytomas have an apparently normal karyotype. }\end{array}$ \\
\hline Malignant parenchymal neoplasms \\
\hline $\begin{array}{l}\text { Common or conventional } \\
\text { renal cell carcinoma }\end{array}$ & $\begin{array}{l}\text { Del 3p, (VHL mutation), Duplication of chromosome } \\
\text { band 5q22, deletion of chromosome arms 6q, 8p, 9p, } \\
\text { and 14q. }\end{array}$ \\
\hline Papillary renal cell carcinoma & $\begin{array}{l}\text { Trisomy of chromosomes 3q, 7, 8, 12, 16, 17, and } \\
\text { 20 and loss of the Y chromosome }\end{array}$ \\
\hline $\begin{array}{l}\text { Chromophobe renal cell } \\
\text { carcinoma }\end{array}$ & $\begin{array}{l}\text { LOH at chromosomes 1, 2, 6, 10, 13, 17, and 21 } \\
\text { and hypodiploid DNA content. }\end{array}$ \\
\hline Collecting duct carcinoma & The characteristic genetic alteration is not yet known. \\
\hline
\end{tabular}

Table 8. The Heidelberg/Rochester Classification

\section{WHO classification, 1998: Histological Typing of Kidney Tumours}

It was mentioned in the Introduction that classification gave reflections of the actual status of our knowledge, and should be modified in parallel with the accumulation of experience. The classification continued to be based on histological criteria, i.e. on morphologically identifiable cell types and histological patterns. Attention was called to the importance of the degree of tumour differentiation, which was ranked by a three-grade scale. It was pointed out that vascular spread and tumour extension also have to be taken into account. Three benign entities were discerned, namely papillary/tubulopapillary, oncocytic and metanephric adenomas. Clear cell appearance of every possible size was invariably treated as malignant. Also, the granular cell type as well as spindle cell cancer constituted separate categories. Additional separate entities were papillary, chromophobe 
and collecting duct cancers. This classification was, to a large extent, built upon the Mainz Classification and the chromophil type was discontinued.

WHO classification, 2004: Pathology and Genetics. Tumours of the Urinary System and Male Genital Organs

The clear cell type appearance was retained as a characteristic of malignancy. The separate category of granular cell type tumours, however, was abolished, because it was apparent that these do not differ from other entities either genetically or clinically, since clear cell type, papillary and chromophobe cancers as well as oncocytomas can also have an acidophilic appearance with granular cytoplasm [72]. The sacromatous (spindle cell) type also ceased as a separate category because it was realised that it was a poorly differentiated version of several tumour types. Papillary tumours, however, were divided into two groups, namely Type 1 small-cell and Type 2 eosinophilic papillary tumours [73]. Besides these, new entities such as familial renal cancer, translocation carcinoma, neuroblastoma-associated renal cell carcinoma, multicystic renal cell carcinoma, tubular, mucinous and spindle-cell renal carcinoma and mixed epithelial and stromal tumour were created. Also, the potentially aggressive epitheloid angiomyolipoma was described. Categories with mixed epithelial-mesenchymal morphologies as well as types resembling the primal nephric blastema also appeared among the groups added in 2004. Among benign entities, the subcategorisation of metanephrogenic tumours was completed, partly based on their discernibility on a genetic basis [74] (Table 9).

\begin{tabular}{|l|}
\hline Malignant renal cell tumours \\
\hline Clear cell renal cell carcinoma \\
\hline Multilocular clear cell renal cell carcinoma \\
\hline Papillary renal cell carcinoma \\
\hline Chromophobe renal cell carcinoma \\
\hline Carcinoma of the collecting ducts of Bellini \\
\hline Renal medulary carcinoma \\
\hline Xp11 translocation carcinomas \\
\hline Carcinoma associated with neuroblastoma \\
\hline Mucinous tubular and spindle cell carcinoma \\
\hline Renal cell carcinoma unclassified \\
\hline Benign renal cell tumours \\
\hline Papillary adenoma \\
\hline Oncocytoma \\
\hline Metanephric tumours \\
\hline Metanephric adenoma \\
\hline Metanephric adenofibroma \\
\hline Metanephric stromal tumours \\
\hline
\end{tabular}

Table 9. The renal tumour classification system used today 


\section{The Vancouver Classification (2013)}

This recent renal tumour classification system was created on the basis of the ISUP consensus, achieved after a review of the available abundance of published data. It listed fifteen morphologically separate entities with individual genetic characteristics, exceeding the WHO classification of 2004 by five subtypes. In a novel approach, newly recognised (separated) entities expected to be included in the next classification were also listed.

The Vancouver Classification applied several new approaches and made numerous proposals for changes to the WHO Classification of 2004. Multicystic renal cell carcinoma of the clear cell group was classified as a neoplasia with low malignant potential. The separation of the two types of papillary renal tumours was mentioned, but the oncocytic variant was not classed as a separate entity. Hybrid oncocytic chromophobe tumour, a disease of indolent course may occur in three different ways, namely in the Bird-Hogg-Dubé syndrome, in renal oncocytosis and in the form of sporadic neoplasia. At present it is identified as chromophobe renal cell cancer; however, it would be more correct to classify it as an oncocytic tumour of uncertain malignity [75].

WHO classification, 2016: Tumours of the Urinary System and Male Genital Organs

The fourth edition of the WHO 'blue book' published in 2016, contains significant modifications regarding renal tumours. Besides the introduction of five new entities based on the above-mentioned Vancouver Classification, important changes occurred in the definition of papillary adenoma and the terminology of the multilocular cystic renal neoplasm. The diameter of the former dramatically increased from $0.5 \mathrm{~cm}$ to the $1.5 \mathrm{~cm}$. The growing data revealed that this larger tumour has no capacity to metastasise. The latter is supplemented with the term "of low malignant potential" as several publications report no recurrence or metastasis in patients with multilocular cystic renal neoplasm.

The papillary RCC has traditionally been subdivided into type 1 and type 2 papillary RCC. It has been assumed that a subset of tumours have mixed histology. Recent molecular studies suggest that type 2 papillary RCCs may constitute not a single well-defined entity, but rather individual subgroups with different molecular backgrounds. 
The 2016 WHO classification refers to names of subtypes that have been assigned on the basis of predominant cytoplasmic features (e.g., clear cell and chromophobe renal cell carcinomas, architectural features, anatomic location of tumours, and correlation with a specific renal disease background as well as molecular alterations pathognomonic for RCC subtypes or familial predisposition syndromes. In contrast to the 2004 WHO classification, familial forms of RCC, which also occur in sporadic form (e.g., clear RCC in patients with von Hippel-Lindau syndrome) are now mentioned with the corresponding sporadic tumour types in joint chapters [76].

The histological classification of renal tumours has undergone significant change in the past thirty years. New morphological, immunohistochemical, cytogenetic and genetic knowledge has led to an expansion of the number of entities (Fig. 6). Tumours of the organs lying within the domain of urology should also be divided into benign and malignant groups. The border between these two groups, however, are not always distinct - a well-known example being the uncertainty surrounding the classification of papillary renal tumour, a relatively common cancer occurring as adenoma or carcinoma -, and histological diagnosis and determination of the histological subgroup is of decisive importance. Electron microscopic, immunohistochemical and molecular tests and examinations have circumscribed types with different responsiveness to therapy and diverse prognoses, and have gradually revealed the mechanisms of their emergence and development. The Heidelberg-Rochester consensus had a major influence on the last two WHO classifications.

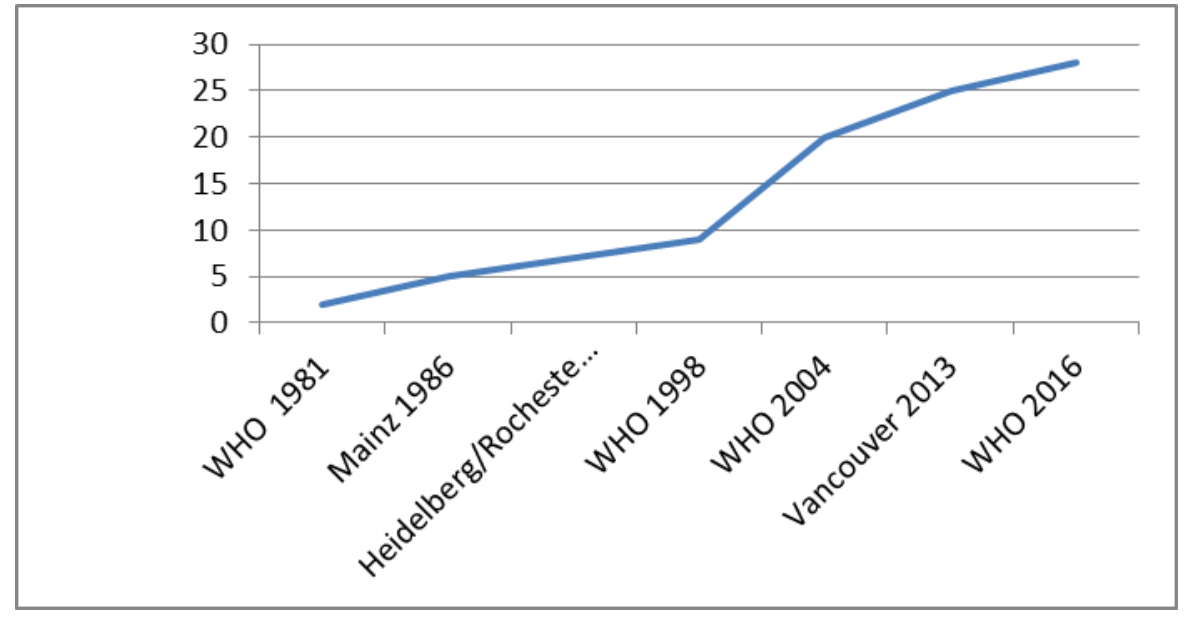

Figure 6. Increase in the number of renal tumour entities in successive classifications (Y axis: number of changes, $\mathrm{X}$ axis: name of classifications.) 


\section{IV/2 The possibility for genetic classification in the case of renal tumours}

The Heidelberg classification is essentially a histological classification, allowing the differentiation of various renal tumour types based on their microscopic phenotypes [69]. Genetic tests are required in the case of overlapping histological patterns. We sought to test the applicability of these genetic tests in three differential diagnostic problems occurring in the case of papillary renal tumours, using FISH (fluorescent in situ hybridisation):

a. Diagnostics of a rare composite tumour: papillary renal cell carcinoma embedded in an oncocytoma

b. Studies on genetic disorders considered characteristic of papillary cell carcinoma

c. Studies on the clonality of multiplex papillary kidney tumours.

The Heidelberg classification uses chromosomal deviations to characterise the individual types and it can therefore be conveniently tested by centromer- and locus-specific FISH probes.

A rare composite tumour: papillary renal cell carcinoma embedded in an oncocytoma

A 68-year-old male patient with a long history of hypertension was hospitalised with upper right abdominal pain. Abdominal ultrasonography and CT revealed a thickened gallbladder, cholelithiasis of the common bile duct, and a tumour with a diameter of $4 \mathrm{~cm}$ in the upper pole of the right kidney. After treatment of the biliary problem, right-side nephrectomy was carried out. A histological examination confirmed a papillary type 2 carcinoma embedded in an oncocytoma. No recurrence or metastasis formation was observed during the 8-month follow-up period.

Studies on genetic disorders considered characteristic of papillary cell carcinoma

Tumours originally interpreted as papillary based on their phenotypic appearance were randomly chosen from the renal cancer material of the Institute of Pathology, Medical University of Pécs, reclassified according to the Heidelberg criteria.

12155/92 L.J., female patient (68 yrs.): A tumour with a diameter of $5 \mathrm{~cm}$ located on the upper pole was removed by radical nephrectomy. No capsule involvement, pyelon or vein invasion or metastases were observed. 11644/96 N.D., female patient (70 yrs): No 
tumour metastasis was identifiable. A tan-coloured, necrotic, haemorrhagic tumour measuring $8 \times 7 \mathrm{~cm}$, infiltrating the renal capsule was removed. 2384/97 E. J., male patient (54 yrs.): His multiple left-side renal tumours were incidentally recognised by ultrasonography. A histological examination revealed two greyish-white tumours measuring 6 and $2.5 \mathrm{~cm}$ in diameter, respectively. An extensive vein invasion was observed in the larger tumour (Figure 7). 7723/98 R. I., female patient (45 yrs.): Her right-sided renal tumour was incidentally recognised by ultrasonography. During surgery, a right-side adrenal metastasis was observed and radical nephrectomy was performed.

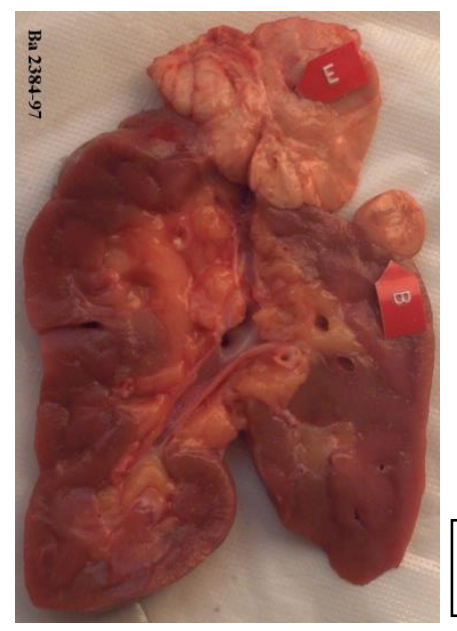

Figure 7. Double papillary renal tumour No. 2384/97

3138/98 M.A., female patient (42 yrs. A tumour with a diameter of $17 \mathrm{~mm}$ was removed in the course of partial resection. 8439/98 A. I., male patient (60 yrs.): His large left-side renal tumour was recognised when examined for haematuria. Lung metastases were confirmed. A neoplasm with a diameter of $11 \mathrm{~cm}$, intruding into the pyelon and the blood vessels was removed.

Examination of the clonality of multiple papillary kidney tumours

HA 473/99 Post-mortem description of the case of a male patient: He suffered from a chronic myeloproliferative disorder and died as a consequence of extensive thrombotic sequelae. An autopsy revealed two relatively large structures measuring 1.5 and $2.5 \mathrm{~cm}$ in the left kidney, and small, well-defined, yellowish-white, pinhead- and pepper-sized ones on both sides. The diagnosis was "Adenoma papillare multiplex renum" (multiply papillary adenoma of the kidneys).

\section{FISH and IHC examinations}

Frozen sections were made from native tissues and placed on sylanised slides. After drying at $56{ }^{\circ} \mathrm{C}$ overnight, the sections were stained with DAPI, followed by 
digestion by pepsin (Sigma Aldrich) for $18 \mathrm{~min}$ and optimisation of the digestion. For the isolation of nuclei, a frozen block of tissue with a diameter of $5 \mathrm{~mm}$ was subjected to mechanical separation, pre-digestion and cytocentrifugation. Hybridisation using alpha satellite probes specific for chromosomes 7, 17, Y and 8, 12, 16, 20 (Vysis Downers Grove, IL, USA and Cytocell Ltd., Cambridge, UK) and post-hybridisation washing were performed in accordance the manufacturer's recommendations. In addition to the $\mathrm{Y}$ chromosome, a probe specific for chromosome 7 or 17 was used as a positive internal control. The evaluation was carried out in a Zeiss Axioscope fluorescent microscope. A sample containing at least one hundred nuclei was examined and the percentage distribution was calculated. Values larger than 2.8 signals/nucleus were treated as trisomy and those larger than 3.8 as tetrasomy. The most common signal/nucleus ratio is given in percentages. Here, deviated cell numbers larger than $15 \%$ are treated as a significant deviation. In Table 12, the chromosome numbers are colour-coded.

IHC tests were performed on formalin-fixed, paraffin-embedded samples, making use of standard histopathological laboratory techniques. The antibodies applied, their manufacturers, clones and dilutions are shown in a publication [77].

The results of a FISH test on a frozen section are shown in Figure 8. On the left hand side, the nuclei of tubular epithelial cells show up in the cross-section of a normal renal tubule. In nuclei with normal karyotype, one green (Y chromosome) signal and two red (chromosome 7) signals can be seen. On the right hand side, a normal tubule is visible. On the other side the borderline between the tumour and the healthy tissue can be seen, where the normal tissue serves as an internal control. The green signal loss is visible in the tumour part and the red signal count is elevated.

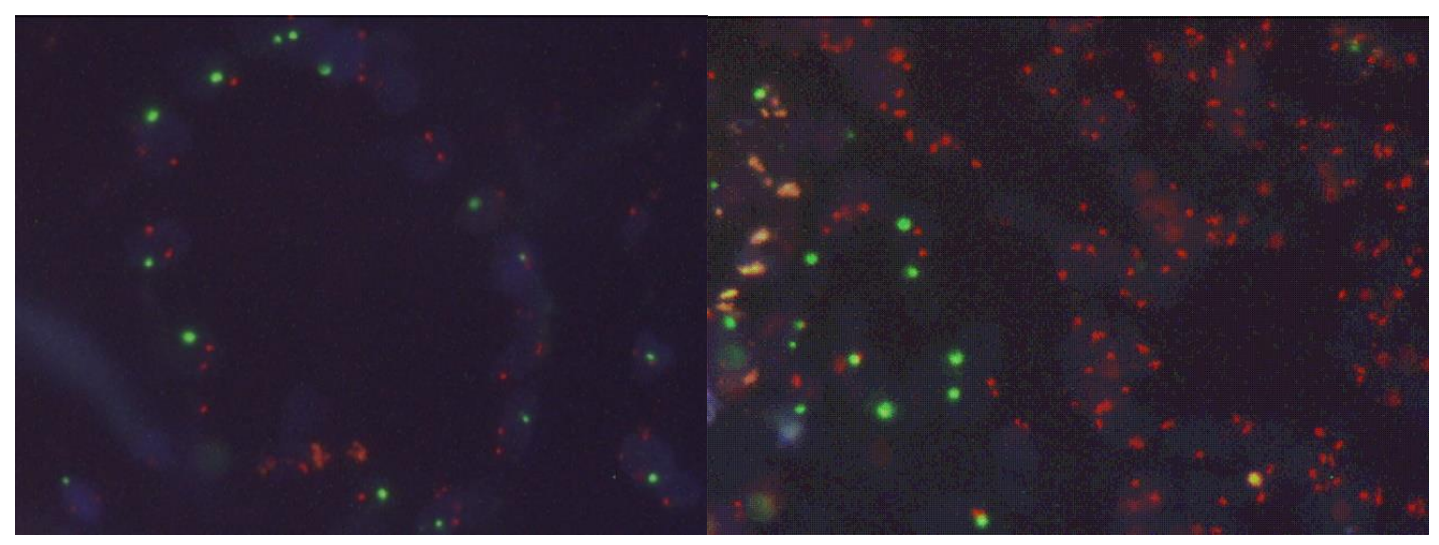

Figure 8 . The red signal marking chromosome 7 can be seen both in the renal parenchyma (a) and in the normal cells present in the papillary axes (b). The green signal marking the $\mathrm{Y}$ chromosome is present in tubular epithelial cells (a and $b$ left side), but is absent in papillary tumour cells ( $b$ right side). Owing to the well-preserved morphology, signal locations are clearly discernible 
In all but one of the histological slides of a rare composite tumour, a papillary renal tumour embedded in an oncocytoma, polygonal cells with ample eosinophilic, granular cytoplasm and uniform, round nuclei were observed forming nests and tubules. Along whit an oncocytoma, a papillary lesion measuring $1 \mathrm{~cm}$ in diameter, with papillary and tubulopapillary structure was microscopically identified in one section. This area was characterised by less voluminous eosinophilic, granular cytoplasm and focal nuclear pseudostratification. Moreover, lighter cytoplasm was focally present. Macrophages with foamy cytoplasm and a small number of psammoma bodies occurred in the papillary axes. The nuclei were generally of low grade, but areas with increased nucleus/cytoplasm ratios and visible nucleoli were also present, resulting in Fhurman grade 2. The oncocytoma was diffusely E-cadherin positive and weakly CD 117-positive, but negative for vimentin and alpha-methylacyl-CoA racemase (AMACR). The papillary areas were CK7, AMACR and vimentin positive and E-cadherin and CD 117 negative. Also, there was no deviation in the numbers of chromosomes 7,17 ,

\section{Studies on genetic abnormalities considered characteristic of papillary carcinoma}

The FISH results of randomly selected tumours reclassified according to the Heidelberg Classification (HC) and assessed as papillary on the basis of their phenotypic appearance, along with their key pathological characteristics are listed in Table 10. In five out of eight cases, at least one of the deviations in chromosome numbers was observed. Only in two cases (8439/98 and 6138/99) do pathological characteristics correspond to genetic criteria, confirming malignancy. In one case (12155/92), tetrasomy of only one chromosome occurring in adenoma was confirmed. In the case of a clearly malignant tumour (2384/97), only the deviation characteristic of adenoma could be observed. 


\begin{tabular}{|l|c|l|c|c|c|c|c|c|}
\hline Case & Diameter & Pathological characteristics & \multicolumn{6}{|c|}{ Percentage of cells } \\
\hline & $(\mathrm{mm})$ & & $\mathbf{Y}$ & $\mathbf{7}$ & $\mathbf{1 7}$ & $\mathbf{1 2}$ & $\mathbf{1 6}$ & $\mathbf{2 0}$ \\
\hline $3138 / 98$ & 17 & Prognosis depends of behaviour & - & $\mathbf{8 1 . 2}$ & $\mathbf{7 5 . 4}$ & $\mathbf{3 9 . 9}$ & ND & ND \\
\hline $8439 / 98$ & 110 & Pyelon and vessel invasion & $\mathbf{9 5 . 8}$ & $\mathbf{4 7 . 8}$ & $\mathbf{6 3 . 5}$ & $\mathbf{5 5 . 0}$ & $\mathbf{4 4 . 7}$ & $\mathbf{4 4 . 5}$ \\
\hline $12155 / 92$ & 50 & $\begin{array}{l}\text { Parenchyma or capsule } \\
\text { invasion }\end{array}$ & - & $\mathbf{4 6 . 4}$ & $\mathbf{8 9 . 5}$ & ND & ND & ND \\
\hline $11644 / 96$ & 80 & Necrosis, capsule invasion & - & $\mathbf{9 0 . 8}$ & ND & $\mathbf{7 0 . 1 5}$ & $\mathbf{8 8 . 3}$ & ND \\
\hline $2932 / 97$ & 40 & Vessel invasion, tumour emboli & ND & $\mathbf{8 7 . 5}$ & $\mathbf{9 0 . 9}$ & $\mathbf{8 7 . 8}$ & ND & ND \\
\hline $7723 / 98$ & 20 & Invasion, adrenal metastasis & - & $\mathbf{8 1 . 2}$ & $\mathbf{7 5 . 4}$ & ND & $\mathbf{8 6 . 5}$ & ND \\
\hline $2384 / 97$ & 60 & Vessel invasion & $\mathbf{9 5}$ & $\mathbf{5 0 . 6}$ & $\mathbf{5 9 . 3}$ & $\mathbf{9 2 . 5}$ & ND & ND \\
\hline $6138 / 99$ & 30 & Renal cell cancer & $\mathbf{9 5 . 1}$ & $\mathbf{5 5 . 8}$ & $\mathbf{5 4 . 2}$ & $\mathbf{6 5 . 1}$ & $\mathbf{5 0 . 2}$ & ND \\
\hline
\end{tabular}

Table 10. FISH results of tumours classified as papillary based on their phenotypic appearances. The colour coding is the following: grey, loss of the Y chromosome; blue, monosomy; green, disomy; red: trisomy; brown, tetrasomy. (ND: no data).

\section{Examination of the clonality of multiple papillary kidney tumours}

Six of the multiple papillary tumours incidentally found in both kidneys in the course of an autopsy were examined for chromosome number deviations characteristic of papillary tumours. The data values were also contrasted with tumour sizes (Table 11). No Y chromosome loss was found in the tumours originating from male kidneys; however, at least one deviation in chromosome number, consistent with papillary tumours according to $\mathrm{HC}$ was confirmed in each of these tumours. The most coherent deviation was the loss of chromosome 20, exhibited by a high number of cells in all tumours. The number of chromosomal deviations was proportional to the tumour size. Four chromosomes were affected in each of the two largest foci.

\begin{tabular}{|c|c|c|c|c|c|cc|}
\hline & Diameter & \multicolumn{6}{|c|}{ Percentage of cells } \\
\hline & $(\mathbf{m m})$ & $\mathbf{Y}$ & $\mathbf{7}$ & $\mathbf{1 7}$ & $\mathbf{1 2}$ & $\mathbf{1 6}$ & $\mathbf{2 0}$ \\
\hline 1. & $\mathbf{5}$ & $\mathbf{9 5 . 3}$ & $\mathbf{4 8 . 4}$ & $\mathbf{6 9 . 1}$ & $\mathbf{9 1 . 7}$ & $\mathbf{9 7 . 5}$ & $\mathbf{8 3 . 3}$ \\
\hline 2. & $\mathbf{1 5}$ & $\mathbf{9 3 . 7}$ & $\mathbf{8 4 . 0}$ & $\mathbf{8 8 . 6}$ & 39.6 & $\mathbf{9 3 . 4}$ & $\mathbf{8 9 . 9}$ \\
\hline 3. & $\mathbf{5}$ & $\mathbf{9 8 . 1}$ & 47,2 & $\mathbf{6 3 . 9}$ & $\mathbf{7 5 . 0}$ & $\mathbf{8 5 . 4}$ & $\mathbf{8 8 . 3}$ \\
\hline 4. & $\mathbf{1 5}$ & $\mathbf{9 3 . 2}$ & 49.3 & 55.8 & 77.0 & $\mathbf{9 4 . 1}$ & $\mathbf{7 3 . 1}$ \\
\hline 5. & $\mathbf{4}$ & $\mathbf{9 6 . 4}$ & $\mathbf{5 0 . 6}$ & $\mathbf{6 3 . 5}$ & $\mathbf{9 0 . 6}$ & $\mathbf{9 6 . 8}$ & $\mathbf{7 5 . 4}$ \\
\hline 6. & $\mathbf{2 5}$ & ND & $\mathbf{4 6 . 4}$ & 47.3 & $\mathbf{3 6 . 5}$ & $\mathbf{5 2 . 1}$ & $\mathbf{7 9 . 5}$ \\
\hline
\end{tabular}

Table 11. Results of FISH tests on multiple papillary renal tumours of a simple patient. According to $\mathrm{HC}$, deviations in the numbers of chromosomes Y, 7 and 17 are indicative of papillary adenoma, and additional changes in those of chromosomes 12, 16 and 20 are suggestive of papillary carcinoma. The colour coding is the following: grey, precence of the $\mathrm{Y}$ chromosome; blue, monosomy; green, disomy; red: trisomy; brown, tetrasomy. (ND: no data). 
Today, carcinomas are regarded as genetic diseases. Hence, it seems sensible that their classification be based on the genetic deviations responsible for their formation and development. Efforts in this direction have been made for nearly all tumour types. In the case of renal tumours, this approach was realised in HC [69]. Based on the chromosomal deviations considered characteristic of the individual renal tumour types used as marker deviations, three benign and five malignant entities were differentiated (Table 8). The papillary growth pattern may be present not only in papillary, but also other types of kidney carcinoma. In these cases of overlapping phenotypical picture the genetic tests could help differentiate among them.

Based on post mortem data, the most common renal tumours are papillary tumour [78]. In the absence of obvious signs of malignanacy such as invasiveness and metastasis formation, the differentiation of benign papillary adenomas and carcinomas is based on their size. Clinicopathological and genetic data, however, reveal that biological behaviour is determined by genetic deviations rather than size [79]. Factors considered characteristic of papillary adenoma are the multiplication of chromosomes 7 and 17 and loss of the $\mathrm{Y}$ chromosome. Papillary carcinoma is characterised by numerical deviations of additional chromosomal regions and the duplication of the 1q region is a sign of fatal progression [80].

In situ hybridisation and its non-radioactive variants, namely the sensitive FISH and the chromogenic in situ hybridisation (CIS) that can be detected by traditional microscopy may be applied to test papillary renal tumours even in fine-needle biopsies [81, 82]. The first FISH test on a renal tumour in Hungary was carried out by the Author; using frozen sections of a papillary renal adenoma from an autopsy (see Figure 5). In addition to demonstrating the wider applicability of this technique, the objective of the test was to confirm the loss of the $\mathrm{Y}$ chromosome, viewed as a characteristic feature of papillary renal tumour. The results were first reported at the Conference of Pathology in Gyula, Hungary in 1998 [83]. It was later described by László Pajor, Professor of Pathology, who introduced the pathological application of in situ hybridisation in Hungary [84].

We tested the diagnostic applicability of the genetic characteristics of papillary renal tumours in three different circumstances: 
In the diagnostics of a rare composite tumour: papillary renal tumour embedded in an oncocytoma

A tumour with a diameter of $4 \mathrm{~cm}$ was incidentally observed on the upper pole of the right kidney of a 68-year-old male patient. A histological examination after nephrectomy revealed a papillary type 2 carcinoma embedded in an oncocytoma. Although an oncocytoma and a renal cell carcinoma are separate entities, they may occur simultaneously in the same or in the contralateral kidney. Chromophobe renal tumours and oncocytomas can be closely related and they exhibit similar phenotypes of distal tubular origin, hence their joint occurrence is not surprising. Oncocytomas and papillary renal cell carcinomas, however, originate from different cell types. The occurrence of papillary renal cell cancer in an oncocytoma is extremely rare. Their joint occurrence has been reported by only two publications. The first of these was a 7-mm type 1 papillary carcinoma of a 75-year-old male patient embedded in an oncocytoma with a diameter of $15 \mathrm{~mm}$. The papillary tumour was readily identifiable in haematoxylin-eosin stained sections, based on its appearance clearly separated and differing from the surrounding oncocytoma. In contrast to the case studied in our laboratory, the papillary tumour cells showed trisomy of chromosome 7. The second case was that of a 73-year-old female patient, who had a $1.5-\mathrm{mm}$ papillary tumour within an oncocytoma with a diameter of 36 $\mathrm{mm}$. Although no chromosome examination was performed, the typical morphology and the immunohistochemical results confirmed the diagnosis.

In our case the diagnosis of a combined tumour, a papillary renal tumour embedded in an oncocytoma was based on microscopic morphology and immunohistochemistry [77]. In certain regions the two tumour types were sharply divergent; in other foci they exhibited morphologies that were difficult to differentiate. To proceed further, we decided to apply immunohistochemical techniques. In view of the size and the structure of the lesion and the immunohistochemical pattern, the diagnosis was type 2 papillary carcinoma within the oncocytoma. No deviations were observed in FISH tests using centromer-specific probes for chromosomes 7, 17 and Y.

\section{Testing for genetic deviations considered characteristic of papillary carcinoma}

Reclassification, by using microscopy, of the renal tumour material of the Institute of Pathology, Medical University of Pécs according to HC was completed earlier [85]. According to $\mathrm{HC}$, tumours judged papillary based on their phenotypic appearance can only be further classified as "adenoma" or "carcinoma" by genetic tests. Deviations in the 
number of chromosomes Y, 7 and 17 are indicative of papillary adenoma, whereas additional numerical deviations of chromosomes 12, 16 and 20, are indicative of papillary carcinoma (Table 8). FISH tests on eight tumours diagnosed as malign on the basis of clinicopathological evidence produced mixed results (Table 11). Only in two of the eight cases were the $\mathrm{HC}$ criteria met, i.e. deviations supporting malignancy observed. In one case the genetic test only confirmed adenoma, even though malignancy was corroborated not only by the size but also by vessel invasion. In each of two other cases, only one chromosome was affected, which is insufficient for classification. In three cases, no deviations were detected. Our results are in good accordance with the data published by Klatte et.al. from UCLA in California [86]. According to the University of California at Los Angeles Kidney Cancer Program Database, 1825 patients were treated with renal cancer between 1985 and 2007; 158 papillary renal carcinomas were identified according to the histological criteria of papillary tumours [87]. In 65 consecutive cases cytogenetic tests were performed. Deviations were found in 57 cases (88\%). Trisomy of chromosome 7 was observed in 35 cases (54\%), that of chromosome 17 in 31 cases (48\%), that of chromosome 12 in 28 cases $(43 \%)$ and that of chromosome 16 in 22 cases (34\%). These results are quite similar to those obtained on our non-representative material. We found deviations in the number of the relevant chromosomes in 6 out of 8 cases $(6 / 8,75 \%)$ : chromosome 7, 5/9 (62\%); chromosome 17, 3/8 (38\%); chromosome 12, 3/8 (38\%); chromosome 16, 1/8 (13\%). Brunelli et al. examined 10 adenomas and the same number of carcinomas using the FISH technique, but defined no threshold value; however, when they found trisomy in one cell, they considered the tumour was involved. They examined the normal parenchyma surrounding the tumour using the same methods. In all 20 cases (10 adenomas and 10 carcinomas), they tested the six relevant chromosomes $(7,12,16$, 17, 20 and Y). They did not find a case without at least one cell exhibiting a deviation of at least one chromosome! However, they did not find any deviation more frequent than $12 \%$. Using these criteria and with the given test sensitivity, the frequency of tri- or tetrasomy in the adenomas was $90 \%$ for chromosome $7,70 \%$ for chromosome $17,40 \%$ for chromosome $12,50 \%$ for chromosome 16 and $50 \%$ for chromosome 20. Nearly the same distribution of deviations was found in the carcinomas: the frequency of numeric anomalies was $100 \%$ for chromosome $7,70 \%$ for chromosome $17,50 \%$ for chromosome $12,60 \%$ for chromosome 16 and $40 \%$ for chromosome 20 [88]. If the frequency of deviations observed in normal renal tissue (i.e. 12\%) is chosen as the threshold value, the Californian and Hungarian data are quite similar. However, it is also evident from the 
work of Brunelli et al. as well as from our own findings that adenoma and carcinoma cannot be classified only on the basis of the genetic characteristics defined in the HC [88].

Studies on the clonality of multiplex papillary kidney tumours

Partial nephrectomy, a technique applied with increasing frequency entails the risk of recurrence due to the presence of residual tumour cells. $7-25 \%$ of renal cancers are multifocal, which is a consequence of either tumour seeding within the organ or the initial multifocal character of the tumour [89]. In the case of multifocal clear-cell renal cancers, monoclonality (i.e. tumour seeding within the organ) has been confirmed [90]. However, papillary renal cell cancer is the most common renal cell tumour. In the course of 14,763 post mortem examinations, Wunderlich et al. found 260 renal tumours, 36 of which (18.95\%) were multifocal [91]. Applying the findings of molecular genetic tests, papillary tumours are polyclonal, i.e. they emerge independently [90]. Our studies yielded the same result. Although the frequency of chromosomal deviations considered specific by the HC increased in proportion to tumour size, this was not coherent; polyclonality, however, was apparent.

\section{IV/3 Bladder tumours}

The international reference centre responsible for the histological classification of the tumours of the male urogenital tract was initiated by the WHO in 1965 . Five hundred histological sections and the associated clinical data were sent to the collaborating institutions for preliminary classification. The results were then summarised by eight pathologists in 1968. Each entity was supplemented with a description and photomicrographs. Needless to say, attention was called to the fact that the classification reflected contemporary knowledge. As a result, the nomenclature became more uniform. At that time, the designation "transitional cell" rather than "urothelial" was used; however, terms such as "epithelioma" were successfully eliminated. At that time the clear separation between benign and malignant tumours had not yet been achieved.

In the second edition, attention was called to the fact that, even though the designation "transitional cell" was widely used, the urothelium is an independent epithelium type, and it is more practica to designate its tumours as "urothelial". Owing to the wide contemporary use of the former, the two designations were treated as equivalent. Papillary neoplasia of low malignant potential was introduced, for tumours which had previously been classified as a highly differentiated carcinoma. It was not coherent to 
include atypia/dysplasia in in situ urothelial cancer and classify its variants as a malign subgroup, since the former is ambiguously non-malignant, the latter is only a premalignant state. However, the designation of transitional cell cancers as squamous or glandular "metaplasia" was eliminated, in accordance with the present-day terminology, according to which metaplasia means the transformation of one differentiated tissue free of malignancy into another one. Also new entities were created, namely adenocarcinoma, urachal, clear cell carcinoma and small cell carcinoma. A new epithelial abnormality was hyperplasia, which may be either flat or papillary in appearance. Besides this, new tumour-like lesions were labelled myofibroblastous tumour and postoperative spindle-cell nodule.

The third classification applied the designation "urothelial" exclusively and the notion of transitional epithelium was rejected. Several new subtypes were described. These were de novo squamous cell and glandular carcinomas, now constituting a separate group with several additional members like nested, microcystic, micropapillary, lymphoepithelioma-like, plasmocytoid, sacromatous and giant cell carcinomas. Small cell tumours were moved to the novel group of neuroendocrine carcinomas.

The fourth edition of WHO classification brought few changes. The urothelial proliferation of uncertain malignant potential was introduced among the noninvasive urothelial lesions. Urothelial carcinoma has long been known to have a remarkable propensity towards divergent differentiation, which is observed most commonly in association with high grade and locally advanced carcinomas. The incidence in cystectomy specimens can reach $33 \%$ and this is generally associated with aggressive behaviour. Therefore the previously used term "infiltrating urothelial carcinoma" is supplemented with the definition "divergent differentiation" and it is recommended that pathologists report the percentage of divergent histologies. The new entity represents the tumours that arise from a bladder diverticulum.

\section{IV/4 Prostate tumours}

In the first classification of the prostate tumours, published in 1981 it was not known whether a real benign epithelial tumour (adenoma) or stromal tumour (leimyoma or fibroma) actually exist or these circumscribed tissue excesses are rather simply hyperplasias. Thus only a single benign lesion, namely papillary adenoma was included, which was retained unaltered in the second edition, but was absent from the third one. At that time the various forms of adenocarcinoma, such as small and large acinar, cribriform 
and solid, were still used as designations of histological subtypes; however, they are completely absent in the next classification because they were incorporated into the Gleason grade system. The categorisation of prostate cancer in the first two classifications as clinical, occult, incidental and latent carcinoma is quite interesting. The latter meant tumours detected in the course of an autopsy and, similar to the other categories, represented tradition rather than individual histological entities. It is due to this shortcoming, among others, that "Histological Typing of Prostate Tumours" was viewed as the least valuable volume of the WHO series by the recension of the Journal of Clinical Pathology [92]. Nevertheless, these categories were retained in the second edition. Significant advances in the latter were the appearance of preinvasive prostate intraepithelial (PIN) carcinoma and the recognition of the neuroendocrine type.

In the third edition, the three-grade classification of PIN, applied from the beginning, was simplified to a more reproducible two-grade system, but it emphasised the difficulty of making a reliable distinction between low grade PIN and normal and hyperplastic epithelium. A single benign epithelial tumour called basal cell adenoma was retained. Moreover, the morphologies of the various Gleason grades were elaborated upon. In 2005, a shift took place, making Gleason 6 rather than Gleason 7 the most frequent pattern. At the same time, this also led to an embedding of the Gleason classification [93].

The fourth edition of the WHO classification appeared in the 2016, which contained two important changes, along with the description of the latest results of prostate cancer genetics and its immunophenotype. One of them is a new modified Gleason grading diagram where every form of cribriform and poorly formed tumour glands are included as a Gleason pattern 4. It is recommended that pattern 4 percentages be reported if it is the highest grade within the Gleason score 7, because a low percentage of pattern 4 may be treated with active surveillance. The other is the introduction of the recently developed grade groups system called the ISUP grade, which more accurately reflects the prognosis and is better suited than the Gleason score in a clinical context.

\section{IV/5 Testicular tumours}

In order to achieve a uniform histological classification of testicular tumours, a classification by experimentalists was compiled in 1971, which was applied to 250 cases in 12 centres. The finalised system was published later in 1973. The notable similarities between testicular tumours and ovarian tumours were also taken into account. The 
significant differences in occurrence, age distribution and clinical behaviour, however, ruled out the possibility of applying an identical classification for both groups. Here, $60 \%$ of testicular tumours display a mixed histological character. In spite of this fact, even the first classification may be considered successful, as it has been subjected to relatively few substantial modifications. In the second edition, just like that for prostate tumours, the in situ stage of germ cell tumours is included as well. It is supplemented by some smaller entities and some, such as dermoid cysts, are treated as distinct. One of the most significant changes of the third edition was the inclusion of the malignant group for both the Leydig and Sertoli cell tumours.

The biggest differences between the 2016 WHO classification and the previous version concern the germ cell tumours. These tumours arise from the progression of intratubular malignant germ cells. Such cells were usually designated as either carcinoma in situ or intratubular germ cell neoplasia. The use of different terms for the identical lesion had been a source of some confusion, so germ cell neoplasia in situ (GCNIS) was proposed. The germ cell tumours are now broadly separated into two quite different groups, namely those derived from GCNIS and those unrelated to GCNIS based on genetic, prognostic and clinical differences [76].

\section{IV/6 Penile tumours}

The vast majority of malignant tumours of the penis are squamous cell carcinomas. Most previous classification schemes were exclusively morphology based. The 2016 WHO classification presents a new classification based on clinicopathologic uniqueness and its connection with human papillomavirus (HPV) infections [76].

\section{Results}

Besides the histologic type, the most important of a malignant tumour is the stage, since this is what will determine the post-operative treatment as well as prognosis. TNM-based staging will have been used for half a century and it has become widely accepted. One reason for its success is that it is easy to use and can be applied to all the different organs. Its general acceptance due to a broad-based consensus made possible the performance of clinical studies with increasing case numbers and a comparison of different treatment procedures. However, it has to be applied with circumspection, because the TNM system is under continuous change, not only when new editions appear about every five years, but also due to the in-between revisions. (There have been three of 
these, namely in 1973, 1982 and 1992). During the comparison of consecutive issues, special attention should be paid to the fact that although the notation system of pTNM, i.e. pT, pN, pM and their subcategory labels do not change (with a few exceptions, such as the appearance of the $\mathrm{V}$ and $\mathrm{S}$ categories), the underlying content does. In other words, if earlier categories need be translated to the updated nomenclature, it may be impossible to do so. For example, a pN classification based on size cannot be compared to another based on the number of lymph nodes or their localisation.

\section{VI/1 The directions of evolution of the stage classification}

When changes in the pTNM system of urological tumours are depicted in graphical form, it is apparent that the degree of changes is constant and continuous (Fig. 9).

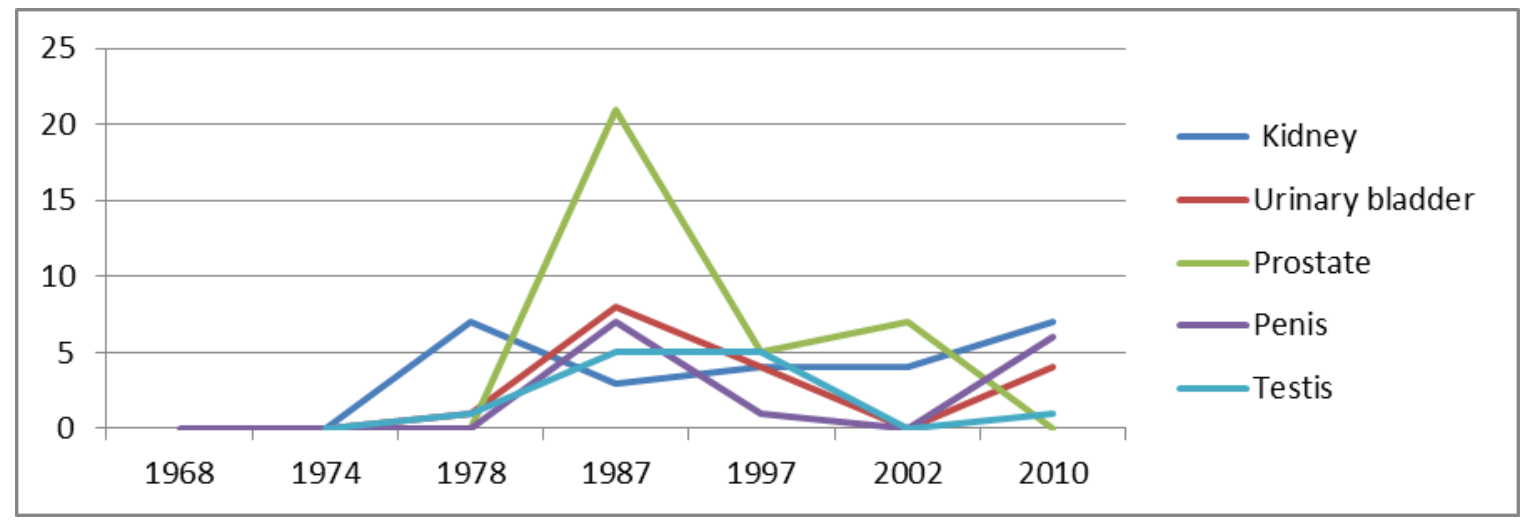

Figure 9. The pTNM system of urological tumours is continuously changing. (Y axis: number of changes, $\mathrm{X}$ axis: year of editions.)

This is not reassuring, because a trend in development is not visible here. Ideally, one would like the number of necessary modifications to decrease over time and the codification system to stabilise.

When, however, $\mathrm{pT}$ and $\mathrm{pN}$ components are analysed separately (pM was practically unaltered), changes in pT appear to point towards some slight stabilisation (Fig. 10). 


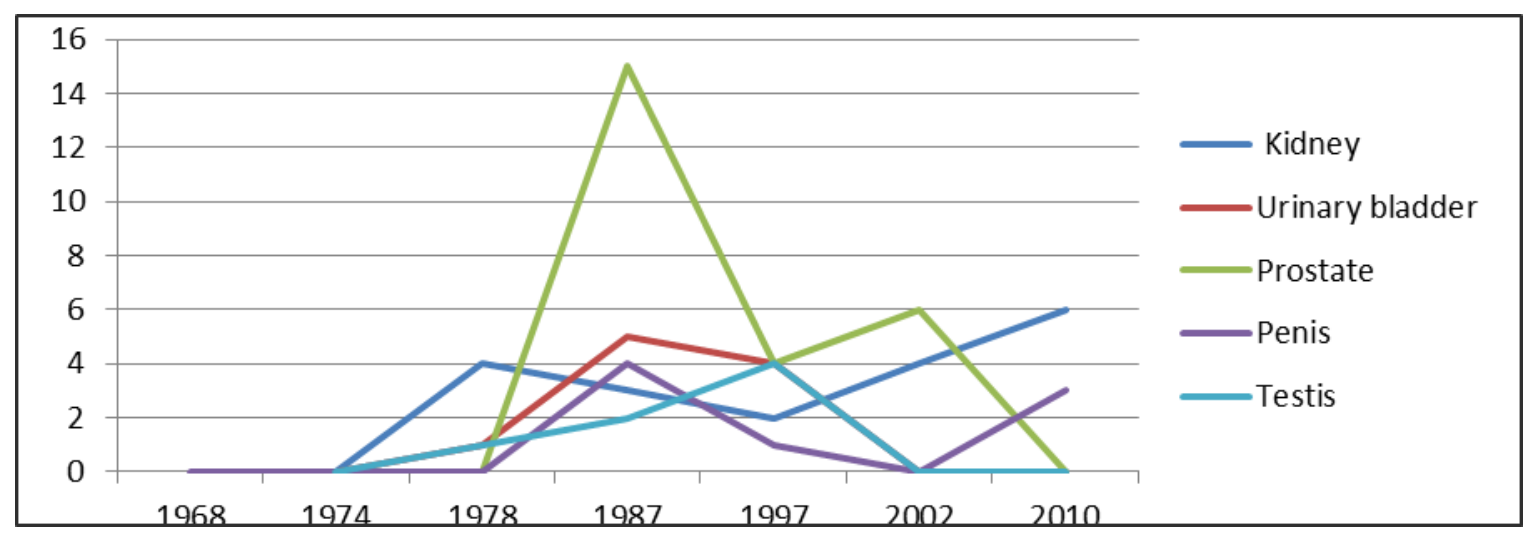

Figure 10. Changes in pT categories pointing towards stability. The exceptions are the kidney and the penis. ( $\mathrm{Y}$ axis: number of changes, $\mathrm{X}$ axis: year of editions.)

Changes in the classifications of testicular and bladder tumours have already shown a decreasing tendency in earlier editions, and the same can be observed for prostate tumours in the last edition. In contrast, the number of modifications in the classification of kidney tumours has increased in the last three editions and that of penile tumours in the last two editions. The stage classification of lymph nodes has displayed significant variations from the beginning, without any sign of stability, if we ignore the lymph node categories of testicular cancer in the last edition (Fig. 11).

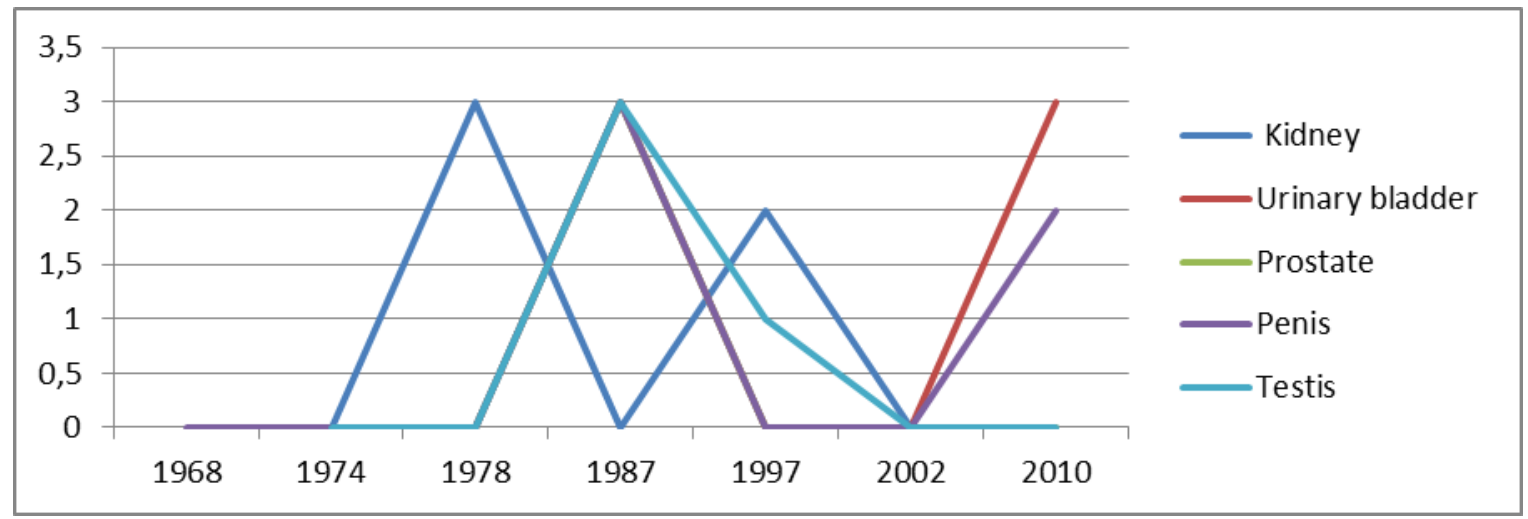

Figure 11. The stage classification of lymph nodes has had significant variations, without any indication of stability, if we disregard the lymph node categories of testicular cancer in the last edition. The prostate curve totally and the urinary bladder curve partially covered by other organs.) ( $\mathrm{Y}$ axis: number of changes, $\mathrm{X}$ axis: year of editions.)

The TNM system essentially describes the involvement of anatomical structures, or defines categories based on tumour size. Over the years, attempts have been made to incorporate as many prognostic factors as possible. This, however, endangers its ease of 
use and its ease of comparability over different organs, which helps explain the efforts made by some to preserve the TNM as a purely anatomical system. The most important engines of the development of it were: studies which presented growing numbers of cases with their prognostic data on one hand and the increasingly precise systematisation of knowledge with more accurate definitions, the wide dissemination of concepts and the incorporation of other systems on the other. However, among these factors there are no new clear methodologies and cut-up standards. It may not be an exaggeration to say that, had he been given the seventh TNM Classification Atlas, a pathologist active at the beginning of the last century, using the techniques available at that time, could have provided a stage classification that might be valid even today.

Our study has revealed that the successive TNM classifications might be regarded as stations of a slow process of development. This is corroborated by the decreasing number of modifications in the description of primary tumours. Up until now, an increasing number of stages have retained their meaning over more and more editions. It is also of interest to look at the organs and stages that still display a considerable variation. This knowledge is useful not only for the researcher, but also for the practising physician, because it is not sufficient to know the rules - their meaning and limits also need to be clearly recognised. However, studies based on increasing numbers of cases provide little assistance in promoting development and resolving the uncertainties of stage classification; and small statistical shifts themselves should not be considered conclusive.

In our opinion, up to now the examination methods and their standardisation have received insufficient attention. The pathological stage is mostly determined by microscopy. The areas to be examined have to be selected, but this is done visually, retaining a significant subjective component in the examination method. One way to reduce this subjective factor may be to embed the entire organ and apply a suitable, accurate procedure along geometrical lines. Urology is fortunate in this aspect, because all the organs treated readily lend themselves to this approach. The necessary procedure was implemented some time ago for the prostate. The anatomical structures of samples derived from the kidney, the testicle and the penis are somewhat more complicated than those of the prostate, but still do not attain the complexity of a cystoprostatectomy sample, representing seven organs (urethra, prostate, two seminal vesicles, bladder, and two ureters). We therefore applied a geometric approach to develop a cut-up protocol that 
was easy to use in everyday practice for the stage classification of radial cystectomy samples [33].

\section{V/2 The advantages of the GDPRC in radical cystectomies}

Radical cystectomy preparations can be complexes of seven organs in case of males. At present their involvement is still being examined in a non-standardised fashion, depending to a large extent on the subjective assessment of the pathologist performing the cut-up. We identified this circumstance as a fundamental cause of the scattering of published pathological stage frequencies. Taking into consideration the above statement of Donald G. Skinner, doyen of American urology, we devised a protocol that allows the embedding of the entire sample. Based on 138 cases, we found that the findings accurately reflected the statistical average of 15,586 cystectomies. The deviations were due to more detailed processing: the case numbers of the pTis-pT2 group turned out to be lower and those in the pT3-pT4 group to be higher. In the case of pT4, the difference was significant $(11.36 \%$ vs. $16.6 \% p=0.049)$ [33]. It was later found by a research group in Aachen that processing a whole organ is not necessary for a more accurate stage determination. They, however, used a self-created category, the so-called pTsum (= "sum" means the stage of cystectomy and the preceding TURB stage together) as a baseline, and did not perform an examination based on the canonical TNM system [94]. As is evident from our historical review of bladder tumour staging, the inclusion of the pT stage of preoperative TURB is by no means new. The Jewett-Strong-Marshall classification in 1952 took into account the TURB stadium obtained one month before cystectomy [6]. However, the fact that this has not been incorporated in the TNM system is quite apparent to us, as a cystectomy stage should demonstrate the situation in the respective sample. Nevertheless, we found that pTsum, to some extent, reflects the statistical data from a large number of cases, which are generated after embedding the entire sample [95]. Interestingly, Gaisa et al. asserted that the biological behaviour of the tumour is better reflected by pTsum than by the traditional pTNM system. Although they agreed with the greater accuracy of embedding the entire sample, they did not consider it more useful [96]. Even though the indication of pTsum appears worthy of consideration, its prognostic significance as one of the main objectives of the TNM system is basically called into question by the survival data reported by Gaisa et al.. Namely, after the first twenty months, a larger number of cases with pTsum category 1 died than cases with pTsum category 2 [97]. We think that the embedding of the entire sample is a progressive technique. Intravesically administered, molecular targeted anti-tumour therapies are 
expected to become available soon, and other, more conservative treatments and screens may also become more efficient. Consequently, we will certainly have to examine an increasing number of small, partially regressing tumours and we won't be able to rely solely on our human senses.

\section{V/3 Incorporation of new scientific results provides the basis for changes in histological classification}

The development of histological classification - unlike that of pathological staging has been definitely driven by new methodologies. The initial light microscopic images have been supplemented by immunohistochemical data and, most recently, the discrimination of new entities has been made possible by genetic information, as for instance in the case of renal Xp11 translocation carcinoma. Since carcinomas are rooted in genetic disorders, it is sensible to classify them on the basis of genetic factors responsible for their development. Since these initial genetic factors cannot be corrected in the course of tumour evolution, they appear more coherent than images of the microscopic phenotype in the course of clonal propagation. Among urological tumours, a progressive, genetically based classification has so far been published for only one urological tumour type, namely renal tumours (Heidelberg/Rochester classification). Our review of the development of histological classifications, however, has revealed that although genetic information about kidney cancer has greatly increased, to date there is no widespread acceptance of a purely genetic classification system.

\section{V/4 Histological and genetic classification in the case of papillary renal tumours}

Our studies were carried out about five years before the publication of the comprehensive reviews cited before [86-91]. Our intention was to utilise the HC in diagnostic practice, on the basis of the chromosomal disorders described in the publications that laid its foundations, because the chromosomal deviations described by the HC appeared highly coherent and diagnostic [98, 99]. We reported our results at the Congress of the Hungarian Society of Pathologists, held in Gyula Hungary in 1998 [80]. Since our results did not fall into the accepted "mainstream", we did not attempt to increase the case numbers or publish our results. The research team working in Heidelberg has since published data that conforms with the HC [80]. Nevertheless, neither the WHO classification immediately following the HC, nor the last Vancouver Classification has adopted the differentiation of renal tumours based only on genetic differences. Chromosomal deviations that may be linked to renal tumours are listed, 
together with immunohistochemical data, as characteristics to support the microscopic image of the phenotype. Our own studies have also confirmed much the same thing. In the case of the papillary renal tumour embedded in an oncocytoma, its histological type was successfully verified in spite of the fact that it did not exhibit the chromosomal deviations that are characteristic of it. We were able to do this, because similar conclusions had been drawn in our earlier studies on papillary renal carcinoma and multiple papillary tumours. After realising that carcinomas are basically genetic diseases, great interest was focused on the genetic classification of renal tumours, embodied by the HC. Our findings are in general agreement with the data presented in the literature; however, as our genetic knowledge is at present still limited, more accurate genetic information regarding tumour evolution will have to be collected.

\section{Summary of the results}

Stage and histological type are key histopathological parameters, but the consecutive stage and histological classifications display significant differences. They vary and are unstable from a practical point of view. However, do the ever-newer classifications represent steps towards an evolution? Or are they merely a rearrangement of our knowledge supplemented by new, mostly statistical data as part of an endless process? To date, we have not found a study that investigated the development of the TNM system and the histological classification of urological tumours. Therefore we reviewed the successive editions of the WHO and UICC classifications. Our study has revealed that these might be regarded as stations of a slow process of evolution towards to the stabilisation. We though that improvement of methodology of staging and histology assessments, using a more precise procedures and modern examinations processes can accelerate this development.

This was why we introduced a new cut-up protocol of urinary bladder cancer to decrease pathologist subjectivity and we examined the applicability of genetic classification in the differential diagnostics of papillary kidney tumours. Nowadays both procedures are an integral part of our daily routine. Knowing their limitations, they prove to be valuable supports in uropathological work. 


\section{Acknowledgements}

First and foremost I wish to express my gratitude to my supervisor Prof. László Pajor for his perspicacity, inspiration and constant help.

I am particularly grateful to Prof. Béla Iványi for having given the opportunity of bringing my skills to light and Prof. Gábor Cserni who critically analysed and supported my scientific work. Further thanks to David Curley for his kind help beyond proofreading.

I would like offer my heartfelt thanks for prior masters; Prof. Tivadar Mikó who has created world level environment for my histological work, Prof. Gyula Kovács who provide the basis of my scientific view and Prof. László Tiszlavicz who always every helped me improve my professional skills. I am thankful to László Pajor, professor at Pathology Institute in Pécs and Maria Kneif for their kind support my early activity in the world of molecular pathology. I will never forget the help of Dr. Endre Kálmán and Dr. Tamás Tórnoczky in at beginning my profession.

I will always retain the memory of my first tutor Dr. Tamás Magyarlaki who with Dr. István Buzogány showed me the attraction of uropathology. I express my special thanks to Dr. László Kaizer FRCPath and to Dr. István Németh for their help, whose friendship has always been important in my life.

I would also like to extend my grateful thanks to my colleagues Adrienn Hajdu, Dr. Gabriella Pankotai-Bodó and and Anita Beraczkáné Nagy for their support in my daily work.

Last but not least, I thank support my family, without whom I would have never gone this far.

This work was supported by GINOP-2.3.2-15-2016-00020 MolMedEx TUMORDNS project. 


\section{References}

1. Greene, F.L. and L.H. Sobin, The staging of cancer: a retrospective and prospective appraisal. CA Cancer J Clin, 2008. 58(3): p. 180-90.

2. Flocks, R.H. and M.C. Kadesky, Malignant neoplasms of the kidney; an analysis of 353 patients followed five years or more. J Urol, 1958. 79(2): p. 196-201.

3. Jewett, H.J. and G.H. Strong, Infiltrating carcinoma of the bladder; relation of depth of penetration of the bladder wall to incidence of local extension and metastases. J Urol, 1946. 55: p. 366-72.

4. Jewett, H.J., Carcinoma of the bladder: influence of depth of infiltration on the 5-year results following complete extirpation of the primary growth. J Urol, 1952. 67(5): p. 67280.

5. Jewett, H.J., Comments on the staging of invasive bladder cancer two B's or not two B's: that is the question (apologies to Shakespeare, Hamlet. Act III, sc. I, 1. 56). J Urol, 1978. 119(1): p. 39.

6. Marshall, V.F., The relation of the preoperative estimate to the pathologic demonstration of the extent of vesical neoplasms. J Urol, 1952. 68(4): p. 714-23.

7. van Dijk, P.R., et al., Downstaging of TURBT-Based Muscle-Invasive Bladder Cancer by Radical Cystectomy Predicts Better Survival. ISRN Urol, 2011. 2011: p. 458930.

8. Hautmann, R.E., et al., Radical cystectomy for urothelial carcinoma of the bladder without neoadjuvant or adjuvant therapy: long-term results in 1100 patients. Eur Urol, 2012. 61(5): p. 1039-47.

9. Herrmann, E., et al., The prognostic impact of pelvic lymph node metastasis and lymphovascular invasion on bladder cancer. Int J Urol, 2008. 15(7): p. 607-11.

10. Madersbacher, S., et al., Radical cystectomy for bladder cancer today--a homogeneous series without neoadjuvant therapy. J Clin Oncol, 2003. 21(4): p. 690-6.

11. Mallen Mateo, E., et al., [Stage pT0 bladder tumors after radical cystectomy: a review of our series]. Actas Urol Esp, 2006. 30(8): p. 763-71.

12. May, M., et al., Multicenter evaluation of the prognostic value of pT0 stage after radical cystectomy due to urothelial carcinoma of the bladder. BJU Int, 2011. 108(8 Pt 2): p. E278-83.

13. Roupret, M., et al., Oncologic outcomes and survival in pT0 tumors after radical cystectomy in patients without neoadjuvant chemotherapy: results from a large multicentre collaborative study. Ann Surg Oncol, 2011. 18(13): p. 3833-8.

14. Rink, M., et al., Stage-Specific Impact of Tumor Location on Oncologic Outcomes in Patients With Upper and Lower Tract Urothelial Carcinoma Following Radical Surgery. Eur Urol, 2012. 
15. Rodriguez Faba, O., et al., Clinical predictive factors of poor outcome in patients with stage pT0 disease at radical cystectomy. J Urol, 2011. 186(2): p. 442-7.

16. Stein, J.P., et al., Radical cystectomy in the treatment of invasive bladder cancer: longterm results in 1,054 patients. J Clin Oncol, 2001. 19(3): p. 666-75.

17. Takahashi, A., et al., Radical cystectomy for invasive bladder cancer: results of multiinstitutional pooled analysis. Jpn J Clin Oncol, 2004. 34(1): p. 14-9.

18. Tilki, D., et al., Characteristics and outcomes of patients with clinical carcinoma in situ only treated with radical cystectomy: an international study of 243 patients. J Urol, 2010. 183(5): p. 1757-63.

19. Tollefson, M.K., et al., Downstaging to non-invasive urothelial carcinoma is associated with improved outcome following radical cystectomy for patients with cT2 disease. World J Urol, 2012.

20. Vickers, A.J., et al., Clinical benefits of a multivariate prediction model for bladder cancer: a decision analytic approach. Cancer, 2009. 115(23): p. 5460-9.

21. Yu, R.J., et al., Superficial (pT2a) and deep (pT2b) muscle invasion in pathological staging of bladder cancer following radical cystectomy. J Urol, 2006. 176(2): p. 493-8; discussion 498-9.

22. Cheng, L., et al., Staging and reporting of urothelial carcinoma of the urinary bladder. Mod Pathol, 2009. 22 Suppl 2: p. S70-95.

23. Shariat, S.F., et al., Discrepancy between clinical and pathologic stage: impact on prognosis after radical cystectomy. Eur Urol, 2007. 51(1): p. 137-49; discussion 149-51.

24. Lopez-Beltran, A., et al., Handling and pathology reporting of specimens with carcinoma of the urinary bladder, ureter, and renal pelvis. A joint proposal of the European Society of Uropathology and the Uropathology Working Group. Virchows Arch, 2004. 445(2): p. 103-10.

25. Parkin, D.M., The global burden of urinary bladder cancer. Scand J Urol Nephrol Suppl, 2008(218): p. 12-20.

26. Herr, H.W., Staging invasive bladder tumors. J Surg Oncol, 1992. 51(4): p. 217-20.

27. Paik, M.L., et al., Limitations of computerized tomography in staging invasive bladder cancer before radical cystectomy. J Urol, 2000. 163(6): p. 1693-6.

28. Herr, H.W., Routine CT scan in cystectomy patients: does it change management? Urology, 1996. 47(3): p. 324-5.

29. Baltaci, S., et al., Computerized tomography for detecting perivesical infiltration and lymph node metastasis in invasive bladder carcinoma. Urol Int, 2008. 81(4): p. 399-402.

30. Swinnen, G., et al., FDG-PET/CT for the preoperative lymph node staging of invasive bladder cancer. Eur Urol, 2010. 57(4): p. 641-7. 
31. Svatek, R.S., et al., Discrepancy between clinical and pathological stage: external validation of the impact on prognosis in an international radical cystectomy cohort. BJU Int, 2011. 107(6): p. 898-904.

32. Teloh HA. Methods in Surgical Pathology Springfield, IL, 1957, Thomas Chapter 26 8082

33. Sukosd, F., B. Ivanyi, and L. Pajor, Accurate determination of the pathological stage with gross dissection protocol for radical cystectomy. Pathol Oncol Res, 2014. 20(3): p. 67785 .

34. Rosai And Ackerman's Surgical Pathology 10th ed. Edited by Juan Rosai. St. Louis, MO: Mosby, 2011 p. 2913-14

35. Soto, E.A., G.H. Friedell, and A.J. Tiltman, Bladder cancer as seen in giant histologic sections. Cancer, 1977. 39(2): p. 447-55.

36. Hind, A., et al., Histopathological study of 110 cystectomy specimens for bladder cancer by an original mapping method. J Exp Clin Cancer Res, 1998. 17(1): p. 59-64.

37. Rosai And Ackerman's Surgical Pathology 10th ed. Edited by Juan Rosai. St. Louis, MO: Mosby, 2011 p. 2913-14

38. Yiou, R., et al., Outcome of radical cystectomy for bladder cancer according to the disease type at presentation. BJU Int, 2002. 89(4): p. 374-8.

39. Hotston, M., et al., What is the significance of pT0 at cystectomy? Surg Oncol, 2006. 15(2): p. 65-9.

40. Palapattu, G.S., et al., Cancer specific outcomes in patients with pT0 disease following radical cystectomy. J Urol, 2006. 175(5): p. 1645-9; discussion 1649.

41. Jewett, H.J., The historical development of the staging of bladder tumors: personal reminiscences. Urol Surv, 1977. 27(2): p. 37-40.

42. Cheng, L., et al., Tumor size predicts the survival of patients with pathologic stage T2 bladder carcinoma: a critical evaluation of the depth of muscle invasion. Cancer, 1999. 85(12): p. 2638-47.

43. Boudreaux, K.J., Jr., et al., Comparison of american joint committee on cancer pathological stage T2a versus T2b urothelial carcinoma: analysis of patient outcomes in organ confined bladder cancer. J Urol, 2009. 181(2): p. 540-5; discussion 546.

44. Tilki, D., et al., Validation of the AJCC TNM substaging of pT2 bladder cancer: deep muscle invasion is associated with significantly worse outcome. Eur Urol, 2010. 58(1): p. $112-7$.

45. Scosyrev, E., J. Yao, and E. Messing, Microscopic invasion of perivesical fat by urothelial carcinoma: implications for prognosis and pathology practice. Urology, 2010. 76(4): p. 908-13; discussion 914.

46. Dalbagni, G., et al., Cystectomy for bladder cancer: a contemporary series. J Urol, 2001. 165(4): p. 1111-6. 
47. Donat, S.M., et al., Mechanisms of prostatic stromal invasion in patients with bladder cancer: clinical significance. J Urol, 2001. 165(4): p. 1117-20.

48. Shen, S.S., et al., Prostatic involvement by transitional cell carcinoma in patients with bladder cancer and its prognostic significance. Hum Pathol, 2006. 37(6): p. 726-34.

49. Montironi, R., et al., Critical evaluation of the prostate from cystoprostatectomies for bladder cancer: insights from a complete sampling with the whole mount technique. Eur Urol, 2009. 55(6): p. 1305-9.

50. Malmström PU.:Why has the survival of patients with bladder cancer not improved?BJU Int. 2008 Feb;101(3):267-9. Epub 2007 Nov 13.

51. Whitmore, W.F., Jr., Hormone therapy in prostatic cancer. Am J Med, 1956. 21(5): p. 697-713.

52. May, F., R. Hartung, and J. Breul, The ability of the American Joint Committee on Cancer Staging system to predict progression-free survival after radical prostatectomy. BJU Int, 2001. 88(7): p. 702-7.

53. van der Kwast, T.H., et al., International Society of Urological Pathology (ISUP) Consensus Conference on Handling and Staging of Radical Prostatectomy Specimens. Working group 2: T2 substaging and prostate cancer volume. Mod Pathol, 2011. 24(1): p. $16-25$.

54. van der Kwast, T.H., Substaging pathologically organ confined (pT2) prostate cancer: an exercise in futility? Eur Urol, 2006. 49(2): p. 209-11.

55. Jackson, S.M., The treatment of carcinoma of the penis. Br J Surg, 1966. 53(1): p. 33-5.

56. International Union Against Cancer. Committee on TNM Classification., TNM classification of malignant tumours. 1968, Geneva,. 79 p.

57. Lichtenauer, P., H. Scheer, and T. Louton, On the classification of penis carcinoma and its 10-year survival. Recent Results Cancer Res, 1977(60): p. 110-9.

58. Delahunt, B. and J.N. Eble, History of the development of the classification of renal cell neoplasia. Clin Lab Med, 2005. 25(2): p. 231-46, v.

59. Grawitz PA 1883 Arch Klin Chir 30:824-830

60. Shuch, B., et al., Quality of pathological reporting for renal cell cancer: implications for systemic therapy, prognostication and surveillance. BJU Int, 2011. 108(3): p. 343-8.

61. Klein, M.J. and Q.J. Valensi, Proximal tubular adenomas of kidney with so-called oncocytic features. A clinicopathologic study of 13 cases of a rarely reported neoplasm. Cancer, 1976. 38(2): p. 906-14.

62. Warfel, K.A. and J.N. Eble, Renal Oncocytomatosis. Journal of Urology, 1982. 127(6): p. 1179-1180.

63. Mancilla-Jimenez, R., R.J. Stanley, and R.A. Blath, Papillary renal cell carcinoma: a clinical, radiologic, and pathologic study of 34 cases. Cancer, 1976. 38(6): p. 2469-80. 
64. Thoenes, W., S. Storkel, and H.J. Rumpelt, Human chromophobe cell renal carcinoma. Virchows Arch B Cell Pathol Incl Mol Pathol, 1985. 48(3): p. 207-17.

65. Fleming, S. and H.J. Lewi, Collecting duct carcinoma of the kidney. Histopathology, 1986. 10(11): p. 1131-41.

66. Thoenes, W., S. Storkel, and H.J. Rumpelt, Histopathology and classification of renal cell tumors (adenomas, oncocytomas and carcinomas). The basic cytological and histopathological elements and their use for diagnostics. Pathol Res Pract, 1986. 181(2): p. $125-43$.

67. Zbar, B., et al., Loss of alleles of loci on the short arm of chromosome 3 in renal cell carcinoma. Nature, 1987. 327(6124): p. 721-4.

68. van den Berg, E., et al., Cytogenetic analysis of epithelial renal-cell tumors: relationship with a new histopathological classification. Int J Cancer, 1993. 55(2): p. 223-7.

69. Kovacs, G., et al., The Heidelberg classification of renal cell tumours. J Pathol, 1997. 183(2): p. 131-3.

70. Storkel, S., et al., Classification of renal cell carcinoma: Workgroup No. 1. Union Internationale Contre le Cancer (UICC) and the American Joint Committee on Cancer (AJCC). Cancer, 1997. 80(5): p. 987-9.

71. Hollingsworth, J.M., et al., Variable penetrance of a consensus classification scheme for renal cell carcinoma. Urology, 2007. 69(3): p. 452-6.

72. Lopez-Beltran, A., et al., 2004 WHO classification of the renal tumors of the adults. Eur Urol, 2006. 49(5): p. 798-805.

73. Delahunt, B., et al., Morphologic typing of papillary renal cell carcinoma: comparison of growth kinetics and patient survival in 66 cases. Hum Pathol, 2001. 32(6): p. 590-5.

74. Pesti, T., et al., Mapping a tumor suppressor gene to chromosome 2p13 in metanephric adenoma by microsatellite allelotyping. Hum Pathol, 2001. 32(1): p. 101-4.

75. Srigley, J.R., et al., The International Society of Urological Pathology (ISUP) Vancouver Classification of Renal Neoplasia. Am J Surg Pathol, 2013. 37(10): p. 1469-89.

76. Moch, H., et al., The 2016 WHO Classification of Tumours of the Urinary System and Male Genital Organs-Part A: Renal, Penile, and Testicular Tumours. Eur Urol, 2016. 70(1): p. 93-105.

77. Sejben, I., et al., Papillary renal cell carcinoma embedded in an oncocytoma: Case report of a rare combined tumour of the kidney. Can Urol Assoc J, 2013. 7(7-8): p. E513-6.

78. Bostwick, D.G. and J.N. Eble, Urologic surgical pathology. 1997, St. Louis: Mosby-Year Book. x, 788 p.

79. Kovacs, G., Molecular cytogenetics of renal cell tumors. Adv Cancer Res, 1993. 62: p. 89-124. 
80. Szponar, A., et al., Three genetic developmental stages of papillary renal cell tumors: duplication of chromosome 1q marks fatal progression. Int J Cancer, 2009. 124(9): p. 2071-6.

81. Haudebourg, J., et al., Strength of molecular cytogenetic analyses for adjusting the diagnosis of renal cell carcinomas with both clear cells and papillary features: a study of three cases. Virchows Arch, 2010. 457(3): p. 397-404.

82. Kos, Z., et al., Fluorescence in situ hybridization as an adjunct tool in the diagnosis of primary and metastatic renal cell carcinoma in fine needle aspiration specimens. Diagn Cytopathol, 2014. 42(12): p. 1013-23.

83. Sükösd Farkas,Kneif Mária, Buzogány István és Pajor László: Papilláris vesetumor in situ hibridizációs vizsgálata Patológus Kongresszus, Gyula, 1998. augusztus 26-29.

84. Pajor, L., [Interphase cytogenetics in oncologic diagnosis]. Orv Hetil, 1998. 139(49): p. 2939-46.

85. Buzogány I.,Magyarlaki T., Villányi K., Sükösd F.: A Thoenes féle citomorfológiai „, Mainz klasszifikáció” alkalmazása vesesejtesrákok hisztológiai osztályozásakor Magyar Urológia, 1997. IX./4. 324-331

86. Klatte, T., et al., Cytogenetic and molecular tumor profiling for type 1 and type 2 papillary renal cell carcinoma. Clin Cancer Res, 2009. 15(4): p. 1162-9.

87. Kovacs, G., Papillary renal cell carcinoma. A morphologic and cytogenetic study of 11 cases. Am J Pathol, 1989. 134(1): p. 27-34.

88. Brunelli, M., et al., Gains of chromosomes 7, 17, 12, 16, and 20 and loss of Y occur early in the evolution of papillary renal cell neoplasia: a fluorescent in situ hybridization study. Mod Pathol, 2003. 16(10): p. 1053-9.

89. Jones, T.D., et al., Molecular genetic evidence for the independent origin of multifocal papillary tumors in patients with papillary renal cell carcinomas. Clin Cancer Res, 2005. 11(20): p. 7226-33.

90. Junker, K., et al., Clonal origin of multifocal renal cell carcinoma as determined by microsatellite analysis. J Urol, 2002. 168(6): p. 2632-6.

91. Wunderlich, H., et al., Multifocality in renal cell carcinoma: A bilateral event? Urol Int, 1999. 63(3): p. 160-3.

92. HM Cameron: Histological Typing of Prostate Tumours J Clin Pathol 1981;34:815 doi:10.1136/jcp.34.7.815

93. Epstein, J.I., et al., The 2005 International Society of Urological Pathology (ISUP) Consensus Conference on Gleason Grading of Prostatic Carcinoma. Am J Surg Pathol, 2005. 29(9): p. 1228-42.

94. Gaisa, N.T., et al., In cystectomy specimens with bladder cancer whole organ embedding increases the detection rate of histopathological parameters, but not of those with prognostic significance. Virchows Arch, 2015. 466(4): p. 423-32. 
95. Farkas Sükösd, Béla Iványi, László Pajor:What can be more prognostic than the pTNM category assessed on radical cystectomy specimens? (Letter to editor) Virchows Arch. 2015 Oct;467(4):481-2.

96. Gaisa NT1, Knüchel-Clarke R.: Response letter to "What can be more prognostic than the pTNM category assessed in radical cystectomy samples?" by Sükösd F, Ivanyi B and Pajor L.Virchows Arch. 2015 Oct;467(4):483-4.

97. Farkas Sükösd, Béla Iványi, László Pajor:What can be more prognostic than the pTNM category assessed on radical cystectomy specimens? (Letter to editor)Virchows Arch. 2015 Oct;467(4):481-2.

98. Kovacs, G., The value of molecular genetic analysis in the diagnosis and prognosis of renal cell tumours. World J Urol, 1994. 12(2): p. 64-8.

99. Kovacs, G., Molecular differential pathology of renal cell tumours. Histopathology, 1993. 22(1): p. 1-8. 


\section{Publications}


Publication I. 
Címkék: hisztopatológiahólyagdaganat

Rovatok: Klinikai tanulmányok

Szerző: Sükösd Farkas dr. ${ }^{1}$ Pajor László dr. ${ }^{2}$

${ }^{1}$ Szegedi Tudományegyetem ÁOK, Patológiai Intézet, Szeged

${ }^{2}$ Szegedi Tudományegyetem ÁOK, Urológiai Klinika, Szeged

\section{A radikális cystectomiás minta teljes szövettani feldolgozásának módszere és költségkihatása}

The methodology and the expenses of the macroblock evaluation of the cystectomy specimen

Lapszám: Magyar Urológia | 2012 | 24. évfolyam 2. szám

Összefoglalás: A szerzők 138 radikális cystectomiás preparátum teljes makroblokkos szövettani feldolgozását végezték el 2008 és 2012 között, természetesen a kivett regionális nyirokcsomókkal együtt. A közleményben a patológiai feldolgozás új módszerét ismertetik. Ez elméletileg kizárja, hogy szemben a korábbi célzott kimetszésekkel, bármilyen daganat, vagy daganatrész rejtve maradjon. A szerzők a módszer jelentőségét a pT0, illetve pT2B, és a pT3A stádiumok vizsgálatában, valamint a prosztatára terjedés esetében hangsúlyozzák.

SUMMARY: The authors performed macroblock evaluation of 138 cystectomy specimen between 2008 and 2012, together with the regional lymph nodes. New concept was presented the total pathological working up even in male and in female bladder. On the contrary of the previously applied systemic sections, the total oriented elaboration excludes undiscovered tumors or tumor parts. The authors emphasized the importance of the method especially in pT0, pT2B, pT3A and pT4 cases if the tumor invades the prostate.

A klinikai döntésekben - és a prognózis meghatározásában - legfontosabb adat a hólyagdaganat stádiuma. Sajnos ez még a korszerü képalkotó-vizsgálatokkal is csak igen nagy tévedéssel állapítható meg, így döntő a kórszövettani vizsgálat maradt (1). A TURból nyert szövettani preoperatív eredmény viszonylag még a legmegbízhatóbb, de a mintavétel hibájából adódóan ez is szignifikánsan eltér a cystectomiás preparátum stádiumától. Kérdés az, hogy az arany standardnak tekintett cystectomiás anyag patológiai feldolgozása vajon teljesen megbízható-e? Nem lehetséges-e, hogy a hólyagban lévő egyes daganat vagy daganatrészek nem kerülnek kimutatásra? A jelen nemzetközi és hazai gyakorlatban a hólyagból makroszkópos irányítással történnek a kimetszések, és csak ezek a részek kerülnek beágyazásra, illetve feldolgozásra. A kimetszésen kívüli területek rejtve maradnak, így a daganat kiterjedtségére vonatkozó adatok egy része elvész. Más szervek esetén is egyre gyakoribb a makroblokkos feldolgozás. Polgárjogot nyert már az emlődaganatok esetében, és mind kiterjedtebben alkalmazzák prosztatarák vonatkozásában is. A teljes feldolgozásnak a klinikai szempontokon túl tudományos értéke is van, ami által valóbb képet nyerhetünk a hólyagrák biológiai viselkedéséről. A teljes szövettani feldolgozás hazai elterjedését a szük anyagi lehetőségek korlátozhatják. 


\section{Anyag és módszer}

A Szegedi Tudományegyetem Urológiai Klinikáján 2008 és 2012 között operált 138 radikális cystectomiás preparátum makroblokkos feldolgozása történt meg. A minták 99 férfitől és 39 nőtől származtak. Az átlagéletkor 62,28 év volt. A férfiaké 64 év (legfiatalabb 41, legidősebb 76), míg a nőké 60,56 év (legfiatalabb 49, legidősebb 71). A mintákat $10 \%$-os formalinban fixáltuk, minimum három napig. A metszési síkokat sematikusan az 1. ábrán szemléltetjük, és ezt orientált kivágási protokollnak neveztük el (OKP). A férfi és női hólyag feldolgozása természetesen jelentősen különbözik (1. ábra).

1. ábra Javasolt kivágási protokoll sematikus ábrázolása, férfi (A) és női (B) cisztektómiákra. A melső falon vezetett orientációs bemetszést követően képzett metszési síkok: 1: urethra reszekciós vonal és apex, 2: prosztata hátrafelé szélesedő harántszeletek, 3: hólyagbázis 12 sugárirányú kimetszése, 4: húgyhólyag haránt szeletek, 5: kupola szagittális metszetei. (A sorszámozás aluról fölfelé a feldolgozás sorendjében történt.)
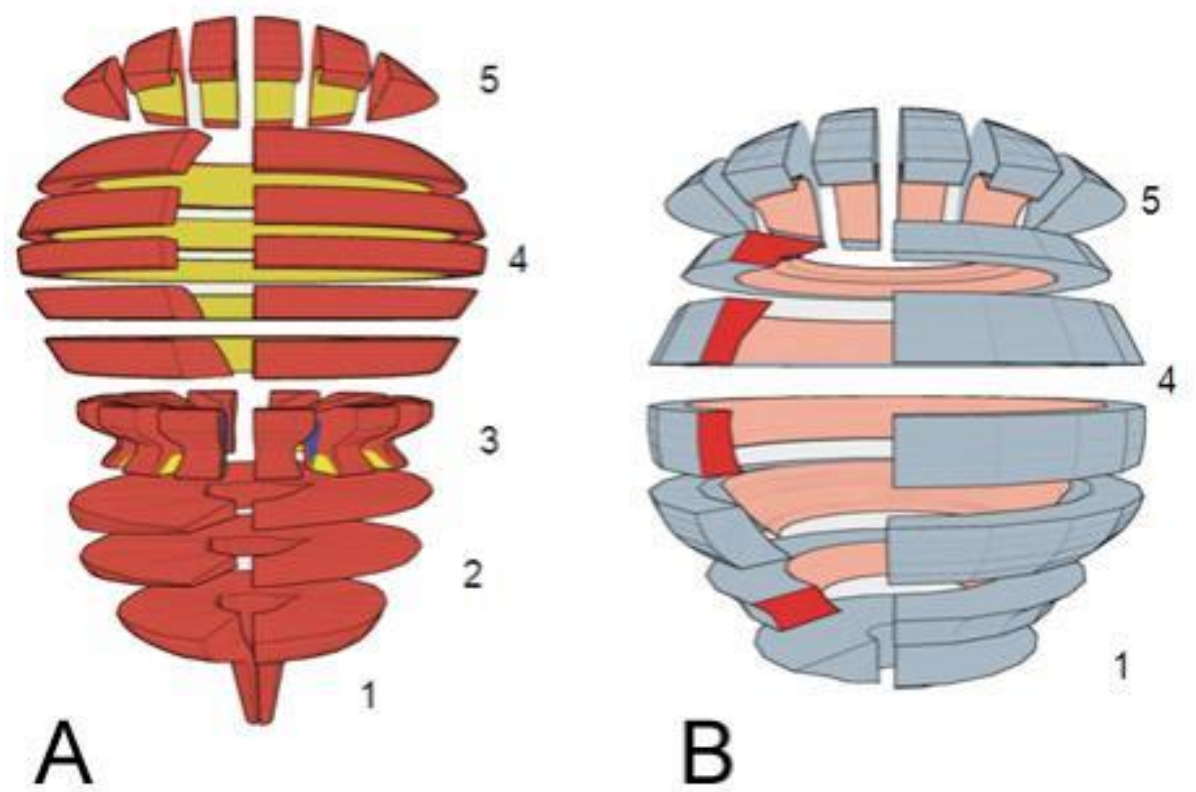

Férfihólyag esetén a kivágás lépései (1. A ábra)

- Urethralis reszekciós vonal,

- a prosztata ék alakú metszete,

- a hólyagalap sugárirányú metszetei a prosztata kraniális széllel,

- hólyagtest harántszeletek,

- hólyagkupola,

- a vesicula seminalis. 


\section{Női hólyag esetén a kivágás lépései (1. B ábra)}

- A méh és kétoldali függeléke, a mellső vaginafallal együtt el lett választva a hólyagtól és így feldolgozva,

- a húgycső harántszeletekben,

- a hólyagalap szintén haránt irányban,

- a hólyagkupola a férfihólyag feldolgozással egyezően,

- a nyirokcsomók egészben, nagyobbak félbevágva mindkét nemben (2. táblázat ).

Ha a metszlapon fontosnak ítélt elváltozást találtunk, azt két szemközti metszési síkban is megjelenítettük. A szövettani leletezés a metszetek áttekintésének meghatározott sorrendjében történt, egy erre kidolgozott adatlap felhasználásával (2. ábra). A lelet szöveges formában összegezte a feldolgozó patológus véleményét (․ ábra).

2. ábra A makrometszetek kiértékelését segítő adatlap. Bal oldalon a sematikus, jobb oldalon a számszerüsített értékek megadásának lehetőségével

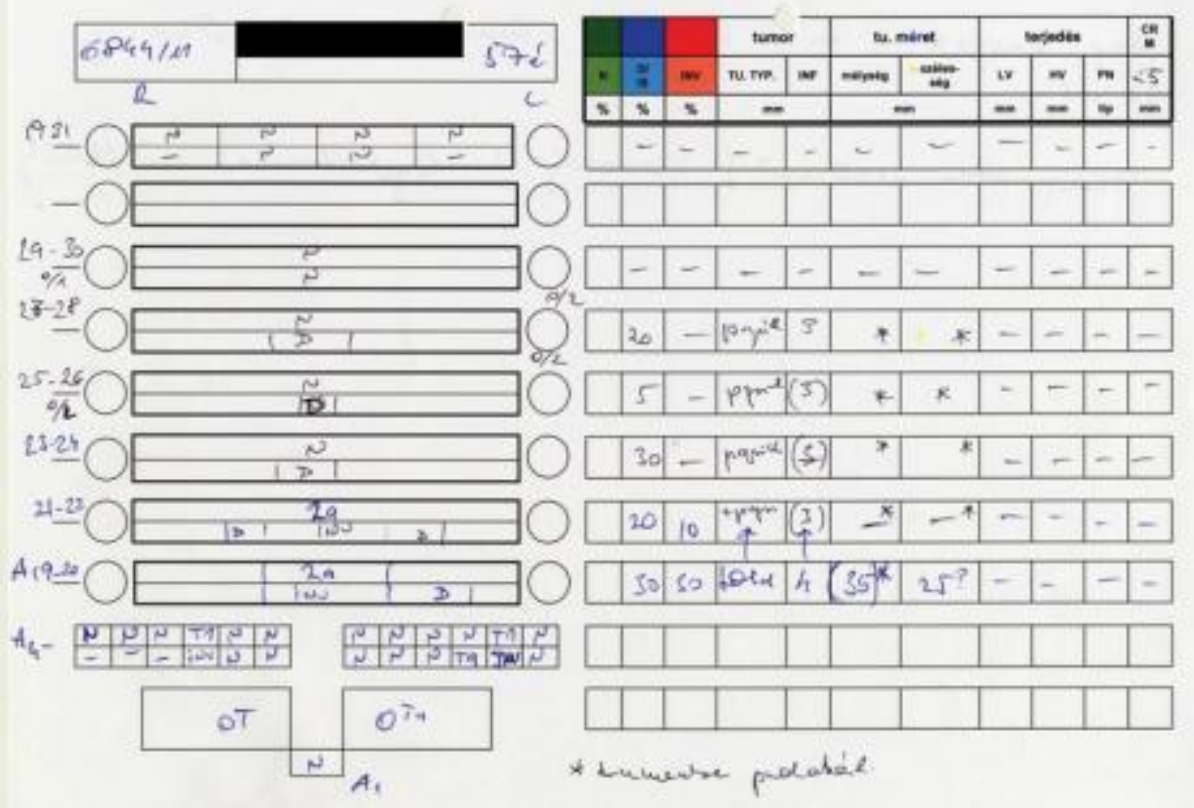

3. ábra A cystectomiás minta jelenlegi, legszélesebben alkalmazott kivágási protokollja

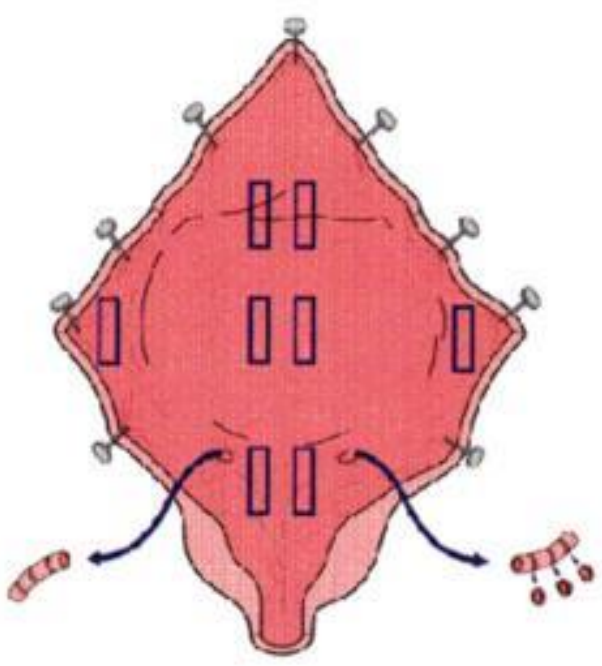

- Tumor

- Hólyagnyak

- Trigonum

- Mellsố fal

- Hátsó fal

- Kupola

- Mucosaeltérés

- Uréterszájadékok

- Uréter rez. vonal

- Prosztata

- Vesicula seminalis

- Összesen
3

1

2

1

1

2

1

2

2

8

2

25 


\section{Eredmények}

Az OKP-t a Szegedi Egyetem Pathologiai Intézetében 2008-tól napjainkig, minden radikális cystectomiás minta esetében, napi rutinfeldolgozásként alkalmazzuk. 2012 márciusáig összesen 138 vizsgálat történt. A 124 preparátum mérete átlagosan: superoinferior: 101,6 mm (legkisebb $40 \mathrm{~mm}$, legnagyobb $170 \mathrm{~mm}$ ). Medio-laterális: $92,7 \mathrm{~mm}$ (legkisebb $40 \mathrm{~mm}$, legnagyobb $140 \mathrm{~mm}$ ). Antero-posterior: 75,7 mm volt (legkisebb 35 mm, legnagyobb $130 \mathrm{~mm}$ ). 119 eset átlagos tömege: $308 \mathrm{~g}$ (legkisebb $46 \mathrm{~g}$, legnagyobb $680 \mathrm{~g})$.

A makroblokk $7 \mathrm{~mm}$ vastag hólyagfali és $5 \mathrm{~mm}$ legnagyobb vastagságú prosztata-szelet készítését tette lehetővé.

A hólyag, illetve a prosztata feldolgozásához átlagosan 9,2 db makroblokkot, valamint 14 standard blokkot használtunk fel. A férfiak radikális cystectomiája esetében átlag 9,82 db makro, 16,3 db standard blokkot készíttettünk (4. ábra). A nök cystectomiája esetében 8,76 db makro, 9,6 db standard blokkot használtunk fel (5. ábra).

A stádiumot a 2002-ben átdolgozott AJCC/UICC TNM rendszert használva határoztuk meg (2). Az eredményeket a 1. táblázatban mutatjuk be. Obturátor nyirokcsomó 126 esetben (91,3\%) került eltávolításra. Az eltávolított nyirokcsomók stádiumonkénti megoszlását és az áttétes nyirokcsomók arányát a 2. táblázat mutatja. Két esetben a nem

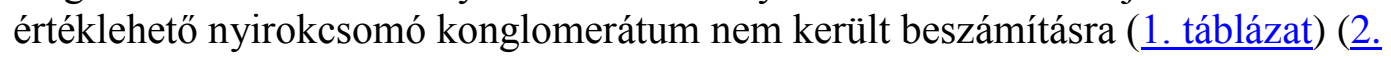
táblázat).

Egy makrometszet előállításának fogyóeszköz költsége: 1,8 euró, míg egy standard szövettani metszeté 0,25 euró volt. A férfi radikális cystectomia OKP szerinti feldolgozásának fogyóeszköz és vegyszer költsége átlagosan 21,8 euró míg a női cystectomiáké 18,2 euró volt. Egyszer beszerzendő eszköz igénye a rotációs mikroszkóp makro fej 1200 euró. A kivágás fotódokumentáció készítésével kettő, a mikroszkópos vizsgálat, további két patológusi munkaórát vett igénybe.

4. ábra Férfi radikális cystectomia OKP-lal feldolgozva. 12 sugárirányú kimetszés

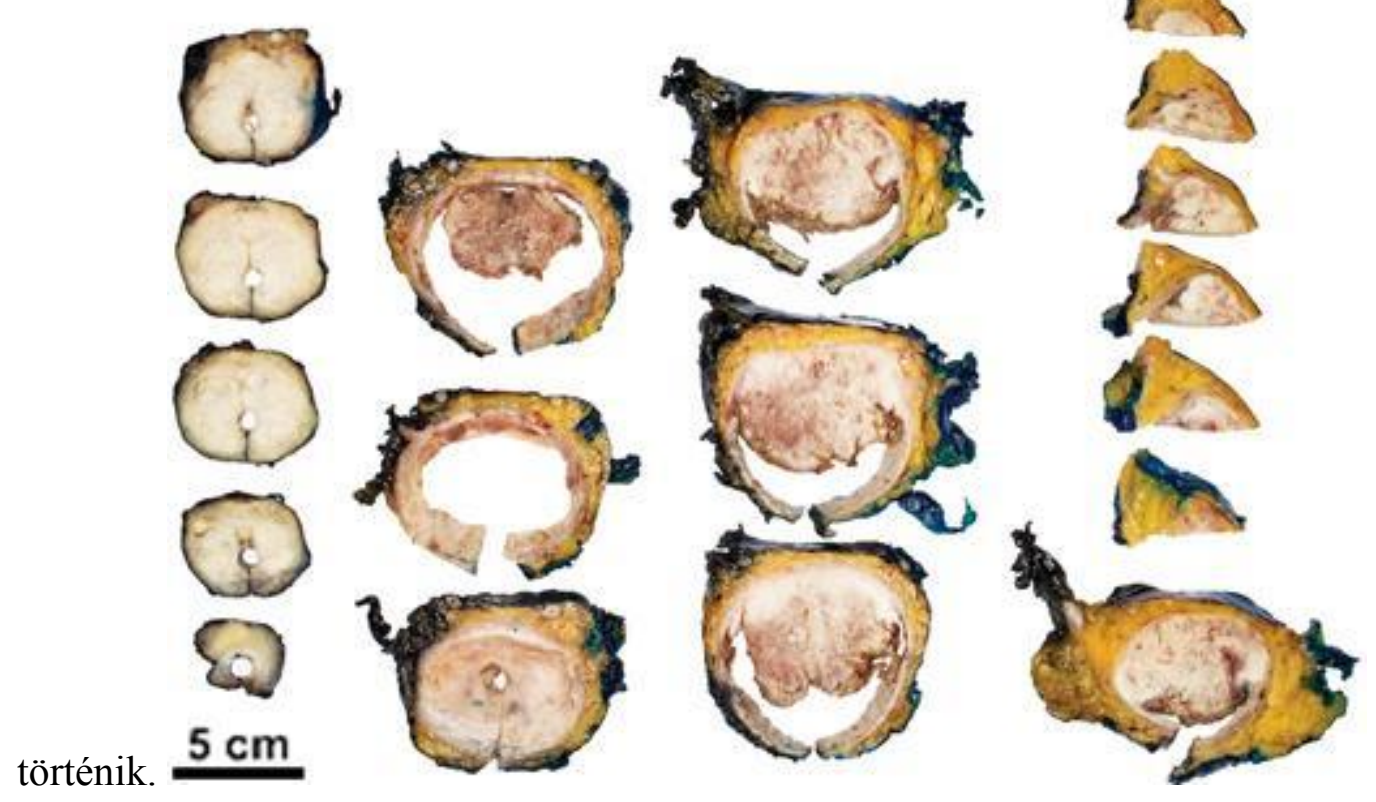


5. ábra A női cystectomia és hysterectomia feldolgozása harántszeletekben az uterus leválasztását követően

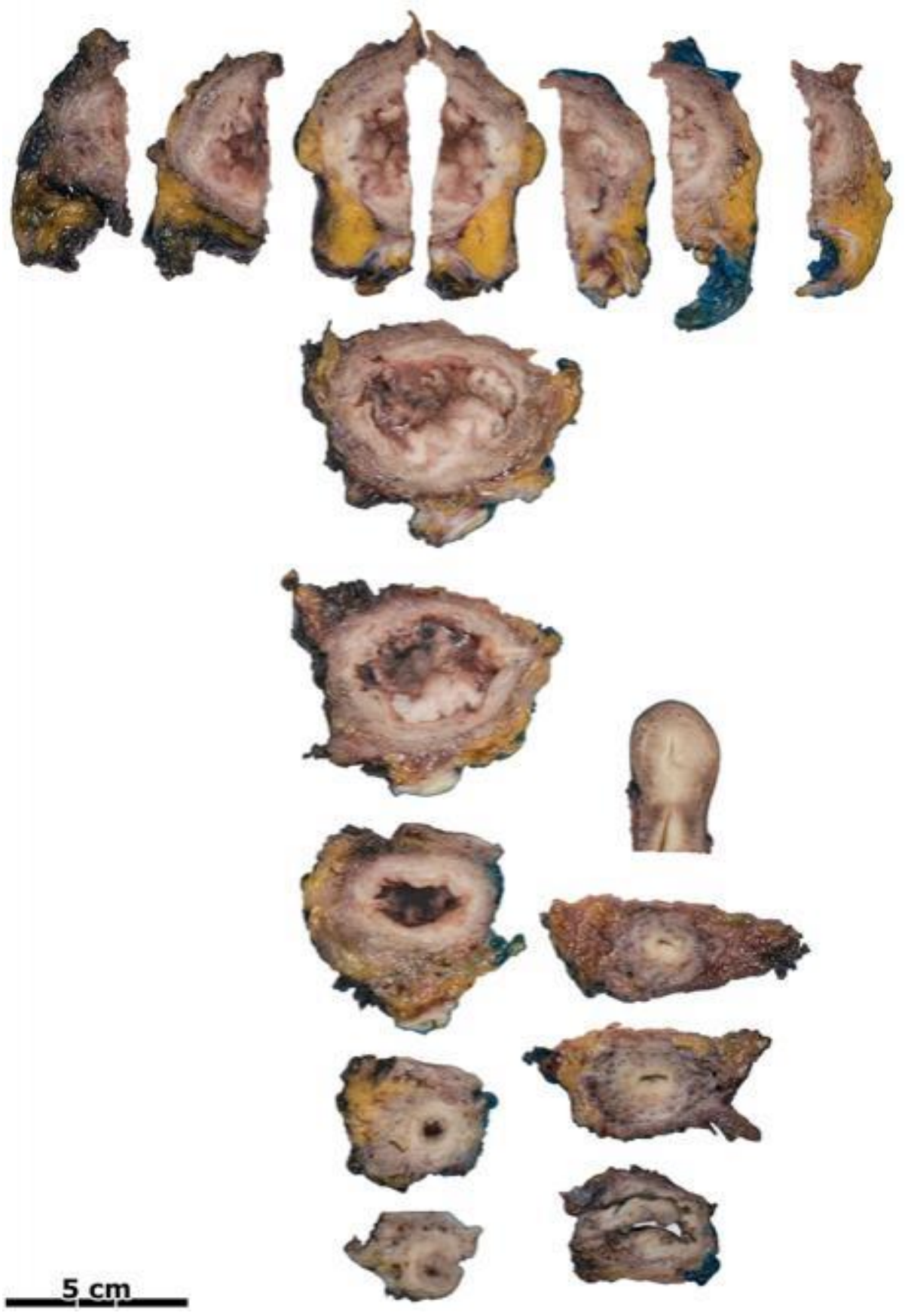


1. táblázat Az OKP szerint feldolgozott 138 radikális cystectomia stádium megoszlása

\section{STÁDIUM esetszám \%}

\begin{tabular}{lcc}
$\boldsymbol{p} \boldsymbol{T}_{\boldsymbol{0}}$ & 12 & 8,7 \\
$\boldsymbol{p} \boldsymbol{T}_{\boldsymbol{a}}$ & 1 & 0,72 \\
$\boldsymbol{p} \boldsymbol{T}_{i s}$ & 4 & 2,9 \\
$\boldsymbol{p} \boldsymbol{T}_{\boldsymbol{1}}$ & 21 & 15,22 \\
$\boldsymbol{p} \boldsymbol{T}_{2 a}$ & 13 & 9,42 \\
$\boldsymbol{p} \boldsymbol{T}_{2 b}$ & 16 & 11,6 \\
$\boldsymbol{p} \boldsymbol{T}_{3 a}$ & 21 & 15,22 \\
$\boldsymbol{p} \boldsymbol{T}_{3 b}$ & 27 & 19,56 \\
$\boldsymbol{p} \boldsymbol{T}_{4 a}$ & 18 & 13 \\
$\boldsymbol{p} \boldsymbol{T}_{4 b}$ & 5 & 3,62 \\
\hline
\end{tabular}

2. táblázat A stádiumonkénti eltávolított nyirokcsomók számát és áttétes érintettségét

mutatja

\begin{tabular}{|c|c|c|c|c|c|c|c|c|c|c|}
\hline & $\mathrm{pT}_{6}$ & $p T_{a}$ & $\mathrm{pT}_{\mathrm{is}}$ & $\mathbf{p} \mathbf{T}_{1}$ & $\mathbf{p} \mathbf{T}_{2 \mathrm{a}}$ & $\mathbf{p T}_{2 \mathrm{~b}}$ & $\mathrm{pT}_{3 \mathrm{a}}$ & $\mathrm{pT}_{3 \mathrm{~b}}$ & $p T_{4 z}$ & $\mathbf{p T}_{4 \mathrm{~b}}$ \\
\hline $\begin{array}{c}\text { Összes nyirok- } \\
\text { csomószám }\end{array}$ & 240 & 13 & 64 & 398 & 205 & 312 & 359 & 481 & 261 & 66 \\
\hline $\begin{array}{l}\text { Atlagos nyirok- } \\
\text { csomószám }\end{array}$ & 20 & 13 & 16 & 21 & 18,6 & 20,8 & 18 & 21 & 16,3 & 13,2 \\
\hline $\begin{array}{l}\text { Attétes nyirok- } \\
\text { csomók }\end{array}$ & $\begin{array}{c}13 \\
(1,5 \%)\end{array}$ & 0 & 0 & $\begin{array}{c}2 \\
(0,5 \%)\end{array}$ & $\begin{array}{c}14 \\
(6,8 \%)\end{array}$ & $(1,3 \%)$ & $\begin{array}{c}45 \\
(12,55)\end{array}$ & $\begin{array}{c}78 \\
(16,2 \%)\end{array}$ & $\begin{array}{c}57 \\
(21,8 \%)\end{array}$ & $\begin{array}{c}1 \\
(1,51 \%)\end{array}$ \\
\hline
\end{tabular}

\section{Megbeszélés}

A cystectomiás preparátum teljes feldolgozásának igénye a napi diagnosztika gyakorlata számára már több mint 10 éve felmerült. Hiszen könnyen belátható, hogy a makroszkópos kivágások között a daganat vagy daganatrész, esetleg daganat megelőző állapot rejtve maradhat. A húgyhólyagok egészben való feldolgozását először Soto és munkatársai végezték (3), összesen 45 esetben úgy, hogy a vizsgálat előtt a hólyagot celluloiddal 
töltötték fel. A szerzők többsége „térképezési” eljárást alkalmazott, azaz a preparátumot a húgycső hosszanti tengelye mentén felhasították és horizontális szeletekben dolgozták fel. A gyakran igen nagyszámú metszet áttekintése nehézkessé válik. Továbbfejlesztett változatban a hólyagot négy qudránsra osztották, így jobban kiteríthetővé vált. Az esetenként így keletkezett 5-100 kimetszés összeillesztése a szövettani feldolgozás után bonyolult lehet, ezért a részeket különbözö jelölésekkel látták el, és ezeket egybe illesztették (4). A középvonalban vezetett szagittális metszés utáni, két hólyagfél szövettani feldolgozása látványos és egy-egy közleményben, ilyen óriás blokkokról számolnak be (5). Nagyobb, a hólyag ürterébe bedomborodó daganatoknál ez a módszer technikailag szinte kivitelezhetetlen.

A cystectomiás minták rutin patológiai feldolgozását jelenleg Rosai és Ackerman kézikönyv összegzi (‥ ábra). Ezt alkalmazzák a legszélesebb körben, mert meghatározza a legfontosabb anatómiai helyeket, és elöírja, hogy a férfi hólyagból legalább 25 kimetszést kell végezni. Elgondolkoztató, hogy ebből csak három kimetszés reprezentálja magát a daganatot (13).

A jelentős számú cystectomiás OKP feldolgozás anyagunkban kiküszöbölte a makroszkópia vezérelte kivágás tévedési lehetőségét és teljes képet adott az anyagról. Rutin alkalmazása az anyagi és munka ráfordítás növelésével bevezethetővé vált. Nyilvánvaló előnyei leginkább bizonyos kritikus stádiumokban jelentkeztek. Például egyértelmüvé teszi a pT0 stádium kórismézését, hiszen biztosan nem marad tumor a kimetszés közötti részeken. Pontosan meghatározhatóvá vált az elkülönítés a pT2A és pT2B között. A belső és külső izomréteg tumoros infiltrációjának klinikai jelentősége még nem egyértelmü, és ennek egyik magyarázata, hogy a patológiai feldolgozás csak makroblokkos formában képes a pontos elkülönítésre $(6,7,8,9)$. A pT3A stádium szabad szemmel nem látható, így szerencsétlen esetben nem kerül a megfelelő rész a kivágásba, pedig klinikai jelentősége adott $(10,11)$. Az OKP talán legfontosabb értéke, hogy egyértelmüen meghatározhatóvá teszi a prosztata daganatos infiltrációját, a pT4A stádiumot, mert a két szomszédos szerv így egy szövettani metszetben vizsgálható (12). A stádiumtól függetlenül az OKP további adatok értékelését, számszerüsítését is biztosíthatja:

- a tumor mértékének háromdimenziós meghatározását,

- a daganat teljes heterogenitásának feltérképezését,

- az infiltráció mélységének és mintázatának megrajzolását,

- a cirkumferenciális reszekciós vonal pontos meghatározását,

- valamennyi vaszkuláris és perineurális terjedés azonosítását,

- a dysplasia és in situ carcinoma kiterjedésének kimutatását.

Az OKP sajnos költség- és munkaigényesebb, mint a kimetszéses feldolgozás. Az anyagköltség háromszor, négyszer is meghaladja az eddigi kiadásokat. A patológus munkája speciális gyakorlatot, türelmet és jelentős ráfordítást igényel.

\section{Következtetések}

A cystectomiás preparátum szövettani feldolgozása során a makroblokkos technika alkalmazásának módszere - az orientált kivágási protokollal - lehetővé teszi a daganat minden részletének feltárását. A módszer hazánkban is megvalósítható, bár költség- és munkaigényes. 


\section{Köszönetnyilvánítás}

Sükösd Farkast az Európai Unió HUSRB/1002/214/126 pályázata támogatta. A fotókért és a grafikai munkáért Dezső Mihályt illeti köszönet.

Irodalomjegyzék: 1. Cheng L, et al. Staging and reporting of urothelial carcinoma of the urinary bladder. Mod Pathol 2009; 22 (Suppl 2): S70-95.

2. Greene FL, et al. American Joint Commitee on Cancer Staging Manual. Springer Verlag; New York: 2002.

3. Soto EA, Friedell GH, Tiltman AJ. Bladder cancer as seen in giant histologic sections. Cancer 1977; 39 (2): 447-455.

4. Hind A, et al. Histopathological study of 110 cystectomy specimens for bladder cancer by an original mapping method. J Exp Clin Cancer Res 1998; 17 (1): 59-64.

5. Sekine H. A study of dysplasia associated with bladder cancer - histopathological findings of bladder giant sections and related urinary cytology. Nihon Hinyokika Gakkai Zasshi 1989; 80 (4): 545-554.

6. Jewett HJ. The historical development of the staging of bladder tumors: personal reminiscences. Urol Surv 1977; 27 (2): 37-40.

7. Cheng L, et al. Tumor size predicts the survival of patients with pathologic stage T2 bladder carcinoma: a critical evaluation of the depth of muscle invasion. Cancer 1999; 85 (12): 2638-2647.

8. Boudreaux KJ, et al. Comparison of american joint committee on cancer pathological stage T2a versus T2b urothelial carcinoma: analysis of patient outcomes in organ confined bladder cancer. J Urol 2009; 181 (2): 540-545. discussion 546.

9. Tilki D, et al. Validation of the AJCC TNM substaging of pT2 bladder cancer: deep muscle invasion is associated with significantly worse outcome. Eur Urol 2010; 58 (1):

$112-117$.

10. Scosyrev E, Yao J, Messing E. Microscopic invasion of perivesical fat by urothelial carcinoma: implications for prognosis and pathology practice. Urology 2010; 76 (4): 908913. discussion 914.

11. Dalbagni G, et al. Cystectomy for bladder cancer: a contemporary series. J Urol 2001; 165 (4): 1111-1116.

12. Shen SS, et al. Prostatic involvement by transitional cell carcinoma in patients with bladder cancer and its prognostic significance. Hum Pathol 2006; 37 (6): 726-734.

13. Rosai And Ackerman's Surgical Pathology 10th ed. Edited by Juan Rosai. MO: Mosby; St. Louis: 2011. 2913-2914. 
Publication II. 


\title{
Accurate Determination of the Pathological Stage with Gross Dissection Protocol for Radical Cystectomy
}

\author{
Farkas Sükösd • Béla Iványi • László Pajor
}

Received: 5 September 2013 /Accepted: 6 February 2014/Published online: 23 February 2014

C) Arinyi Lajos Foundation 2014

\begin{abstract}
The current protocol for reporting urinary bladder cancer in radical cystectomies may exhibit limitations in the diagnostic accuracy, such as a risk of understaging, especially in cases with prostatic involvement. Difficulty can arise in the verification of stage $\mathrm{pT} 0$, and the assessment of surgical margins is suboptimal. We have developed a daily gross dissection protocol practice where radical cystectomies are totally embedded and evaluated histologically in wholemount sections. We report here on the first 138 consecutive specimens from 2008 to the first quarter of 2012 inclusive. The incidence of the cancer stages was compared with data on 15,586 radical cystectomies from the literature. The differences were analyzed with the one-sample z-test $(p<0.05)$. The following emerged from and our series and the literature data: pT0 $8.7 \%$ and $6.1 \%$; pTa $0.7 \%$ and $2.9 \%$; pTis $2.9 \%$ and $6 \%$, pT1 $15.2 \%$ and $15.5 \%$, pT2 $21 \%$ and $23.3 \%$; pT3 $34.8 \%$ and $34.3 \%$, and pT4 $16.7 \%$ and $11 \%$, respectively. Our findings closely reflected the means of the published statistical data based on a large number of cases. The differences were due to the more detailed processing: the case numbers in groups from pTis to $\mathrm{pT} 2$ were comparatively low, while those in groups pT3 and pT4 were higher. The difference in group $p T 4$ was significant $(p=0.0494)$. With this method, only those samples were regarded as $\mathrm{pT} 0$ in which the granulomatous area and the hemosiderin deposition
\end{abstract}

Electronic supplementary material The online version of this artick (dox:10.1007/s12253-014.9748-z) contains supplementary material, which is available to authonized users.

F. Sülō̌sd () · B. lvínyi

Department of Pathology, Faculty of Medicine, University of Szeged,

2 Allomis u., Szeged, Hungary 6720

eबmail: sukosd.farkas@med.u-szeged.hu

L. Pajor

Department of Urology, Faculty of Medicine, University of Szeged,

57 Kallvána u, Szeged, Hungary 6725 indicative of the earlier intervention were observable and the entire preparation was tumor-free.

Keywords Cancer stage - Gross dissection - Pathology report - Radical cystectomy · Total embedding - Urinary bladder carcinoma . Whole mount section

\section{Introduction}

The incidence of bladder tumour has been rising during the past two decades. In 2002, 357,000 new cases were registered globally by WHO [1], making bladder tumour the fourth most common tumour type in men and the eighth in women. The treatment for the muscle-invasive tumour (T2-4) is radical cystectomy. One hundred seventy-two operations of this type were perfomed in Hungary in 2010.

The most important information for clinical decisions regarding advanced bladder tumour and the prognosis is the stage of the tumour [2]. In nearly half of the cases, the clinical stage does not match the post-surgical assessment based on histopathological examination [3]. However, the result of the pathological examination is at present decisive for the planning of the postoperative therapy and for the prognosis $[2,4,5]$.

The most important step in the pathological examination is the selection of the areas to be processed for microscopic scrutiny, because these areas will be regarded as representative of the entire tumour, and will be studied in detail, subjected to immunohistochemistry and discussed in consultations. In striking contrast with the often traditional archivation requirement of embedded parts, tissue parts not deemed worthy of dissection are irrevocably destroyed.

The guidelines for the gross dissection of pathological samples are considerably more recent than microscopic examinations themselves. Consequently, their system of criteria 
Table 1 The distribution of 15,586 pathological staging data on 27,394 pablished radical cystectomies

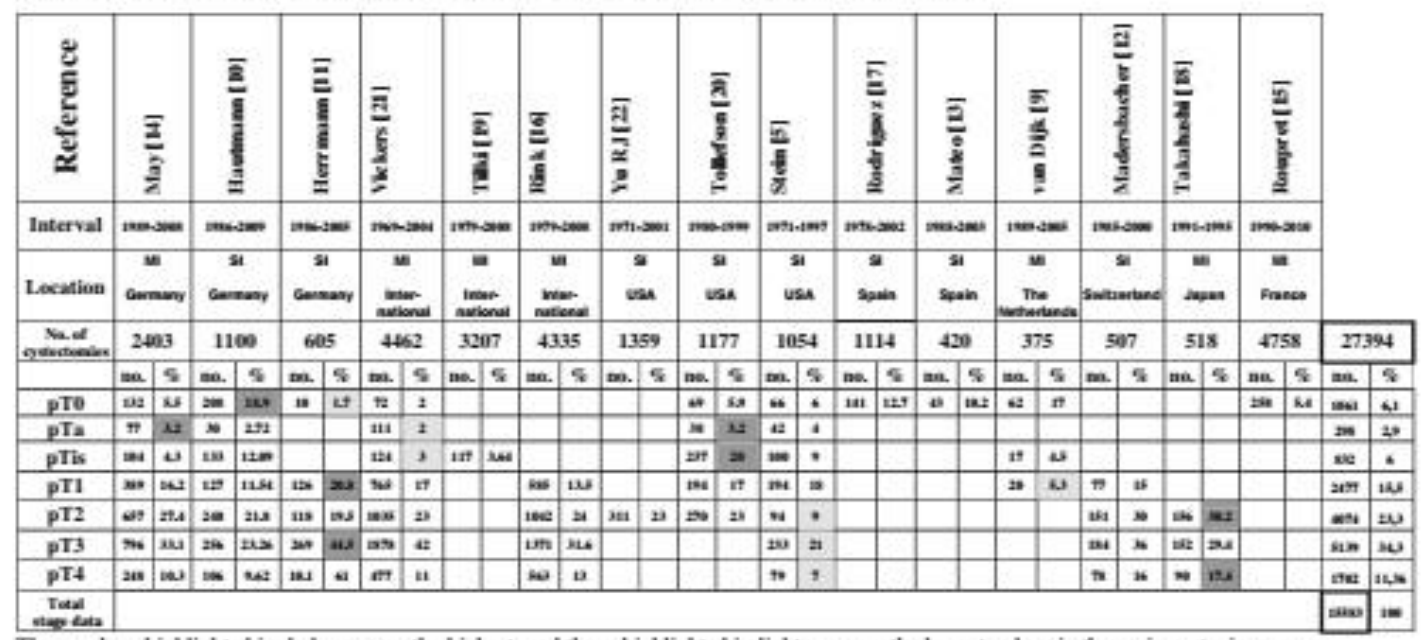

The mumbers highlighted in dark-gray are the highest, and those bighlighted in light-gray are the lowest values in the varives staging groups

Abbroviatious: MI multivinstitute, SI single institute

is not as mature as that of the latter. The first set of gross dissection guidelines conceming a urinary bladder removed because of cancer was printed 55 years ago [6]. A number of manuals have subsequently been published as the system has undergone development. These manuals are unifom in that they enumerate the areas of the preparation deemed important to be cut, but do not elaborate on the mode [7], whereas the mode of dissection and the positioning of eertain organs, such as the uterus, cervix, fallopian tube, appendix and skin, have been meticulously regulated [8]. The objective of all such guidelines is to reduce the subjectivity of the pathologist.

The reported incidences of certain stages identified in cystectomy samples exhibit considerable variation [5, 9-22] (Table 1), and we consider that a major factor underlying this variation is the insufficient standardization of the pathological processing of the cystectomy samples.

In view of the importance of the pathological opinion $[2,4]$, we have developed a Gross Dissection Protocol for
Fie. 1 Schematic representation of the Gross Dissection Protocol for Rafical Cystectony (GDPRC) for male (a) and female (b) cystectomies. 1: urethral resection line and prostatic apex. 2: prostate cross-sectivens with wider back part of lobes. 3: 12 radial cuts from the bladder. prostate busal block (BB) 4: bladder macro crossesections. 5 ; sagittal sections of the dome. $5 \mathrm{a}$. frontal processing of the lateral sagittal section in cases of dome involvement. Colour coding: pink: mucoss; reat muscle layer, gry? resectiva margin; willow: glandalar tissue

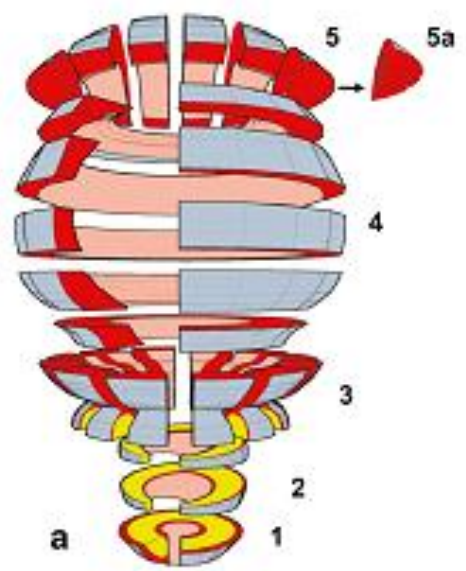

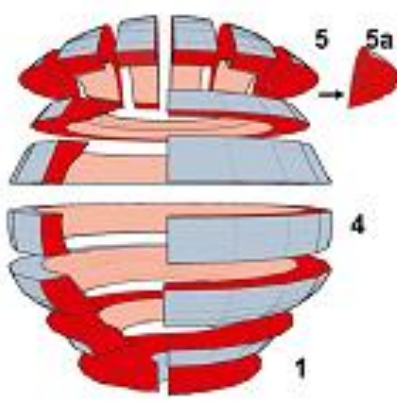

b

\section{Q Springer}




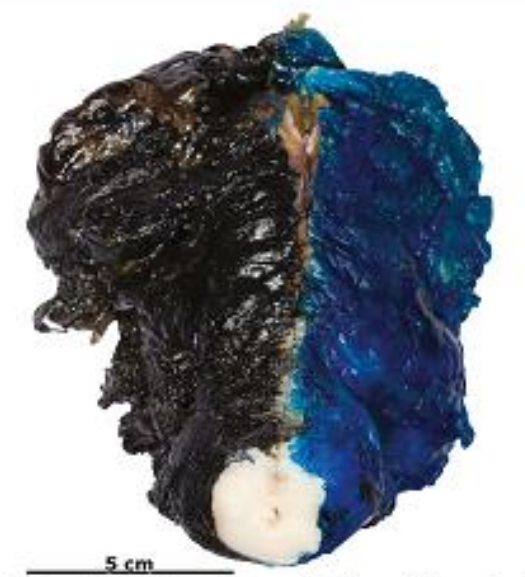

Fig. 2 Orientational incision and removal of the unethral resection level and prostate apex after side marking (kffi side bhene, right side black) of a male cystoprostatectiony preparation

Radical Cystectomy (GDPRC) and introduced it into our daily routine. Our objective in this was to improve the European recommendation [7] by utilizing the potential of the commercially available macroblock technique. In this paper we describe the steps of dissection, embedding and microscopic evaluation in the processing of radical cystectomy samples.
We then compare our results with data reported in 15 publications on 15,586 stages identified in 27,394 cystectomies. We also comment on the financial and workload aspects of the procedure.

\section{Patients and Methods}

\section{Patients}

From 2008 to the first quarter of 2012, 138 radical cystectomies were performed at our Department of Urology. The consecutive samples were histologically processed whole, using macroblocks. The samples had been taken from 99 men to 39 women. The average age was 62.3 years; that of the men was 64.0 years (range $41-76$ ), while that of the women was 60.6 years (range 49-71).

\section{Pathological Evaluation with GDPRC}

The steps of the processing and histological evaluation are described in detail in the Electronic Supplement. Briefly, the samples are fixed in $10 \%$ formalin without dissection, for a minimum of 3 days. The cutting procedure of the cystectomy preparation is outlined schematically in Fig. 1 . An anteriot orientational incision is made (Fig. 2). Male and female bladders are further processed with different cutting steps (Figs. 3, 4, and 5):
Fig. 3 Due to anteflexion of the axes of the prostate and the bladder the transverse resectio level of the urethra and the bladder-prostate busal block (BB) bladderpmotat basal block (BB) are not paralle (a). The wedgeshupoul cross section made from the prostate (b) yields a BB enclosed by parallel planes (c)

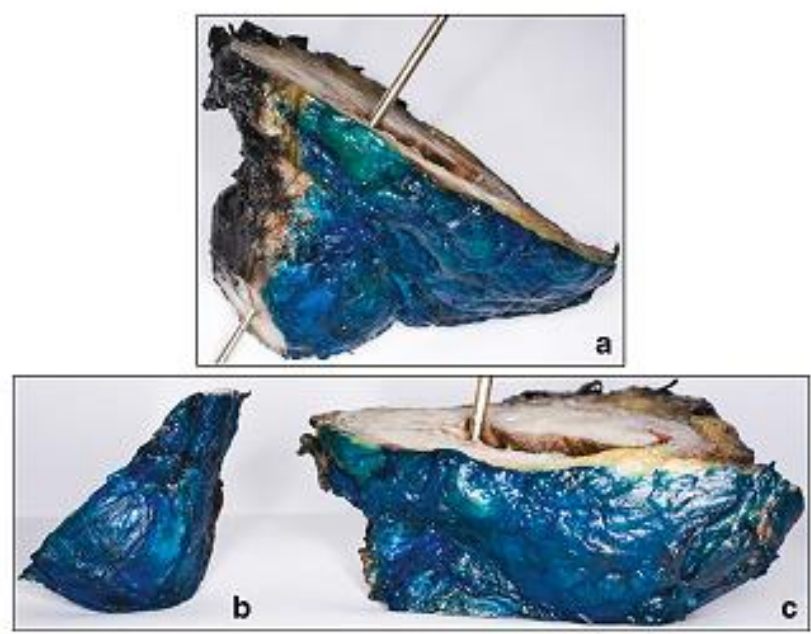


Male bladder

1. A cross-section of a urethral resection line

2. Wedge-shaped section of the prostate

3. Construction of a bladder-prostate basal block (BB), including the bladder base and the prostate base

4. 12 radial sections from the $\mathrm{BB}$

5. Cross-sections above the BB

6. The bladder dome in sagittal parallel levels

7. Seminal vesicle embedding

Fomale bladder

1. The uterus, appendages and vaginal wall are separated

2. Cross-sections of the urethral resection level and the bladder

3. The bladder dome in sagittal parallel levels

4. The uterine cervix below the peritoneal pouch in cross-sections

5. The uterine cervix, corpus and bilateral appendages according to the current internationally applied procedural protocol.

6. The vaginal stump in parallel sections

The GDPRC is implemented in a flexible fashion. The most frequent modification is visualization (reflection), in two cutting levels, of the lesion observed on the cutting surface (Fig. 5). Lymph node regions are generally embedded whole; the larger ones are halved.

Histological evaluation is carried out by using a standardized report form (Fig. 6) and presented in a written form.

Statistical Analysis

Stages were determined with the AJCCIUICC TNM system as revised in 2002 [23]. The frequencies of the individual stages were expressed as percentages. Differences were evaluated using the one-sample z-test. A $p$ value $<0.05$ was considered to indicate a significant difference between groups.

\section{Results}

Data of Staging and Dimensions

The GDPRC has been applied as the daily routine processing procedure for all radical cystectomy specimens in our Department of Pathology since 2008. Up to March 2012, a total of 138 examinations were completed. The results are shown in Table 2. Obturator lymph nodes were removed in 126 cases $(91.3 \%)$. The distributions of removed lymph nodes by stage and of metastastatic lymph nodes are presented a
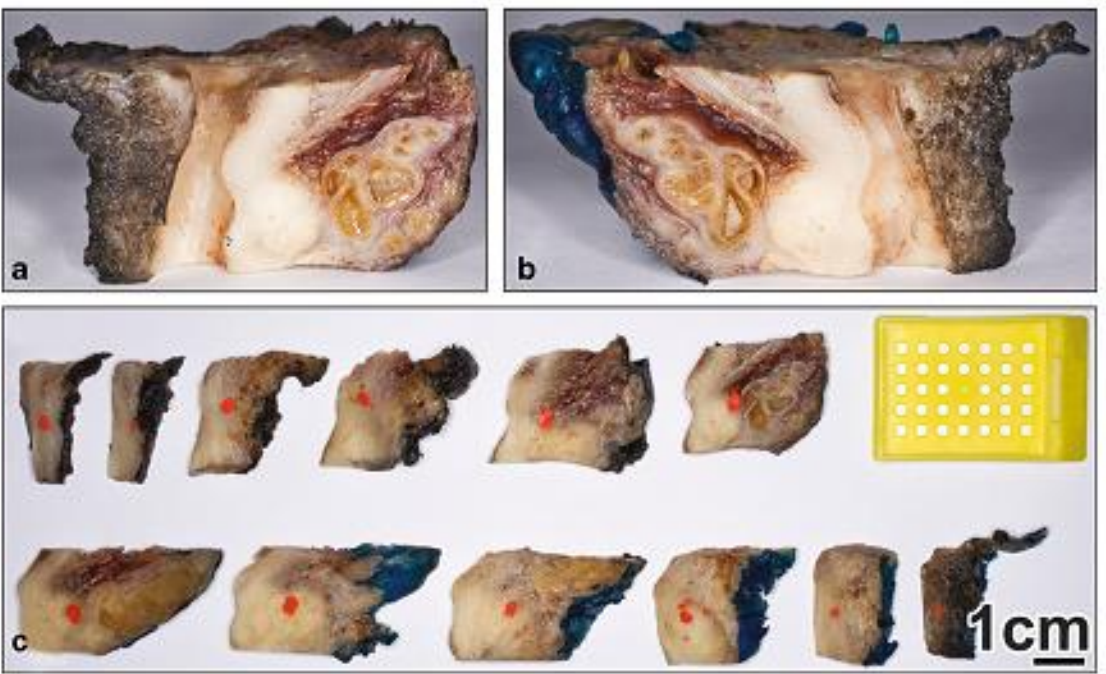

Fig. 4 . Processing of the BB. The right (a) and the left (b) portions are shown affer completion of the crientational incision. The orientational incision entering all the way to the urethra is greatly distorted and

coloured blackish by black ink marking, this ensures orientation in the sections. The 12 radial cuthoffs can be placed into standard cassettes. Rod staining indicates the surface to be micro-sectioned 


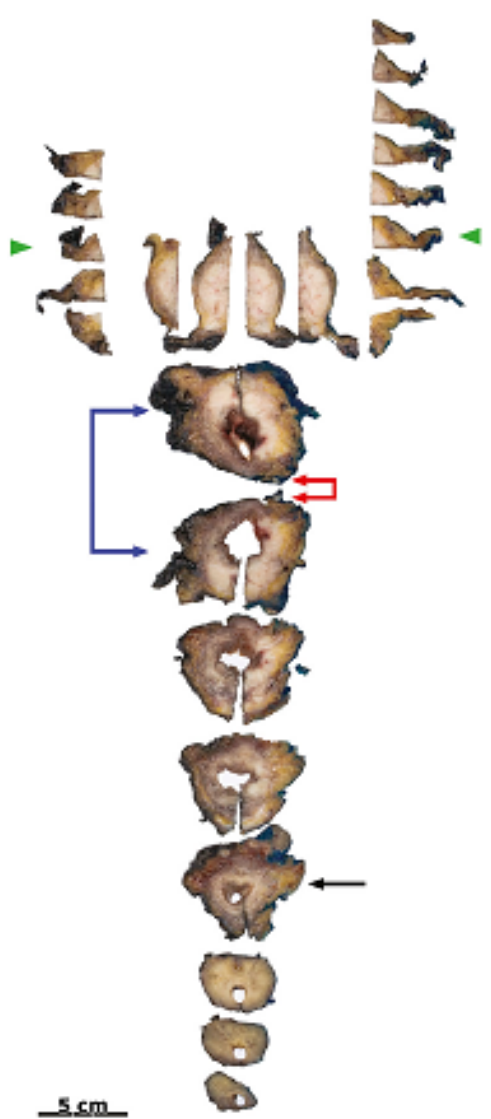

Fig. 5 Male cystoprostatectomy with GDPRC The amow indicates the $\mathrm{BB}$ from which 12 radial cut-outs serve for the evaluation of the bladder buse and the prostate base. The amowhead show the frontal processing of the sagittal cross-sections serving for the evaluation of the lateral portion of the dome. The bluc dowble amow shows a reflective cutting surface on which there is foreign tissue (nod dowhle amow) in the posterior surgical margin

in Table 2. In two cases, an unevaluable lymph node conglomerate was not included.

The average sizes of the 124 preparations were: superoinferior $101.6 \mathrm{~mm}$ (range $40-170 \mathrm{~mm}$ ); medio-lateral $92.7 \mathrm{~mm}$ (range 40-140 mm); and antero-posterior $75.7 \mathrm{~mm}$ (range $35-130 \mathrm{~mm}$ ). The average mass of 119 specimens was $308 \mathrm{~g}$ (range $46-680 \mathrm{~g}$ ).

The macroblock allowed the preparation of bladder wall sections $7 \mathrm{~mm}$ in thickness and prostate sections $5 \mathrm{~mm}$ in maximum thickness.

\section{Material Input and Costs}

On average, 9.2 macroblocks and 14 standard blocks were used for the processing of the radical cystectomy samples. In cases of cystoprostatectomy, an average of 9.8 macroblocks and 16.3 standard blocks were prepared. In cases of cystectomy of female patients, 8.8 macroblocks and 9.6 standard blocks were used. The cost of the consumables used for the preparation of a macrosection was $€ 1.88$, whereas that of a standard histological section was $€ 0.25$.

The average cost of the consumables and chemicals used up for the GDPRC processing of a male radical cystectomy specimen was $€ 21.8$, and that of a female one was $€ 18.2$. A necessary one-time purchase was that of a macro head for the rotating microtome (Thermo Shandon Finesse ME+ Code Nr: 77510167): \& 182.76.

Dissecting with photographic documentation took $2 \mathrm{~h}$ and microscopic examination 2 additional hours of the pathologist's time.

\section{Discussion}

The current intemational gross dissection guidelines for radical cystectomy list the anatomic site deemed sufficiently important to be examined and leave it to the pathologist to select (somewhat at random) the areas that may be expected to contain microscopic lesions. When only minimally required samples are considered, at least 27 cuts have to be made on a male bladder, however, only three of these will originate from the tumour. The urethra and its resection line are not even mentioned in the list. This method is of only limited value, especially in the case of formalin-fixed samples [24]. The GDPRC performs the examination on macrosections (Fig. 7), eliminating the subjectivity originating from dissection, the most critical step of pathological processing; the procedure is adapted to the conditions of the daily routine, with the possibility of intervention kept open.

\section{The GDPRC Allows the Determination of Stage pT0}

In the absence of suspicious macroscopic signs or data regarding the localization of earlier interventions, there is no guidance as to how to make the gross dissection. If the first gross dissection showing tumour negativity was made in a nonoriented fashion, subsequent cuttings can only be incidental and no guidance whatsoever is available as concerns their mode, extent or number. In the course of the GDPRC, only those samples were regarded as pT0 resections in which the granulomatous area and the hacmosiderin deposition indicative of the earlier intervention were observable and the entire preparation was tumour-free. 


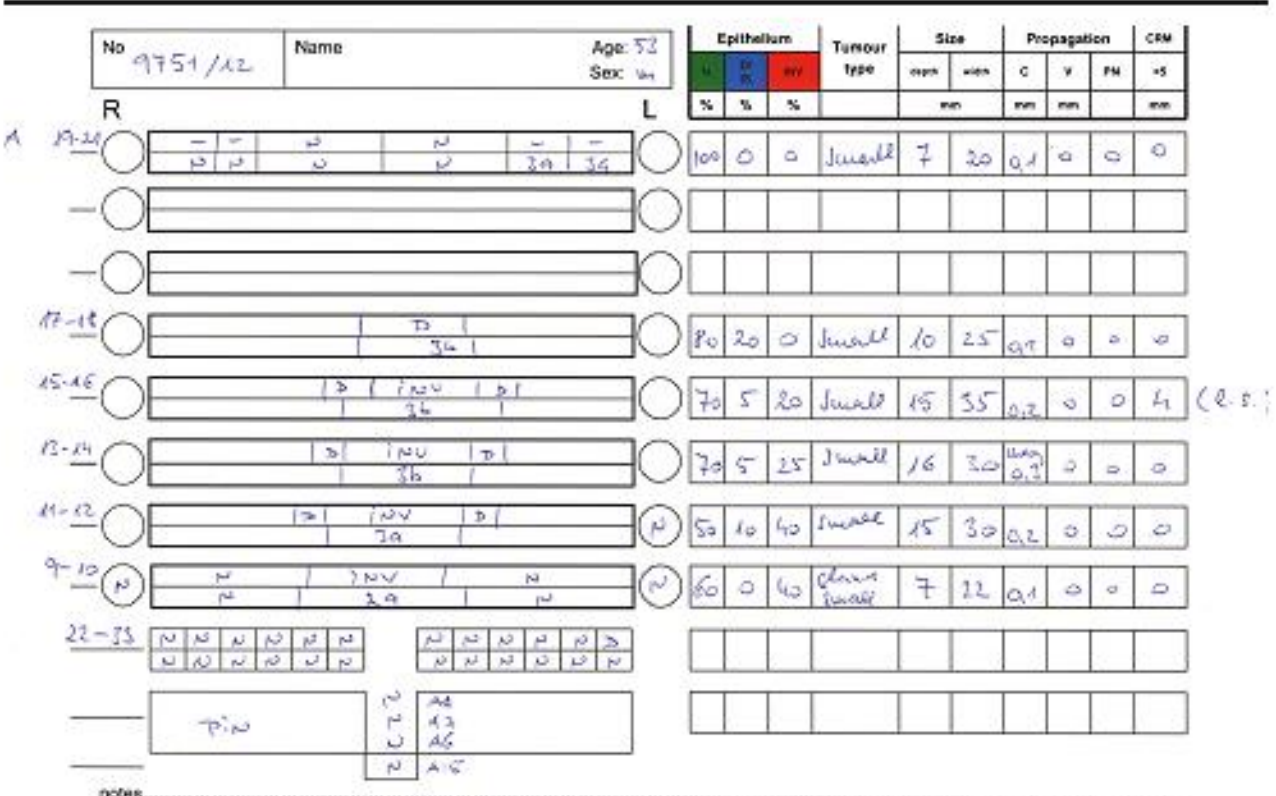

Fig. 6 An example of the report form relating to the evaluntion of macro slides. The lefi side serves for schematic information and the right side for the reconding of numerical data (see Electronic Supplement)

The GDPRC Allows the Precise Determination of $\mathrm{pT} 2$ Subcategories

The practicability of $\mathrm{pT} 2$ subcategories has recently been at the focus of intensive debate. Jewett based his classification of muscle-invasive tumours into internal and external layers on autopsies of 107 patients who had died as a consequence of bladder cancer, and the TNM system adopted that classification [25]. In contrast, American authors who followed up 123 muscle-invasive tumours failed to observe any difference between the suggested pT2 subcategories, and therefore suggested their elimination [26]. A recent international study based on 565 cases, however, evaluated the TNM system as practicable [27]. The settlement of the dispute is made more difficult by the fact that the aggressively infiltrating tumours that exhibit tentacular spread cannot be perceived visually or by palpation. Nor can imaging techniques be applied, since they do not offer microscopic resolution. A non-oriented cut therefore makes an evaluation of the infiltration depth uncertain. In the course of the GDPRC, simultaneous preservation of the localization and dimensions of the infiltrating area and its relationships with the surrounding tissues are ensured.

\section{The GDPRC Identifies Stage pT3a with Certainty}

Even theoretically, the current dissection procedure performed with the naked eye can detect extra-organ expansion only incidentally. This circumstance may have contributed to the failure of numerous reports to find differences between stages

Table 2 The pathological stage distribution in 138 mdical cyslectomy assessments with the GDPRC, and the hymph node involvement per stage

\begin{tabular}{llllllll}
\hline & $\mathrm{pT0}$ & $\mathrm{pTa}$ & $\mathrm{pTis}$ & $\mathrm{pT1}$ & $\mathrm{pT2}$ & $\mathrm{pT3}$ & $\mathrm{pT4}$ \\
\hline No. of cases (\%) & $12(8.7)$ & $1(0.7)$ & $4(2.9)$ & $21(15.2)$ & $29(21)$ & $48(34.8)$ & $23(16.7)$ \\
Total no. of lymph nodes & 240 & 13 & 64 & 398 & 517 & 840 & 327 \\
Average no. of lymph nodes average & 20 & 13 & 16 & 21 & 39.4 & 39 & 29.5 \\
No, of motastatic hymph nodes & $13(1.5 \%)$ & 0 & 0 & $2(0.5 \%)$ & $18(8.1 \%)$ & $123(28.7 \%)$ & $58(23.3 \%)$ \\
\hline
\end{tabular}


Fig. 7 Macro cut-out with the projection of the macro slide projection of the mate slide tumour is indicated by dots

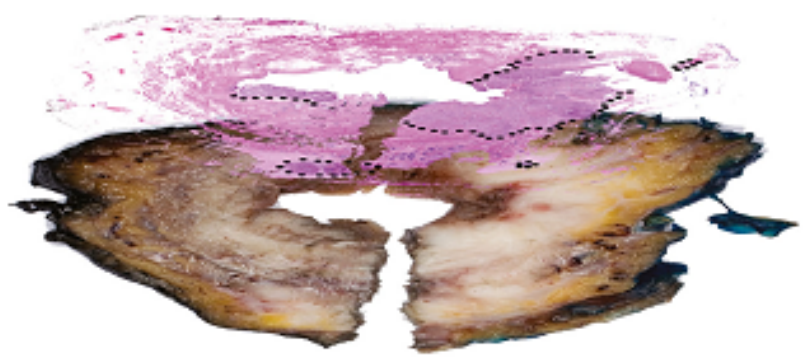

pT2 and pT3a or pT3b. The validity of the subcategorization of stage pT 3 has been verified on the basis of a large number of cases $(n=2,388)$, supporting the practicability of the present TNM system [28]. The GDPRC permits the identification and localization of the extravesical spread and the measurement of its dimensions.

The GDPRC Allows the Precise Identification of Stage pT4a and the Route of Prostate Infiltration

In consequence of the formalin fixation, tumour infiltration into the dense tissue of the prostate (stage pT4a) is most often invisible to the naked eye. The route of infiltration, which may occur by breaking through the entire thickness of the bladder wall or via the urethra is of prognostic significance, but no guidance is available as to the method of examination of prostate infiltration. Donat et al. studied specimens cut into 3-mm-thick sagittal sections [29]. However, in this way the urethra can be represented in only one or two levels, whereas this organ may be not only a route of infiltration, but also a primary tumour site. Another possibility is the separation of bladder and prostate, and the processing of both according to the protocol corresponding to the primary cancer of the given organ [30]. The GDPRC offers the possibility of the microscopic study of both organs in one section. On the 12 radial cuts of the $\mathrm{BB}$, the $3 \mathrm{D}$ measurements and circumferential resection distance can also be determined. This is important, because this is regarded as the nearest resection margin.

\section{Processing of the Prostate and the Urethra by GDPRC}

The entire prostate below the BB is studied in macrosections, in compliance with the literature recommendation [31]. However, since the prostatic urethra runs in an anteriorly open angle, the cross-section plane of the urethral resection margin and the plane of the BB form a triangular section (Fig. 4b). In order to retain all surgical edge markings in the sections, further cuttings were also performed at an angle. (The reason why this is not the case in prostatectomy specimens is that the urethral resection lines are not taken into consideration during
Fig. 8 The incidences of the various puthological stages in radical cysoctomy. Red in malical cyso thom Rod num denose the averages of the literature data nlack numbers are the extremes of the published data. Green numbers denote the incidence data as assessed with the GDPRC. The difference between the published data and those determined with the GDPRC for stage $\mathrm{pT} 4$ is statistically significant

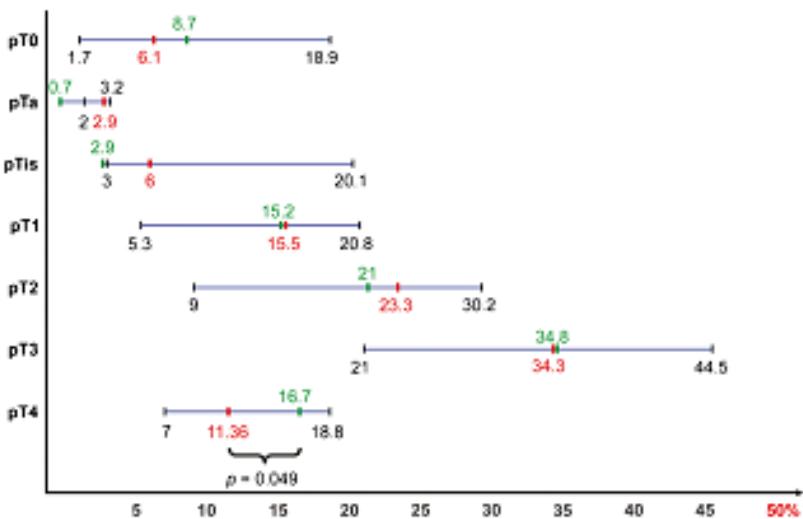


the preparation, because it is not our aim to obtain complete cross-sections of those parts.) When the urethral stump was involved, we assessed the resection margin distance in sagittal cross-sections after re-embedding.

Comparison of the Stage Distribution as Assessed by the GDPRC with the Literature Data

The incidences of the pathological stages of cystectomies exhibit significant differences even within the same geographical region and time interval, even when the tests performed prior to cystectomy and the surgical indications are nearly identical. Nevertheless, the incidence determined on the basis of a large number of cases must reflect the actual incidence. We therefore carried out determinations by using the data on 15,586 stages of 27,394 cystectomies presented in 15 publications from the period between 1971 and 2010 (Table 1) [5, 9-22].

The relatively small number of cases processed with the GDPRC quite accurately reflected the statistical data based on a large number of cases (Fig. 8). The differences observed are due to the more detailed processing. the case numbers in the pTis-pT2 groups were found to be lower, while those in groups pT3 and pT4 were higher. In the case of pT4, the difference was significant ( $11.36 \%$ vs. $16.6 \%, p=0.0494)$. We consider that the more frequent occurrence of cases in the highest stage may provide a partial explanation for the inaccurate prognosis of cystectomies.

The incidence of pT0 among the cases we studied was higher than the average of the published data $(8.7 \%$ vs. $6.1 \%$ ). The reason for this may be that the histological examination of preoperative TUR cannot provide a reliable evaluation of the completeness of tumour removal, and the resolution of imaging techniques is at its worst with small tumours. The surgical indications for this stage are therefore more uncertain, and are unsuitable for a well-founded comparison.

\section{Further Possibilities in the GDPRC}

The GDPRC may be additionally utilized to evaluate further prognostic factors, such as:

1. microscopically measured tumour dimensions and surgical margins;

2. vascular and perineural infiltrations;

3. accompanying urothelial dysplasia/in situ carcinoma:

4. tumour heterogeneity and infiltration pattem.

5. The GDPRC opens the way to the digital processing of data and to comparison with the findings of imaging techniques.

\section{Limitations of the GDPRC}

The GDPRC is more labour-intensive and more expensive than the present protocol. Current processing requires 27 standard cassettes with a minimum cost of $€ 6.75$ $(27 \times \in 0.25)$. The cost of consumables applied in the GDPRC for male bladders are therefore 3.5 times higher and for female bladders three times higher.

Macro slide preparation requires practice for the preparation of 4-6- $\mu \mathrm{m}$ thick sections. The staining is not automatized. The GDPRC is labour-intensive for the pathologist. Gross dissection with photographic documentation takes $2 \mathrm{~h}$, and histological evaluation an additional $2 \mathrm{~h}$

The 7-mm-thick macroblock cross-section is a reasonable compromise in exchange for not having to inflate the bladder before fixation, or to submit it to special preparative procedures under clinical conditions.

The GDPRC is not suitable for the processing of atypically resected samples.

In summary, use of the GDPRC can minimize the level of subjectivity during pathological examinations of radical cystectomies. The definition of pT0 is unambiguous and assessments of the higher stages become more certain. Stage pT4 proves to be more frequent than currently believed.

Ackmowledgments The authors thank Mihally Desso for the photography and graphical work, and Dr. Tibor Nyiri for help with the statisticel analyses. Supported by TAMOP-4.2.2 A-1 L/1/KONV-2012-0035.

\section{References}

1. Parkin DM (2008) The global burden of urinary bladder cancer. Scand J Urol Nephrol Suppl (218)42:12-20

2. Cheng L, Montironi R, Davidson DD, Lopez-Beltran A (2009) Staging and reporting of urothelial carcinoma of the urinary bladder. Mod Pathol 22(Suppl 2)-S70-\$95

3. Herr HW (1992) Staging invasive bladder tumors. J Surg Oncol 51: $217-220$

4. Shariat SF, Palapattu GS, Karakiewicz PL, Rogers CG, Vazina A, Bastian PJ et al (2007) Discrepancy between clinical and pathologi stage: impact on prognosis after radical cystectomy. Eur Unol 51: 137-149, discussion 149.15!

5. Stein JP, Lieskovsky G, Cote R, Groshen S, Feng AC, Boyd S et al (2001) Radical cystectomy in the treatment of invasive bladder cancer: long-4arm results in 1,054 patients. J Clin Oncol 19:666-675

6. Teloh HA (1957) Methods in surgical pathology. Thomas 6. Teloh HA (1957) Methods in sur
Chapter 26, Springfield, IL, pp $80-82$

7. Lopez-Beltran A, Bassi PF, Pavone-Macaluso M, Montironi R (2004) Handling and pathology reporting of specimens with carcinoma of the urinary bladder, ureter, and renal pelvis. A joint proposal of the European Society of Uropathology and the Uropathology Working Group. Virchows Arch 445:103-110

8. (2011) Rosai and Ackerman's surgical pathology, 10th odn. In: Rosai J. Mosby, St. Louis, MO, pp 2913-2914

9. van Dijk PR, Plocg M, Aben KK, Weijerman PC, Karthaus HF, van Berkel JT et al (2011) Downstaging of TURBT-based muscle 
imvasive bladder cancer by radical cystectoeny predicts better surviv. al. ISRN Urol $2011: 458930$

10. Hautmann RE, de Petriconi RC, Pfiffer C, Volkmer BG (2012) Radical cystectoeny for urothelial carcinoma of the bladder without neoadjuvant or adjuvant therapy: long-term results in 1100 patients. Eur Urol 61:1039-1047

11. Hermann E, Stoter E, van Ophoven A, Bierer S, Bolenz C, Hertle L et al (2008) The prognostic impact of pelvic lymph node metastasis and lymphovascular imasion on bladder cancer. Int J Urol 15:607611

12. Madershacher S, Hochreiter W, Burkhard F, Thalmann GN, Danuser H, Markwalder R et al (2003) Radical cystectomy for bladder cancer today-a homogenevus series without neoadjuvant therapy. J Clin Oncol $21: 690-696$

13. Mallen Mateo E, Gil Martinez P, Gil Sanz MJ, Sancho Serrano C, Pascual Regueriro D, Rioja Sanz LA (2006) Stage pT0 bladder tumos after radical cystectomy: a revicw of our series. Actas Urol Esp 30:763-771

14. May M, Bastian PJ, Burger M, Bolenz C, Trojan L, Hermmann E et al (2011) Multicenter evaluation of the prognostic value of pT0 stage after radical cystectomy due to urothelial carcinoma of the bladder. BJU Int 108:E278-E283

15. Roupret M, Drouin SJ, Larre S, Neuzillet Y, Bomo H, Hitier M at al (2011) Oncologic outcomes and survival in pT0 tumors after radical cystectomy in patients without neodijuvant chemotherapy: results from a large multicentre collaborative study. Amn Surg Onool 18 $3832-3838$

16. Rink M, Ehdaie B, Cha EK, Green DA, Karnkiewicz PI, Babjuk M et al (2012) Stagespecific impact of tumor location on cocologic outcomes in patients with upper and lower tract urothelial carcinoma following radical surgery. Eur Urol 62(4):677-684

17. Rodriguez Faka O, Palou J, Rosales A, Broda A, Algaba F, Undancta $G$ et al (2011) Clinical predictive factors of poor outcome in patients with stage $\mathrm{pTO}$ disense at ratical cystoctomy. J Urol 186:442-447

18. Takahashi A, Tsukamoto T, Tobisa K, Shinohara N, Sato K, Tomita Yet al (2004) Radical cystectomy for invasive bladder cancer. results of malti-institutional pooled analysis. Jpa J Clin Oncol 34:14-19

19. Tilki D, Reich O, Svatck RS, Karakicwicz PI, Kassouf W, Novara G et al (2010) Chancteristics and outcomes of patients with clinical carcinoma in situ only treated with radical cystectomy: an intema. tional study of 243 patients. J Urol 183:1757-1763
20. Tollefson MK, Boorjian SA, Farmer SA, Frank I (2012) Downstaging to non-invasive urothelial carcinoma is associsted with improved outcome following radical cystectomy for patients with cT2 disease. World J Urol 3Q(6):795-799

21. Vickers A, Cronin AM, Kattan MW, Gonen M, Scardino PT, Milowsky MI et al (2009) Clinical benefits of a multivariate prediction model for bladder cancer. a decision analytic appooach. Cancer $115-5460-5469$

22. Yu RJ, Stein JP, Cai J, Miranda G, Groshen S, Skinner DG (2006) Superficial (pT2a) and deep (pT2b) muscle invasion in puthological staging of bladder cancer following rodical cystectoeny. J Urol 176 : $493-498$, discussion 498.499

23. Greene FL, Page DL, Flemming ID et al (2002) American joint committee on cancer staging manul. Springer, New York

24. Soto EA, Friedell GH, Tiltman AJ (1977) Bladder cancer as seen in giant Hissologic sections. Cancer 39:447-455

25. Jewett $\mathrm{HJ}$ (1977) The historical development of the staging of bladder tumors personal reminiscences. Urol Surv 27:37-40

26. Boudreaur KJ Jr, Clark PE, Lowrance WT, Rumohr JA, Barocas DA Coolsson MS et al (2009) Compariscen of american joint committee on cancer pathological stage $\mathrm{T} 2 \mathrm{a}$ versus $\mathrm{T} 2 \mathrm{~b}$ urothelial carcinome analysis of patient outcomes in organ confined bladder cancer. JUrol 181:540-545, discussion 546

27. Tilki D, Reich O, Kankiewicz PL, Novara G, Kassouf W, Engun S et al (2010) Validation of the ANCC TNM substaging of $\mathrm{pT} 2$ bladder cancer: deep muscle invasion is associated with significantly worse outoome, Fur Urol 58:112-117

28. Scosyrev E, Yao J, Messing E (2010) Microscopic invasion of perivesical fat by urothelial carcinoma: implications for prognosis and pathology practice. Urology 76-908-913, discussicen 914

29. Donat SM, Genega EM, Herr HW, Reuter VE (2001) Mechanisms of prostatic stromal invasion in patients with bladder canoer: clinical significance. J Urol 166:1117-1120

30. Shen SS, Lemer SP, Muerrinoglu B, Truong LD, Amiel G, Whecler TM (2006) Prostatic imvolvement by transitional cell carcinoma in patients with bladder cancer and its prognostic significance. Hum Patients with bhad 37:726-734

31. Montironi R, Cheng L, Mazrucchelli R, Scarpelli M, Kirkali Z, Montorsi F et al (2009) Critical evaluation of the prostate from cystoprostatectomies for bladder cancer: insights from a complets sampling with the whole mount technique. Eur Urol 55:1305-1309 
Publication III. 


\title{
What can be more prognostic than the pTNM category assessed on radical cystectomy specimens?
}

\author{
Farkas Sükösd ${ }^{1}$ + Béla Iványi ${ }^{1}$ + László Pajor ${ }^{1}$
}

Received: 29 July 2015/Revised: 4 August 2015/Accepted 11 August 2015/Published anline: 23 August 2015

C) Springer-Verlag Berlin Heidelberg 2015

Sir,

The ideal way to compare methods of macroscopic examination would be to examine the same samples twice independently. However, once a radical cystectomy specimen has been completely embedded, alternative methods cannot be investigated because no material remains. Gaisa et al. elegantly cut this Gordian knot with their "virtual superimposed approach." They embedded the whole cystectomy specimen into small blocks and then extracted the block data that would have been used for standard assessment on the basis of specimen photographs and compared them. As concems tumor stage, they did not find any significant differences between the two approaches [1].

Another novelty they introduced is the pTsum category. They determined tumor stage on the cystectomy specimen, but in cases with previous TUR-B and no or minimal residual tumor, the final tumor stage was defined as the sum of the TUR-B and the cystectomy specimen. Theoretically, it is possible that the pTsum category is prognostically more informative than the $\mathrm{pT}$ as defined in the standard TNM system. However, in their paper, the Kaplan-Meier curve of overall survival in relation to pTsum (Fig. $4 \mathrm{~A}$ in the publication) suggests that the death rate of patients with pT1 tumors is higher than that of patients with pT2 tumors after a 20-month follow-up. We consider that introduction of the pTsum category is not in agreement with the authors' intended study design

Darkas Säkösd

sukosd.farkasigmed.woseged. hu

University of Szeged, Szeged, Hungary in terms of comparing the standard specimen sampling with whole specimen embedding relative to standard pTNM. A significant degree of uncertainty is introduced with unknown TUR-B results. How was "minimal residual tumor" defined, which TUR-B stage had more impact than pTNM on the cystectomy specimen, and what is the advantage of having an early TUR-B stage? Why was the traditional staging system not used? It is rather disturbing that the authors wrote about stage but studied stage only with a self-created pTsum system.

Since 2008 , we have examined 315 cystectomy specimens and used whole-organ embedding approach with commercially available macroblocks as part of the daily routine. We have reported stage distribution of the first 138 cases and compared this with data obtained by standard methods on 15,586 literature cases [2]. Our method highly reliably mirrors the averages of published data, with as only exception that we identified a significantly higher proportion of $\mathrm{pT} 4$ cases. When pTsum stages are compared with our data and literature-based data, two differences emerge (Fig. 1). First, pT1-pT3 stages are more frequent in the series by Gaisa et al. than in ours. This may be due to the pTsum category, with TUR-B stages increasing the case number of higher stage cases at the expense of lower stages. Second, Gaisa et al. found nearly the same proportion of pT4 cases as the average we generated from literature data. In contrast, our series reveals a significantly higher rate of this advanced category because our base block approach, in which the prostatebladder boundary is processed in 12 radial cuts, detects prostate involvement more precisely.

We therefore regard the whole-organ embedding approach as the gold standard in the assessment of the pTNM category and provide prognostically significant histopathological parameters in radical cystectomy specimens. 
Publication IV. 


\title{
Papillary renal cell carcinoma embedded in an oncocytoma: Case report of a rare combined tumour of the kidney
}

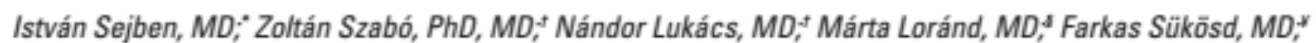 \\ Gábor Cserni, PhD, MD, DSc ${ }^{*}$
}

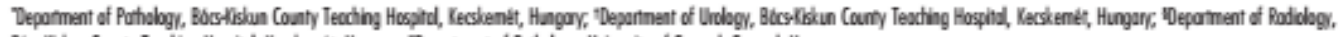

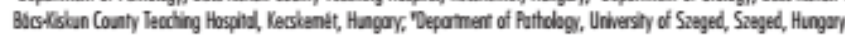

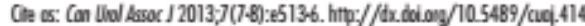
Pullistied onla on July 2, 2013.

\section{Abstract}

An asymptomatic $1 . \mathrm{cm}$ large papillary renal cell carcinoma (RCC) embedded in a $3.5-\mathrm{cm}$ large oncocytoma was diagnosed and

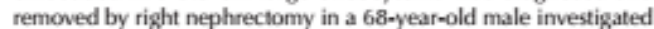
for the abdominal symptoms associated with cholelithiasis. The papillary RCC displayed positive immunohistochemical stainings with cytokeratin 7, alpha-methylacyl-CoA racemase and vimentin and was negative for the E-cadherin and $\mathrm{CD} 117$ immunostains, whereas the oncocytoma part showed opposite staining patterns. No gains of chromosomes 7 and 17 or loss of chromosome $Y$ was detected in the papillary carcinoma by fluorescent in situ hybridization with centromeric enumeration probes. This finding is in keeping with the morphologic diagnosis of type 2 papillary RCC reported to have lower rates of these characteristic chromosomal changes. The combination of papillary RCC and oncocytoma, two tumours of different postulated origin, is extremely rare. It may represent a simple coincidence, but 2 previous cases and our current one share a few features, including the intimate embedment of the papillary RCC in the oncocytoma, the small size of the RCC and the old age of the patients. This case raises the point that renal oncocytomas can contain a hidden malignant tumour.

\section{Introduction}

Renal cell neoplasms are supposed to derive from or show differentiation toward different parts of the renal epithelium, as highlighted by immunohistochemical staining patterns and differential expression of some marker proteins. ${ }^{1-3}$ There are reports on renal tumours with hybrid features between chromophobe renal cell carcinoma (RCC) and oncocytoma, both thought to arise from the distal tubular epithelium. ${ }^{4}$ Sometimes RCC arises within an oncocytoma. ${ }^{3}$ However, the combination of oncocytoma and papillary RCC, 2 renal neoplasms of different origin, is very rare. ${ }^{67}$ We present a case of an unusual combination of these 2 tumours, a papillary RCC buried in an oncocytoma.

\section{Case report}

A 68-year-old male with long-standing hypertension was admitted to our hospital because of right upper abdominal pain. Abdominal ultrasound and computerized tomography (CT) revealed a thick-walled gallbladder with common bile duct stones and a 4-cm mass in the upper pole of the right kidney (Fig. 1). The clinical diagnosis of choledocholithiasis associated with acute cholecystitis and a renal tumour were established. After endoscopic sphincterotomy, the symptoms related to the common bile duct stone vanished and the patient underwent right nephrectomy.

The nephrectomy specimen was fixed in $10 \%$ neutral buffered formalin for 36 hours. We embedded 3-mm-thick representative tissue sections in paraffin wax and sections of 4 to $5 \mu \mathrm{m}$ were cut and stained with hematoxylin and eosin (H\&E) for light microscopy. The primary antibodies used for immunohistochemistry are shown in Table 1.

\section{Results}

The parenchymal tumour in the nephrectomy specimen was circumscribed, homogeneous, yellowish-brown and measured $35 \times 35 \times 30 \mathrm{~mm}$. Microscopically, all but one slide showed polygonal cells forming nests and tubules that had abundant eosinophilic, granular cytoplasm and uniform, round central nuclei. Neither mitotic figures nor clear cell areas were detected. The tumour morphology was in keeping with the diagnosis of an oncocytoma. A papillary lesion with papillary and tubulopapillary structures measuring $1 \mathrm{~cm}$ in diameter was identified microscopically within this tumour. Eosinophilic, granular, but less voluminous cytoplasm and focal nuclear pseudostratification characterized this area. Cytoplasmic clearing was identified focally. Foamy macrophages and rare psammoma bodies occurred in the core of the papillae. The nuclei were generally of low grade, but areas with larger nuclear to cytoplasmic ratio and nucleoli visible at medium power magnification were also present resulting in a Fuhrman grade 2 overall (Fig. 2). The papillary carcinoma was present in a single block only, and attempts 


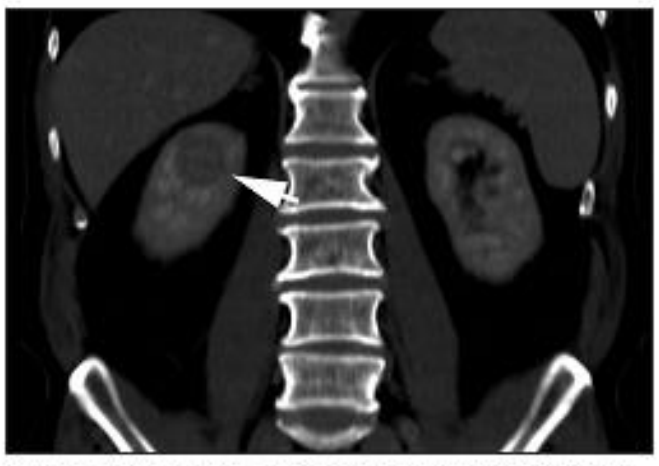

Fig. 1. Localization of the tumour on computed tomagraphy scan. The arrow shows the circumscribed tamour in the upper part of the right kidney.

to identify any remnants of it grossly and in further tumour blocks taken failed.

The oncocytoma part showed diffuse positivity for E-cadherin and weak positivity for CD117, whereas it was negative for vimentin and alpha-methylacyl-CoA racemase (AMACR). It showed very focal cytokeratin 7 (CKT) positivity limited to small areas with more pleomorphic nuclei, which is a recognized feature of some oncocytomas. The papillary area was positive for CK7, AMACR and vimentin, but negative for CD117 and E-cadherin (Fig. 3). Neither parts were

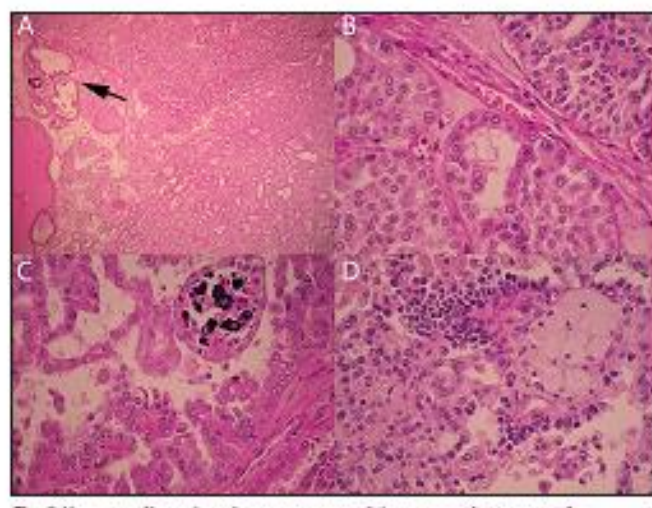

Fig. 2 Hemataxylin and eogin appearance of the composite tumour. A: Papillary renal cell carcinoma (RCC) (upper triangular area) separated from the oncocytoma by a thin pseudocapsule but also showing an irregular extension into it, with psammomatous calcification (arrow) (*100). B: Part of the pseudacapsale separating the 2 tumour camponents. Note the cytoplasmic eosinophilia in both components: the low grade noclei (in this fieid) and the higher nuclear to cytoplssmic ratio in the papillary ACC component (upper part) in comparison with the ancocytoma (lower part) (*400). C. Psammamatous calcification, some nuclear pseudostratification and higher grade noclei in this area of the papilary BCC (6.4006. D: Foamy macrophages in a papillary core in the ACC $(x 400)$.

\begin{tabular}{|c|c|c|c|}
\hline & Manufacturer & Clone number & Dilution \\
\hline CD10 & Cell Marque & $56 \mathrm{C} 6$ & 1.50 \\
\hline $0 \% 7$ & Dako & OV-T. 12/30 & RTU \\
\hline AMACR & Dako & $13 \mathrm{H} 4$ & RTU \\
\hline CD117 & Dako & polyclonal & 180 \\
\hline E-eadherin & Nowocastra & 3685 & 1240 \\
\hline vimentin & Dako & VIM 384 & RTU \\
\hline synaptophysin & Cell Marque & polyclonal & RTU \\
\hline chromogranin A & Cell Marque & LK2H10 & RTU \\
\hline RTu: ready to une & & & \\
\hline
\end{tabular}

stained with CD10, chromogranin A and synaptophysin. Considering the size, the structure of the lesions and their immunohistochemical staining patterns, the diagnosis of type 2 papillary RCC in an oncocytoma was made.

A fluorescent in situ hybridization (FISH) assay was used to assess the numbers of chromosomes 7, 17 and Y, according to the manufacturer's instructions (Cytocell Ltd, Cambridge, UK). The chromosome enumeration probes hybridizing to the centromere of the relevant chromosomes (LPE007R, Alpha satellite 7 Red; LPE017R, Alpha satellite 17 Red; LPEOYcR, Alpha satellite $Y$ Red) were labelled with spectrum red. The results were evaluated with a ZEISS Axio Imager Z2 microscope. Chromosome copy numbers were counted in 20 cells for each assay, and values of signal/cell ratio greater than 2.8 were defined as trisomy. The FISH assays demonstrated no gains of chromosomes 7 or 17, and no loss of chromosome Y. The patient did not receive adjuvant therapy. The followup was short, but he is alive without any signs of recurrence or metastasis 8 months after nephrectomy.

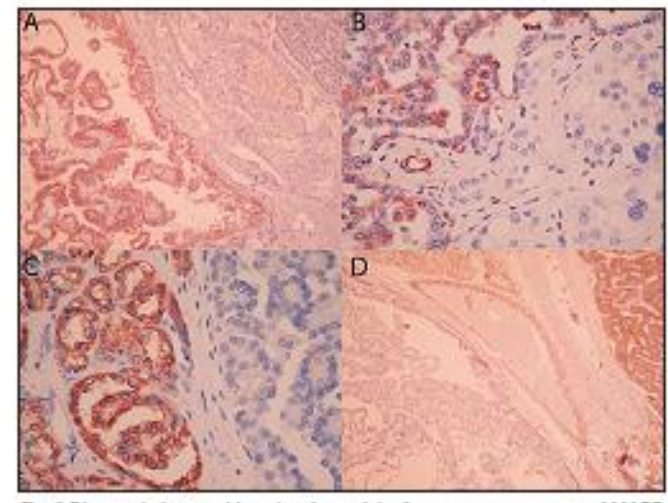

Fig. 3 Diagnostic immunohistochemistry of the 2 tumours components; AMACR (A), vimentin $(B)$ and $C X]$ (C) positivity in the papillary RCC (letef) in opposition with the negativity for these stains in the oncorytoma (righti). E-cadherin displayed an opposite staining pattern (D). (A and D. $\times 100 ; \mathrm{B}$ and $\mathrm{C} \times \times 400$ ) 


\section{Discussion}

In the 2004 WHO classification of kidney tumours, oncocytoma is considered a benign neoplasm. It is characterized by eosinophilic granular large cells forming diffuse sheets and tubules in an oedematous stroma without papillary or clear cell areas." Immunohistochemically, oncocytomas exhibit positivity for E-cadherin and CD117, and negativity or focal positivity for CK7, AMACR and CD10, ${ }^{1,9}$ It is also recognized that oncocytomas can occur in Birt-Hogg-Dube syndrome, a rare autosomal dominant condition. ${ }^{10}$

Papillary RCC accounts for $10 \%$ of RCCs. Although size criteria of diagnosis always require caution, they are stated to be larger than $5 \mathrm{~mm}$ as opposed to papillary adenoma. ${ }^{\mathrm{s}}$ Two subtypes are recognized. Type 1 tumours have papillae covered by a single layer of small uniform cells. In type 2 tumours, the cells covering the papillae are pseudostratified with eosinophilic cytoplasm and are usually of higher nuclear grade than type 1 papillary carcinomas. Immunohistochemically, papillary RCCs usually show positivity for CK7, AMACR, CD10 and negativity for CD117, E-cadherin. 19,11

Although oncocytoma and RCC are separate entities, they can coexist in the same or the contralateral kidney. Chromophobe RCC and oncocytoma are suspected to be closely related and are thought to show a similar distal tubular phenotype, ${ }^{1-3}$ therefore their coexistence is not very surprising. However, oncocytomas and papillary RCCs originate from different cells, and the presence of a papillary RCC within an oncocytoma is extremely rare. We were only able to identify 2 reports of this coexistence. ${ }^{67}$ The first of a 75-year-old male whose type I papillary RCC of $7 \mathrm{~mm}$ was embedded in an oncocytoma measuring $1.5 \mathrm{~cm}$ in diameter. The papillary tumour in this case was easily identifiable, as it was clearly delineated and obviously different from the surrounding oncocytoma on H\&E stained sections. Unlike in our case, the cells of the papillary neoplasm displayed trisomy of chromosome 7.6 The second case occurred in a 73-year-old female and consisted of a 1.5-mm diameter type II papillary RCC in a 36-mm diameter oncocytoma. No chromosomal copy numbers were analyzed, but the typical morphology and immunohistochemistry confirmed the diagnosis ${ }^{7}$ Both cases were treated with partial nephrectomy,

Our diagnosis of a combined renal tumour consisting of a papillary RCC in an oncocytoma was established on microscopic morphological features and immunohistochemistry. In some areas, the tumours were clearly distinct from each other, but at other foci the 2 tumours merged and showed a diagnostically challenging morphology. Immunostains were of great help in distinguishing the 2 components. Gains of chromosomes 7, 17 and loss of chromosome $Y$ have been described as characteristic of papillary renal neoplasms, ${ }^{12}$ and only very rare tumours were reported to lack these marker changes. "The centromeric probes identified none of the characteristic chromosomal changes, in keeping with their lower incidence in type 2 papillary RCC. ${ }^{14}$

According to the current trends in urology, small renal masses $(\mathrm{s} 4 \mathrm{~cm})$ are often treated by ablative therapies or active surveillance. Prior to such therapeutic approaches, renal biopsy should be performed to establish a histological diagnosis. ${ }^{15}$ Image-guided percutaneous core needle biopsy of renal masses has more than $90 \%$ sensitivity for the detection of malignancy. ${ }^{14}$ However, combined/hybrid tumours consisting of benign and malignant areas can be misdiagnosed, because the biopsy may miss either tumour component or the other. Oncocytomas may sometimes harbour a malignant tumour, especially chromophobe RCC, or as in our case another malignancy. 17 This should be considered when biopsy is used to direct management.

\section{Conclusion}

Our literature review identified that papillary RCCs arising in, or embedded in, an oncocytoma are definitely rare. Although the intimate relationship of the 2 tumors would suggest some causal relationship, the rarity of this combination, the different postulated origins of the 2 components would make it more likely to represent coincidence. Of the 3 papillary RCCs, 2 were type 2 . All were minute pT1 a carcinomas occurring in elderly patients over 65 , and although no information on follow-up was published in previous reports, ${ }^{6,7}$ the reported prognostic features were rather favourable. Partial nephrectomy was the surgical treatment for the previously reported cases, but nephron-sparing surgery was not considered in our current case because the 4-cm tumour was close to the renal hilum and the diagnosis of oncocytoma was not considered preoperatively. Biopsies from combined tumours like this one can pose diagnostic challenges to urologists and pathologists.

Competing interests None dedard.

This poper hes been peervedewad.

\section{Referentes}

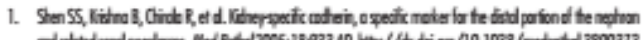

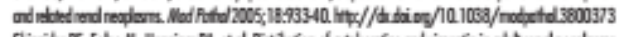

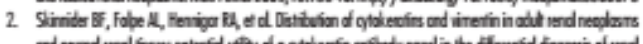

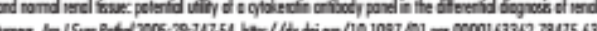

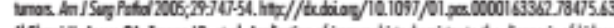

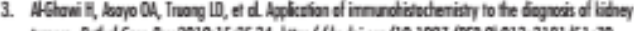

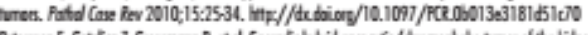

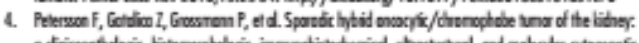

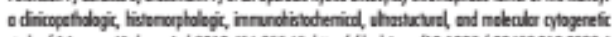

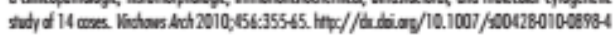


Sejben et al.

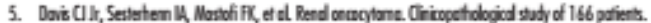
J loyen Fattal 191;1:41:52.

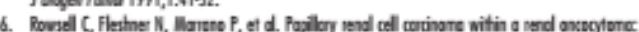

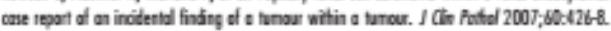

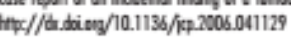

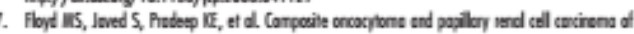

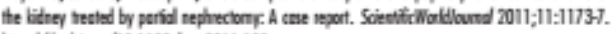

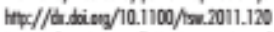

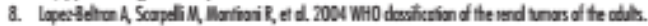

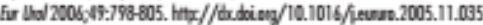

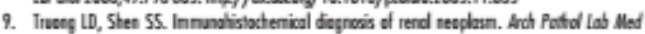
2011; 135:-92-109.

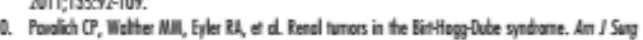

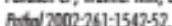

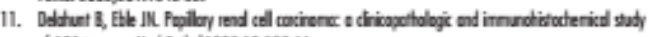
of 105 turors Mad fattel 1997; 10-537-46.

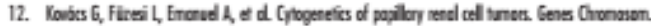

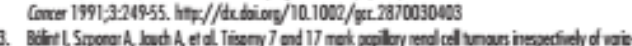

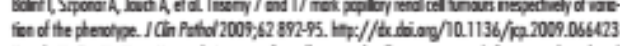

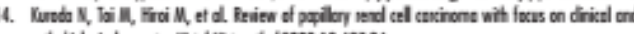

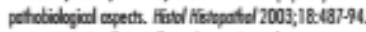

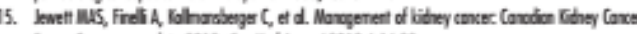

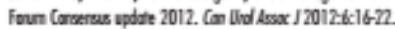

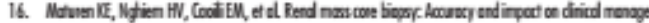

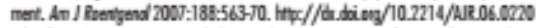

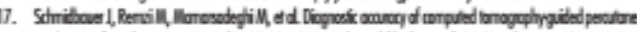

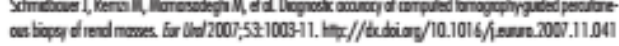

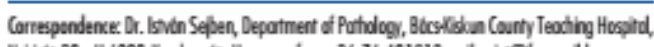

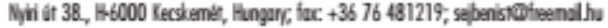


Lecture I. 
A Magyar Patológusok Társaságának és a Nemzetközi Patológiai Akadémia (IAP) Magyar Divíziójának Kongresszusa Gyula, 1998. angusztus 26-29.
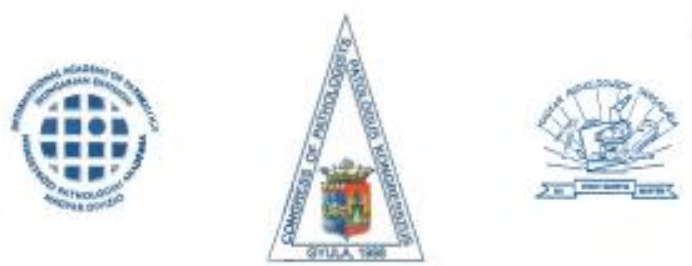

\section{Congress}

of the Hungarian Society of Pathologists and of the Hungarian Division of the International Academy of Pathology August 26-29, 1998 - Gyula, Hungary

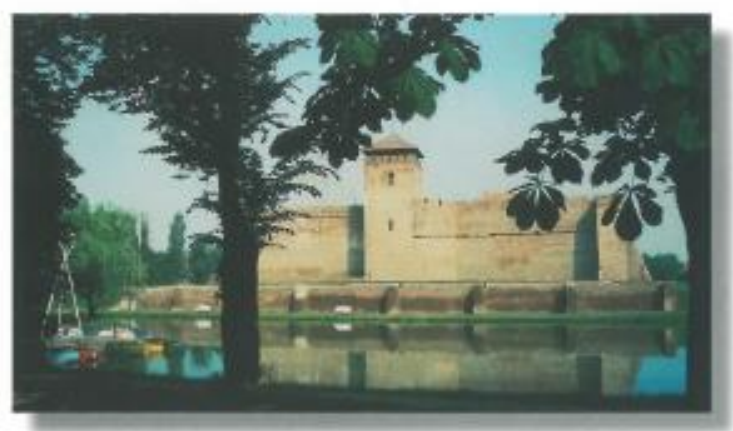


Papillaris vesetumor in situ hybridizációs vizsgálata In situ hybridization study of papillary kidney tumors

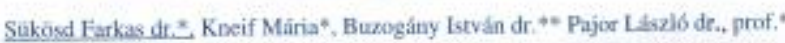

spécsi Onostudományi Egyetem, Patológiai Intézet.

**Pécsi Oryostudományi Egyetem, Urolbgiai Klinika, Ples

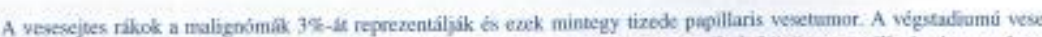

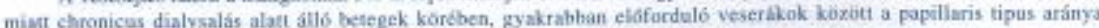

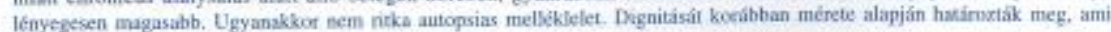

\section{Bejelentett elöadások / Oral Presentations}

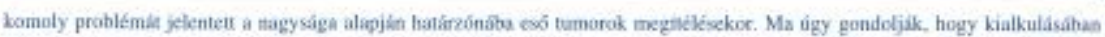

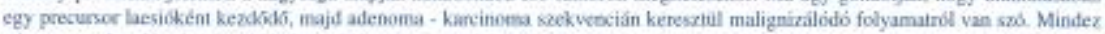

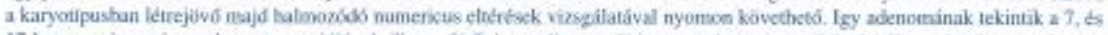

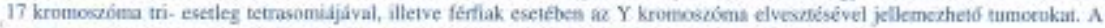

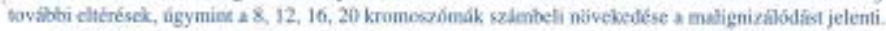

Celunk volt az in situ hybridiziciós technika alkalmazkskval szolid tumsorbol seármazó inferfasisal magok numerikus. kromoszómilis eltéréscinek meghatínarása.

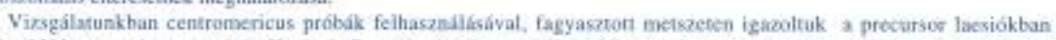

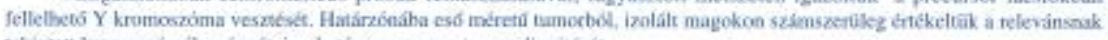
nekintell kromescómik arányát, igy hatínceva meg a tumor digzitását.

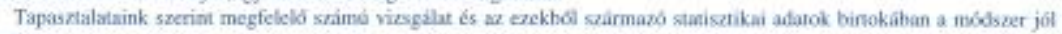

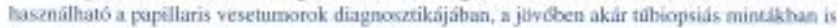


Lecture II. 


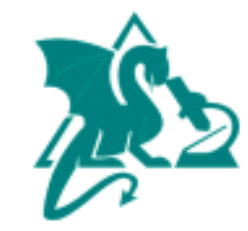

\section{3rd Pannonia Congress of Pathology}

May 15-17, 2014, Bled, SLOVENIA

\section{Programme}

\section{Wednesday, May 14, 2014}

08.00-18.00 Registration

PRECONGRESS MEETING / WG PULMONARY PATHOLOGY

Chairpersons: Helmut Popper (Austria), Ulrike Gruber- Mösenbacher (Austria)

$16.00-19.00$

20.00

Dinner for the Faculty and PCP Board members 
KEYNOTE LECTURE

Chairperson: Metka Volavšek (Slovenia)

14.15-14.45 Pathology of the gastrointestinal tract: new developments Han van Krieken (Netherlands)

PLENARY SESSION / UROPATHOLOGY

Chairpersons: Jera Jeruc (Slovenia), Bożo Krušlin (Croatia)

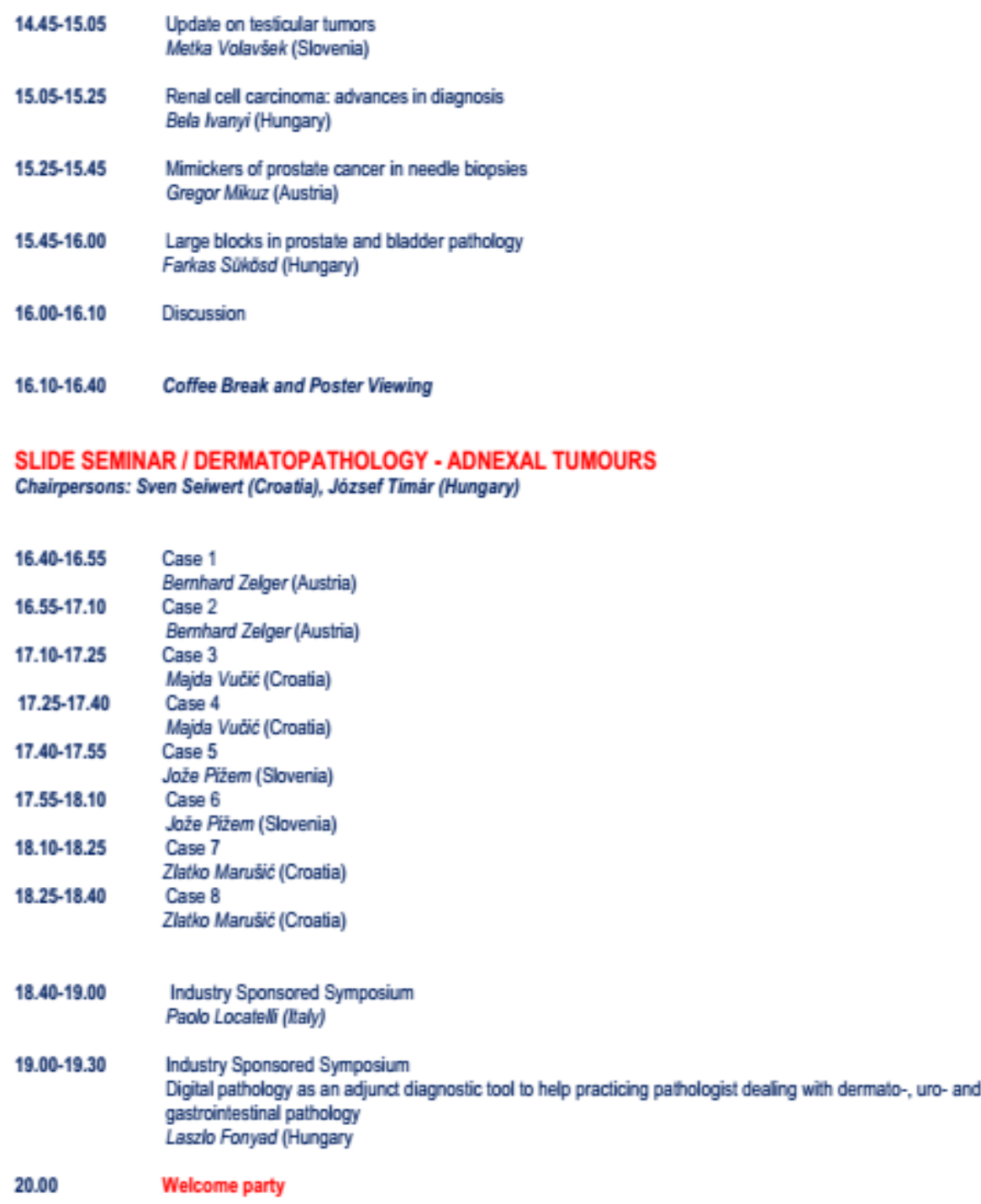

20.00

Welcome party 
Lecture III. 


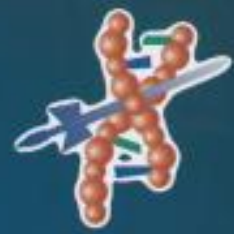

\section{5 第八届世界癌症大会} BIT's $8^{\text {th }}$ Annual World Cancer Congress-2015

主题：贯通研究与实践 Theme: Bridging Research and Practice

时间: 2015年5月15-17日

Date: May 15-17, 2015

地点: 中国北京国际会议中心

Venue: Beijing International Convention Center, China

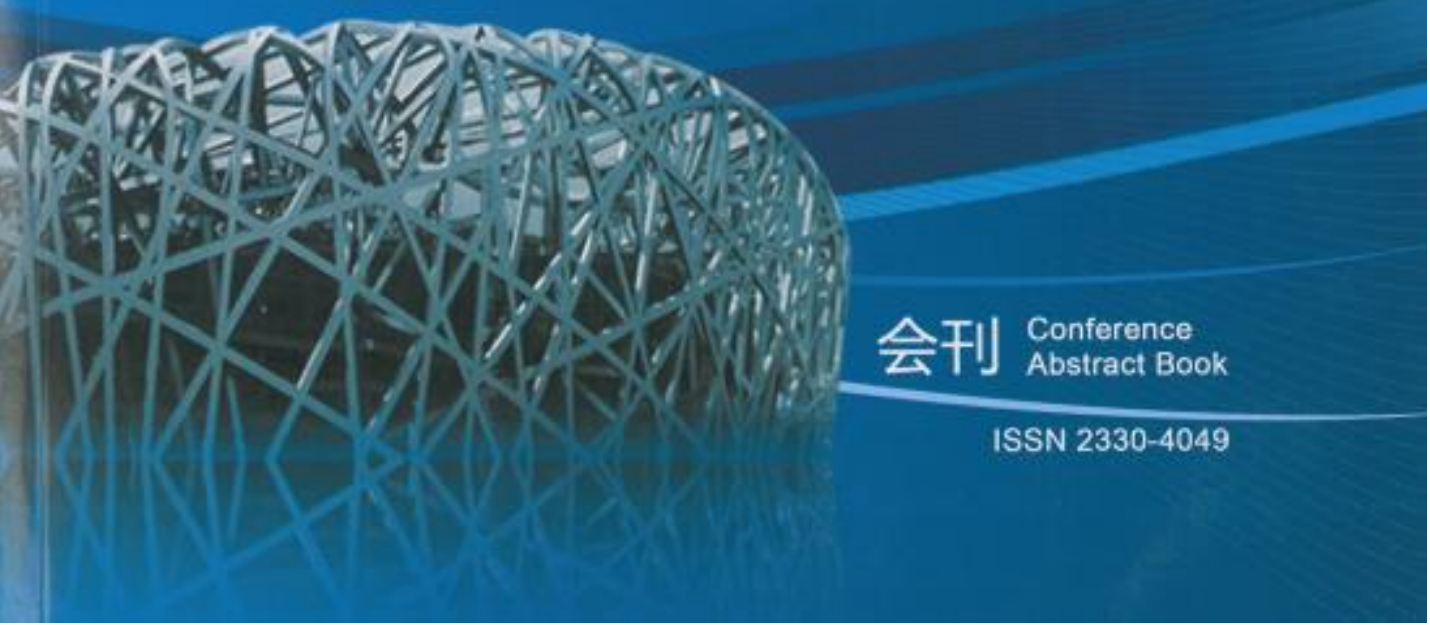




\section{Title: Accurate Determination of the Pathological Stage with Gross Dissection Protocol for Radical Cystectomy in Daily Routine Diagnostics}

Dr. Farkas Säkösd*, Bela Tvingl, and Lészló Pajor

Head

Laboratory of Molecular Pathology

Unisersity of Szeged

Hungary

\section{Abstract}

The current protocol foe reporting urinary bladder cancer in radical cystectomies may exhibit limitations in the diagrostic accuracy, such as the risk for understaging, especially in cases of prostatio involvement. Difficulty exists in the verification of stage p T0 and assessment of surgical margins is suboptimal. Therefore, we developed a daily practice gross dissection protocol (GDPRC) where the radical cystectomies were totally embedded in commercially available macroblock and evaluated histologically. The incidence of pathological stages of our first 138 consecutive samples series was compared with same data of 15586 radical cystectomies. We found a remarkably down stage in the current standard protocol where the difference in pT4 was significant. $(\mathrm{p}=0.0494)$ With our method, only those samples were regarded as pTO in which the granulomatous area and the haemosiderin deposition indicative of the earlier intervention were observable and the entire preparation was fumor-free.

\section{Biograply}

Dr. Farkas Sukōsd now is a Consultant Pathologists, 2003-present: Laboratory of Molecular Pathology Leader (Genetics of solid tumours) Department of Pathology, University of Szeged Medical Faculty, Szeged, Hungary. 2000-2002: Guest Scientist (Microsatellite allele typing on urinary bladder and kidney cancer) Laboratory of Molecular Oncology Ruprecht-Karis University Heidelberg, Heidelberg, Gemany. 1996-2000: SHO in Histopathology Institute of Pathology University Medical School of Pecs, Pees, Hungary.1993-1996; undergraduate instructor (Genetic classification of kidney tumours) Institute of Pathology University Medical School of Pecs, Pecs, Hungary. 


\title{
International Journal of Cancer Therapy and Oncology, Vol 3, No 4 (2015)
}

\author{
Accurate Determination of the Pathological Stage with the Gross \\ Dissection Protocol for Radical Cystectomy (GDPRC) in Daily Routine \\ Diagnostics
}

Farkas Sükösd, Béla Iványi, László Pajor

\begin{abstract}
Purpose: The currently protocol for reporting urinary bladder cancer in radical cystectomies may exhibit limitations in the diagnostic accuracy, such as the risk for understaging, especially of cases in prostatic involvement. Difficulty exists in the verification of stage pT0 and assessment of surgical margins is suboptimal. Eliminate the potential compromises in sampling, we developed a daily practice gross dissection protocol where the radical cystectomies were totally embedded and evaluated histologically in whole-mount sections.
\end{abstract}

Methods: Here were reported the first 138 consecutive specimens from 99 men and 39 women from 2008 to the first quarter of 2012 inclusive; 9.2 macroblocks and 14 standard blocks were examined on overage. The incidence of cancer stages of our series was compared with the incidence of cancer stages, determined by retrieving the stage data of 15586 radical cystectomies from the literature. The differences were analyzed with the one-sample z-test $(p<0.05)$.

Results: The following values were obtained (the first refers to our series): pT0 8.7\% and $6.1 \%$; pTa $0.7 \%$ and $2.9 \%$; pTis $2.9 \%$ and $6 \%$; pT1 $15.2 \%$ and $15.5 \%$; pT2 $21 \%$ and 23.3\%; pT3 $34.8 \%$ and $34.3 \%$; and pT4 $16.7 \%$ and $11 \%$.

Conclusion: Our findings closely reflected the means of the published statistical data based on a large number of cases. The differences were due to the more detailed processing: the case numbers in groups pTis-pT2 were comparatively low, those in groups pT3-pT4 were higher. The difference found in group pT4 was significant. ( $p=$ 0.0494) With this method only those samples were regarded as pT0 in which the granulomatous area and the haemosiderin deposition indicative of the earlier intervention were observable and the entire preparation was tumor-free. Although our protocol was three times more expensive than the currently used and the reporting time took four hours by identifying all features that can guide postoperative treatment has the monopoly of diagnostic accuracy.

Cite this article as: Sükösd F, Iványi B, Pajor L. Accurate Determination of the Pathological Stage with the Gross Dissection Protocol for Radical Cystectomy (GDPRC) in Daily Routine Diagnostics . Int J Cancer Ther Oncol 2015; 3(4):3407.

[This abstract was presented at the BIT's $8^{\text {th }}$ Annual World Cancer Congress, which was held from May 15-17, 2015 in Beijing, China.] 